\title{
Evaluation of High-Level Waste RECEIVED \\ Vitrification Feed Preparation APR O 11996 Chemistry for an NCAW Simulant, FY 1994: Alternate Flowsheets (DRAFT)
}
H. D. Smith
M. D. Merz
K. D. Wiemers
G. L. Smith

February 1996

Prepared for the U.S. Department of Energy under Contract DE-AC06-76RLO 1830

Pacific Northwest National Laboratory Richland, Washington 99352

Battelle

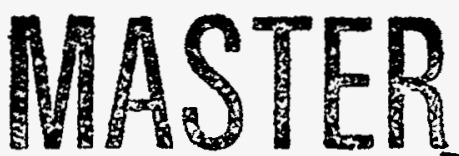




\section{Evaluation of High Level Waste Vitrification Feed Preparation Chemistry for an NCAW Simulant, FY 1994: Alternate Flowsheets (Draft)}
H. D. Smith
M. D. Merz
K. D. Wiemers
G. L. Smith

February 1996

Prepared for

the U.S. Department of Energy

under Contract DE-AC06-76RLO 1830

Pacific Northwest National Laboratory

Richiland, Washington 99352

Reprint of historical document PVTD-C95-02.02K Rev. 0 (Draft), dated September 1995. Data, formanting, and other conventions reflect standards at the original date of printing. Technical peer reviews and editorial reviews may not have been performed. 


\section{DISCLAIMER}

This report was prepared as an account of work sponsored by an agency of the United States Government. Neither the United Statès Government nor any agency thereof, nor Battelle Memorial Institute, nor any of their employees, makes any warranty, express or implied, or assumes any legal liability or responsibility for the accuracy, completeness, or.usefulness of any information, apparatus, product, or process disclosed, or represents that its use would not infringe privately owned rights. Reference herein to any specific commercial product, process, or service by trade name, trademark, manufacturer, or otherwise does not necessarily constitute or imply its endorsement, recommendation, or favoring by the United States Government or any agency thereof, or Battelle Memorial Institute. The views and opinions of authors expressed herein do not necessarily state or reflect those of the United States Government or any agency thereof.

\section{PACIFIC NORTHWEST NATIONAL LABORATORY operated by \\ BATTELLE \\ for the \\ UNITED STATES DEPARTMENT OF ENERGY \\ under Contract DE-AC06-76RLO 1830}

Printed in the United States of America

Available to DOE and DOE contractors from the

Office of Scientific and Technical Information, P.O. Box 62, Oak Ridge, TN 37831; prices available from (615) $576-8401$.

Available to the public from the National Technical Information Service, U.S. Department of Commerce, 5285 Port Royal Rd., Springfield, VA 22161

The document was printed on recycled paper. 
FIGURES $\ldots \ldots \ldots \ldots \ldots \ldots \ldots \ldots \ldots \ldots \ldots \ldots \ldots \ldots \ldots \ldots \ldots \ldots \ldots \ldots$

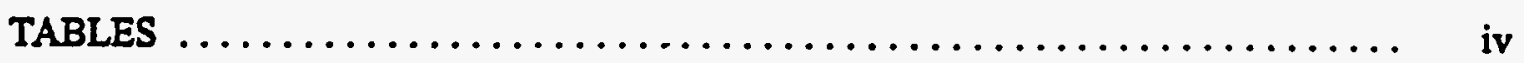

EXECUTTVE SUMMARY $\ldots \ldots \ldots \ldots \ldots \ldots \ldots \ldots \ldots \ldots \ldots \ldots \ldots \ldots$

$1.0 \quad$ INTRODUCTION $\ldots \ldots \ldots \ldots \ldots \ldots \ldots \ldots \ldots \ldots \ldots \ldots \ldots \ldots \ldots \ldots$

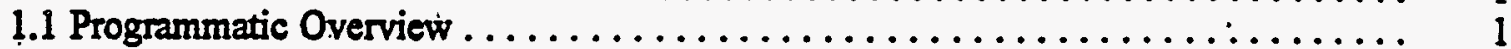

1.2 Altemate Flowsheet Selection Criteria $\ldots \ldots \ldots \ldots \ldots \ldots \ldots \ldots \ldots \ldots \ldots$

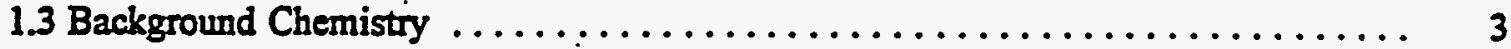

2.0 CONCLUSIONS AND RECOMMENDATIONS $\ldots \ldots \ldots \ldots \ldots \ldots \ldots \ldots \ldots$

3.0 OBJECTIVES $\ldots \ldots \ldots \ldots \ldots \ldots \ldots \ldots \ldots \ldots \ldots \ldots \ldots \ldots \ldots \ldots \ldots$

$4.0 \quad$ APPROACH $\ldots \ldots \ldots \ldots \ldots \ldots \ldots \ldots \ldots \ldots \ldots \ldots \ldots \ldots \ldots \ldots \ldots \ldots$

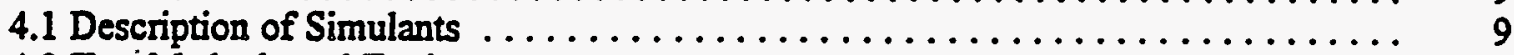

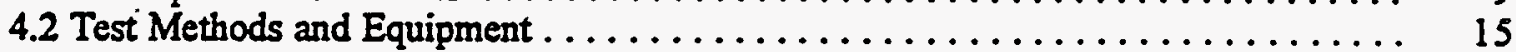

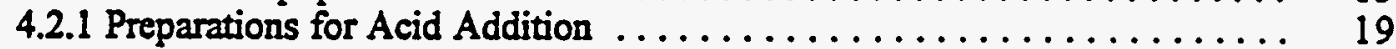

4.2 .2 Acid Addition $\ldots \ldots \ldots \ldots \ldots \ldots \ldots \ldots \ldots \ldots \ldots \ldots \ldots \ldots \ldots$

4.2.3 Hold Period at the Acid Addition Temperature ................ 20

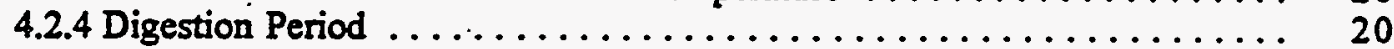

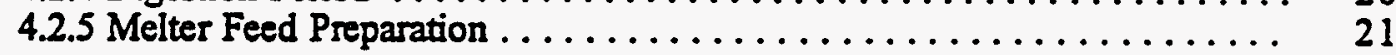

$5.0 \quad$ RESULTS AND DISCUSSION $\ldots \ldots \ldots \ldots \ldots \ldots \ldots \ldots \ldots \ldots \ldots \ldots \ldots \ldots \ldots \ldots$

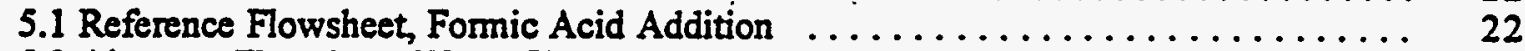

5.2 Altemate Flowsheet, Waste Slurry Results . . . . . . . . . . . . . . . . . . 29

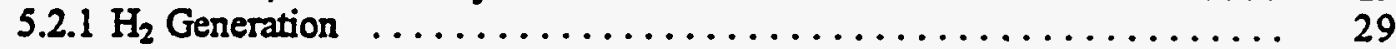

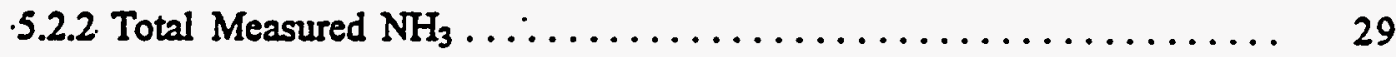

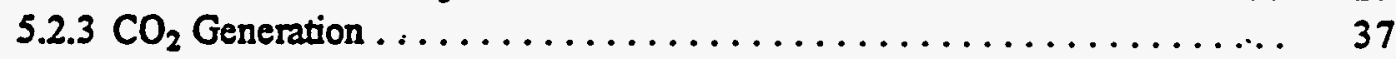

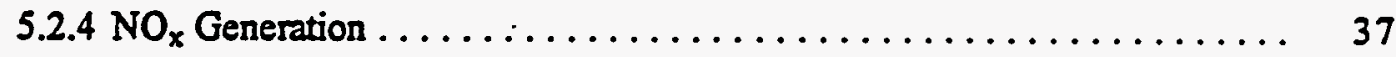

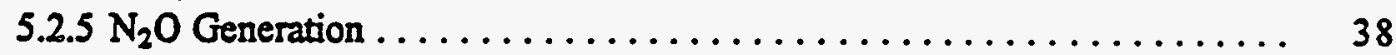

5.3 Altemate Flowsheet, Melter Feed Slurry Results . . . . . . . . . . . 38

$6.0 \quad$ REFERENCES $\ldots \ldots \ldots \ldots \ldots \ldots \ldots \ldots \ldots \ldots \ldots \ldots \ldots \ldots \ldots \ldots \ldots \ldots \ldots$ 


\section{FIGURES}

Figure 4.2.1 - Schematic of the Laboratory-Scale Reaction Vessel Used for Waste Slurry Simulant Processing Tests and Melter Feed Preparation . . . . . . . . . . . .

Figure 4.2.2 - Schematic of the Laboratory-Scale Offgas Equipment Configuration for Waste Slurry Simulant Processing Tests and Melter Feed Preparation ... . . . .

Figure 5.1.1 - Baseline Test T94-HCOOHBase-1 Offgas Profiles Covering a Period of 400 Minutes after the Initiation of $\mathrm{HCOOH}$ Addition. Temperature, $\mathrm{pH}$, $\mathrm{CO}_{2}, \mathrm{H}_{2}, \mathrm{NO}_{x}$, and $\mathrm{N}_{2} \mathrm{O}$ profiles are shown $\ldots \ldots \ldots \ldots \ldots \ldots \ldots \ldots$

Figure 5.1.2 - Baseline Test T94-HCOOHBase-2 Offigas Profiles Covering a Period of 400 Minutes after the Initiation of $\mathrm{HCOOH}$ Addition. Temperature, $\mathrm{pH}, \mathrm{CO}_{2}, \mathrm{H}_{2}, \mathrm{NO}_{x}$, and $\mathrm{N}_{2} \mathrm{O}$ profiles are shown $\ldots \ldots \ldots \ldots \ldots \ldots \ldots$

Figure 5.1.3 - Baseline Tests T94-HCOOHBase-3 Offgas Profiles Covering a Period of 450 Minutes after the Initiation of $\mathrm{HCOOH}$ Addition. Temperature, $\mathrm{pH}, \mathrm{CO}_{2}, \mathrm{H}_{2}, \mathrm{NO}_{\mathrm{x}}$, and $\mathrm{N}_{2} \mathrm{O}$ profiles are shown $\ldots \ldots \ldots \ldots \ldots \ldots \ldots \ldots$

Figure 5.1.4 - Composite of the Three Baseline Test Offgas Profiles Illustrating the Observed Reproducibility over the First 300 Minutes after the Initiation of $\mathrm{HCOOH}$ Addition. Temperature, $\mathrm{pH}, \mathrm{CO}_{2}, \mathrm{H}_{2}, \mathrm{NO}_{x}$, and $\mathrm{N}_{2} \mathrm{O}$ profiles

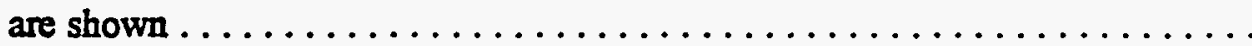

Figure 5.2.1 - Offgas Profiles from Test T94-CITRIC-1 Covering the First 450 Minutes after the Initiation of Citric Acid Addition. Temperature, $\mathrm{pH}, \mathrm{CO}_{2}, \mathrm{NO}_{\mathrm{x}}$, and $\mathrm{N}_{2} \mathrm{O}$ profiles are shown. $\mathrm{No}_{2}$ was detected $\ldots \ldots \ldots \ldots \ldots \ldots \ldots$

Figure 5.2.2 - Offgas Profiles fiom Test T94-GLYCOLIC-1 Covering the First 450 Minutes after the Initiation of Glycolic Acid Addition.

Temperature, $\mathrm{pH}, \mathrm{CO}_{2}, \mathrm{NO}_{x}$, and $\mathrm{N}_{2} \mathrm{O}$ profiles are shown.

$\mathrm{H}_{2}$ was detected but was not plotted.

Figure 5.2.3 - Offgas Profiles from Test T94-LACTIC-1 Covering the First 450 Minutes after the Initiation of Lactic Acid Addition. Temperature, $\mathrm{pH}, \mathrm{CO}_{2}, \mathrm{NO}_{\mathrm{x}}$, and $\mathrm{N}_{2} \mathrm{O}$ profiles are shown. No $\mathrm{H}_{2}$ was detected $\ldots \ldots \ldots \ldots \ldots \ldots$

Figure 5.2.4 - Offgas Profiles from Test T94-OXALIC-1 Covering the First 350 Minutes after the Initiation of Oxalic Acid Addition. Temperature, $\mathrm{pH}, \mathrm{CO}_{2}, \mathrm{NO}_{x}$, and $\mathrm{N}_{2} \mathrm{O}$ profiles are shown. No $\mathrm{H}_{2}$ was detected $\ldots \ldots \ldots \ldots \ldots \ldots$ 


\section{FIGURES (cont.)}

Figure 5.2.5 - Offgas Profiles from Test T94-HNO3-1 Covering the First 300 Minutes after the Initiation of Nitric Acid Addition. Temperature, $\mathrm{pH}_{3} \mathrm{CO}_{2}, \mathrm{NO}_{\mathrm{x}}$,

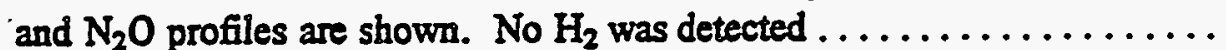

Figure 5.3.1 - Offgas Profiles from Feed Preparation Test T94-FPGLYC-1 Covering the First 250 Minutes after the Initiation of Glycolic Acid Addition. Temperature, $\mathrm{pH}, \mathrm{CO}_{2}, \mathrm{NO}_{x}$ and $\mathrm{N}_{2} \mathrm{O}$ profiles are shown. $\mathrm{H}_{2}$ was detected

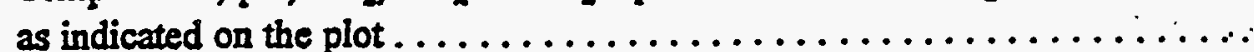

Figure 5.3.2 - Offgas Profiles from Feed Preparation Test T94-FPHNO3-1 Covering the First 300 Minutes after the Initiation of Nitric Acid Addition. Temperature, $\mathrm{pH}, \mathrm{CO}_{2}, \mathrm{NO}_{x}$ and $\mathrm{N}_{2} \mathrm{O}$ profiles are shown. $\mathrm{No}_{2}$ was detected ...........

Figure 5.3.3 - Offgas Profiles from Feed Preparation Test T94-FPOXAL-1 Covering the First 250 Minutes after the Initiation of Oxalic Acid Addition.

Temperature, $\mathrm{pH}, \mathrm{CO}_{2}, \mathrm{NO}_{x}$ and $\mathrm{N}_{2} \mathrm{O}$ profiles are shown.

No $\mathrm{H}_{2}$ was detected 


\section{TABLES}

Table 3.1 - Aiternate Flowsheet Selection Procedure . . . . . . . . . . . . . . . . . 7

Table 3.2 - Test Descriptions and Objectives $\ldots \ldots \ldots \ldots \ldots \ldots \ldots \ldots \ldots \ldots \ldots \ldots$

Table 4.1 - Reference and Simulant NCAW Feed Compositions .............. 10

Table 4.2 - Test Simulants Used for Testing in for the Altemate Flowsheet Evaluation . . . . . 15

Table 5.1.1 - Offas Generated per $130 \mathrm{gWO} / \mathrm{L}$ for the Baseline Tests . . . . . . . . . . . 27

Table 5.1.2 - Peak Offgas Generation Rates per $130 \mathrm{gWO} / \mathrm{L}$ for the Baseline Tests . . . . . . 28

Table 5.2.1 - Offgas Generated per $130 \mathrm{gWO}$ W for the Alternate Flowṣheet Tests . . . . . . . 35

Table 5.2.2 - Peak Offigas Generation Rates per $130 \mathrm{gWO} / \mathrm{L}$ for the Altemate Flowsheet Tests ......................... 36

Table 5.3.1 - Offgas Generated per $130 \mathrm{gWO} / \mathrm{L}$ for the Altemate Flowsheet Melter Feed Preparation Tests ....................... 42

Table 5.3.2 - Peak Offgas Generation Rates per 130gWO/L for the Alternate Flowsheet Melter Feed Preparation Tests ........................... 43 


\section{EXECUTIVE SUMMARY}

High-level radioactive waste stored in tanks at the U.S. Department of Energy's (DOE's) Hanford Site will be pretreated to concentrate radioactive constituents and fed to the vitrification plant. A flowsheet for feed preparation within the vitrification plant (based on the Hanford Waste Vitrification Plant (HWVP) design) called for $\mathrm{HCOOH}$ addition during the feed preparation step to adjust theology and glass redox conditions: However, the potential for generating $\mathrm{H}_{2}$ and $\mathrm{NH}_{3}$ during treatment of high-level waste (HLW) with $\mathrm{HCOOH}$ was identified at Pacific Northwest Laboratory (PNL)! by Wiemers (1988).2 Studies at the University of Georgia, under contract with Savannah River Technology Center (SRTC) (King et al. 1994) and PNL, have verified the catalytic role of noble metals ( $\mathrm{Pd}, \mathrm{Rh}, \mathrm{Ru}$ ), present in the waste, in the generation of $\mathrm{H}_{2}$ and $\mathrm{NH}_{3}$. Both laboratoryscale and pilot-scale studies at SRTC have documented the $\mathrm{H}_{2}$ and $\mathrm{NH}_{3}$ generation phenomena. ${ }^{3}$ Because $\mathrm{H}_{2}$ and $\mathrm{NH}_{3}$ may create hazardous conditions in the vessel vapor space and offgas system of a vitrification plant, reducing the $\mathrm{H}_{2}$ generation rate and the $\mathrm{NH}_{3}$ generation to the lowest possible levels consistent with desired melter feed characteristics is important.

The Fiscal Year 1993 and 1994 studies were conducted with simulated (non-radioactive), pretreated neutralized current acid waste (NCAW). Neutralized current acid waste is a high-level waste originating from the plutonium/uranium extraction (PUREX) plant that has been partially denitrated with sugar, neutralized with $\mathrm{NaOH}$, and is presently stored in double-shell tanks (Peterson et al. 1989). The non-radioactive simulant used for the present study includes all of the trace components found in the waste, or substitutes a chemically similar element for radioactive or very toxic species. The composition and simulant preparation steps were chosen to best simulate the chemical processing characteristics of the actual waste.

This report provides an evaluation of 11 tests conducted in FY 1993 and FY 1994 for the purpose of assessing the effects of modifying flowsheet use of reductants other than formic acid on offgas composition and generation rate, and slumy chemistry. The selection of altemate reductants was based on consideration of practicality for plant operation and potential for process improvement. The evaluation of the effects of altemate reductants was based on the comparison of offgas profiles with a standard profile. The standard profile is viewed as occurring in three stages: carbonate decomposition, nitrite destruction, and $\mathrm{H}_{2}$ plus $\mathrm{NH}_{3}$ formation.

One source of stock NCAW simulants was used for the FY 1993 and FY 1994 tests. The

1 Pacific Northwest Laboratory is operated by Battelle Memorial Institute for the U.S. Department of Energy under Contract DE-AC06-76RLO 1830.

2 Wiemers, K.D. 1990. The Effect of HWVP Feed Nitrate and Carbonate on Glass Redox Adjustment. Technical Report HWVP-900-1.2.2.03.03A, Pacific Northwest Laboratory, Richland, Washington.

3 Hutson, N. 1984. Integrated DWPF Melter System (IDMS) Campaign Report: Hanford Waste Vitrification Plant (HWVP) Process Demonstration, 1994 draft report to Westinghouse Hanford Company, Revision 1. WSRC-TR-92-403, Westinghouse Savannah River Company, Aiken, South Carolina. 
simulant, slurry integrated performance test (SIPT), was prepared on a laboratory scale using a largescale preparation procedure.

Test methods and equipment used during FY 1993-94 were essentially identical to those used during FY.1991 (Wiemers et al. 1993) and FY 1992 (Smith et al. 1995), with the exception that offgas monitoring was done with a different offgas system for the FY 1993-94 tests. The test apparatus consisted of a 2-L Pyrex@4 kettle placed in a temperature-controlled heating mantle. The Pyrex(8) kettle lid was modified to accept a thermocouple, acid addition tube, $\mathrm{pH}$ electrode, $\mathrm{pH}$ automatic temperature compensator, agitator shaf, condenser, sweep gas inlet, slurry sampling/recycle waste stream simulant addition port, and baffle to enhance vertical mixing. A second condenser was added in series to the first condenser connected to the vessel lid. Acid was introduced below the surface of the simulant through a Teflon tube; a peristaltic pump controlled the addition rate. The argon (Ar) sweep gas carried offgases from the reaction vessel plenum through condensers at a rate of -1.95 slpm. . Slurry $\mathrm{pH}$ was collected at $\sim 5$ min intervals on the data acquisition system and recorded manually when other observations were recorded. Slurry and gas temperatures were recorded manually.

The extensive offgas evaluation of the altemate flowsheets showed that all of the candidates produced little or no $\mathrm{NH}_{3}$ and $\mathrm{H}_{2}$. This was predicted by previous University of Georgia studies and the reason the four were selected for this evaluation from a larger group. (Thirteen altemate reductant candidates were screened in a series of laboratory tests by $\mathrm{Dr}$. $\mathrm{R}$ B. King and his associates at the University of Georgia to evaluate the potential for $\mathrm{H}_{2}$ and $\mathrm{NH}_{3}$ generation during treatment of a simplified NCAW simulant.5) However, this left too many candidates to be evaluated and a down selection to oxalic acid, nitric acid, and glycolic acid was made on the basis of redox considerations. The HTM will produce a more reduced melt because of the higher temperatures envolved and make it uncertain what level of reduction will be most beneficial in the melter cold cap during melter operation. Therefore, three alternate flowsheets (oxidizing to reducing) were taken to the meiter feed make up step to see if they would produce a melter feed slurry with both an acceptable rheology for pipe transferes from mixing tanks to the melter and have an acceptable total oxide loading

The theological evaluation showed that the glycolic acid treated feed had acceptable theological properties at a total oxide loading of 400 while the nitric acid feed could not be more concentrated than 380 and display acceptable theology and oxalic acid treated feed could only be concentrated to 280 . Hence oxalic acid was eliminated from further testing and a nitric acid prosessed and a alycolic acid processed feed were recommended for the SSHTM melter tests.

4 Pyrex is registered trademark of Coming Glass Works, Coming, New York.

SR.B. King, N.K. Bhattacharyya, and V. Kumar. December 1993, Monthly Technical Report, "Hanford Waste Vitrification Plant Hydrogen Study: Preliminary Evaluation of Altematives to Formic Acid." Prepared for Pacific Northwest Laboratory under contract number 125770-A-A2. 


\section{Le INTRODUCTION}

\subsection{Programmatic Oyerview}

High-level radioactive waste stored in tanks at the U.S. Department of Energy's (DOE's) Hanford Site will be pretreated to concentrate radioactive constituents and fed to the vitrification plant. A flowsheet for feed preparation within the vitrification plant (based on the Hanford Waste Vitrification Plant (HWVP) design) called for $\mathrm{HCOOH}$ addition during the feed preparation step to adjust rheology and glass redox conditions. However, the potential for generating $\mathrm{H}_{2}$ and $\mathrm{NH}_{3}$ during treatment of high-level waste (HIW) with $\mathrm{HCOOH}$ was identified at Pacific Northwest Laboratory (PNL)1 by Wiemers (1988).2 Studies at the University of Georgia, under contract with Savannah River Technology Center (SRTC) (King et al. 1994) and PNL, have verified the catalytic role of noble metals (Pd, $\cdot \mathrm{Rh}, \mathrm{Ru})$, present in the waste, in the generation of $\mathrm{H}_{2}$ and $\mathrm{NH}_{3}$. Both laboratoryscale and pilot-scale studies at SRTC have documented the $\mathrm{H}_{2}$ and $\mathrm{NH}_{3}$ generation phenomena.3 Because $\mathrm{H}_{2}$ and $\mathrm{NH}_{3}$ may create hazardous conditions in the vessel vapor space and offgas system of a vitrification plant, reducing the $\mathrm{H}_{2}$ generation rate and the $\mathrm{NH}_{3}$ generation to the lowest possible levels consistent with desired melter feed characteristics is important.

High level waste feed preparation flowsheet development was initiated in FY 1994 to select a melter feed preparation process flowsheet for high temperature melter (HTM) testing based on the feed preparation flowsheet that was developed for HWVP. The split acid addition flowsheet (Smith et al., 1994) was one approach that was applied to HWVP feed. This approach allowed the HLW program to build upon the extensive feed preparation flowsheet database developed under the HWVP project. Primary adjustments to the HWVP flowsheet were to the acid adjustment and glass component additions. However, though this approach did reduce the $\mathrm{H} 2$ and $\mathrm{NH} 3$ production, it increased the complexity and preparation time. Therefore, three other potential feed preparation flowsheets were considered as candidates for HTM testing which may be described as follows:

1. No acid adjustment flowsheet

2. No reductant flowsheet

3. Alternate reductant flowsheet

The Fiscal Year 1993 and 1994 studies were conducted with simulated (non-radioactive), pretreated neutralized current acid waste (NCAW). Neutralized current acid waste is a high-level waste originating from the plutonium/uranium extraction (PUREX) plant that has been partially denitrated with sugar, neutralized with $\mathrm{NaOH}$, and is presently stored in double-shell tanks (Peterson et al. 1989). The non-radioactive simulant used for the present study includes all of the trace components found in the waste, or substitutes a chemically similar element for radioactive or very toxic species. The composition and simulant preparation steps were chosen to best simulate the chemical

1 Pacific Northwest Laboratory is operated by Battelle Memorial Institute for the U.S. Department of Energy under Contract DE-AC06-76RLO 1830.

2 Wiemers, K.D. 1990. The Effect of HWVP Feed Nitrate and Carbonate on Glass Redox Adjustment. Technical Report HWVP-900-1.2.2.03.03A, Pacific Northwest Laboratory, Richland, Washington.

3 Hutson, N. 1984. Integrated DWPF Melter System (IDMS) Campaign Report: Hanford Waste Vitrification Plant (HWVP) Process Demonstration, 1994 draft report to Westinghouse Hanford Company, Revision 1. WSRC-TR-92-403, Westinghouse Savannah River Company, Aiken, South Carolina. 
procesșing characteristics of the actual waste.

The altemate/no reductant flowsheets were evaluated on the following basis:

- offgas generation amounts and peak rates (see also, SSHTM Data Package, C95-02.02Y)

- aqueous phase chemistry related to offgas generation and glass redox components

(see also, PVTD-T3C-95-129)

- exothermic reaction potential

- Ineology

- cold cap reactions and glass redox.

The latter three topics are addressed in separate reports, milestone numbers

PVTD-C95-02.02L4 (Sills 1995), PVTD-C94-03.02W5, and PVTD-T3C-95-1296, respectively. The amount of offgas generated, peak gas generation rates and aqueous phase chemistry are addressed in this report.

This report provides an evaluation of 11 tests conducted in FY 1993 and FY 1994 for the purpose of assessing the effects of modifying flowsheet use of reductants other than formic acid on offgas composition and generation rate, and slurry chemistry. The selection of altemate reductants was based on consideration of practicality for plant operation and potential for process improvement. The evaluation of the effects of alternate reductants was based on the comparison of offgas profiles with a standard profile. The standard profile is viewed as occurring in three stages: carbonate decomposition, nitrite destruction, and $\mathrm{H}_{2}$ plus $\mathrm{NH}_{3}$ formation.

In addition, this report includes an appendix that summarizes all the pertinent alternate reductant processing runs made during FY 1993 and FY 1994. Other tests made during FY 1993 were included in an earlier report (Patello et al. 1994). The appendix includes the offgas and analytical chemistry data and a complete description and time line of the tests.

This report summarizes work conducted according to the FY 1993 test plan, Evaluation of Pretreated Neutralized Current Acid Waste (NCAW): Reductant Requirements, Offgas Productivity, and Feed Preparation Reactions 7 and was developed on the basis of the FY 1992 PNL HWVP Technology Development Project Work Plan.8

4 Sills, J.A. 1995. "Evaluation of Hanford High Level Waste Vitrification Chemistry for an NCAW Simulant - Fiscal Year 1994: Potential Exothermic Reactions in the Presence of Formic Acid, Glycolic Acid, and Oxalic Acid." PVTD-C95-02.02L. Pacific Northwest Laboratory, Richland, Washington.

5 Tracey, E.M, P.A. Smith, and K.D. Wiemers. 1994. "Draft Copy: Slurry Characterization Data Package." Pacific Northwest Laboratory, Richland, Washington.

6 Smith, G.L., D.K. Peeler, H.D. Smith, P.A. Smith, E.M. Tracey, and K.D. Wiemers. 1995. "SSHTM Draft Letter Report: Effect of Feed Chemistry on Waste Melter Vitrification Kinetics," Draft Report PVTD-T3C-95-129, Pacific Northwest Laboratory, Richland, Washington.

7 Langowski, M. H., and K. D. Wiemers. 1992. Evaluation of Pretreated Neutralized Current Acid Waste (NCAW): Reductant Requirements, Offgas Productivity and Feed Preparation Reactions. Test Plan PHTD-C92-03.02B, Pacific Northwest Laboratory.

8 FY 1992 Pacific Northwest Laboratory, Hanford Waste Vitrification Plant Technology Development (PHTD) Project Work Plan. PHTD-92-002-Rev. 0, Pacific Northwest Laboratory, Richland, Washington. 


\subsection{Altemate Flowsheet Selection Criteria}

The selection of the melter feed process flowsheets for the SSHTM-1 run are based on: 1) mitigation of $\mathrm{H}_{2}$ and $\mathrm{NH}_{3}$ generation during feed preparation, 2) acceptable feed theological properties, 3) maximum total oxide loading, 4) simplicity, and 5) adaptability to feed compositional variability.

The first downselection criteria for chemical additives employed to adjust glass redox and meiter feed theology was mitigation (ideally elimination) of $\mathrm{H}_{2}$ and $\mathrm{NH}_{3}$ generation. The peak $\mathrm{H}_{2}$ generation rate and total amount of $\mathrm{NH}_{3}$ produced were compared with results observed during $\mathrm{HCOOH}$ reference flowsheet tests.

The values of $15 \mathrm{~Pa}$ and $25 \mathrm{~Pa}$.s for the Bingham yield stress and viscosity, respectively, 'were chosen as the laboratory meological screening data9 based upon communication with PVTD cost account 1.2.2.04.14 (Beckett and Jagoda 1994) and the Hanford Waste Vitrification Technical Data Package10.

Discussions with PVTD cost account 1.2.2.04.14 personnel regarding the SIPT 2/LFCM 8 campaign revealed that a solids loading of approximately $485 \mathrm{~g}$ TO/L for the FY 91 NCAW reference melter feed met the above conditions and was satisfactorily pumped into the melter. This value was also used to screen the laboratory, altemate flowsheet meiter feeds for the small-scale feed preparation system which will be used for SSHTM-1.

Simplicity and adaptability to compositional variability are considered long-term assessment goals. For this study, the simplicity of the tested process flowsheets will be compared with previous reference $\mathrm{HCOOH}$ flowsheet test experience, primarily in a qualitative manner. The description may include such issues as number of process steps and a subjective evaluation of ease of operation. Additional testing will be required to evaluate sensitivity to operation control parameters and feed composition, and process predictability and reliability.

The selection of the specific altemate reductants (citric, glycolic, lactic, oxalic) to be tested was generally based on acidic nature, nontoxicity, cost, and availability. They were selected from a much larger draft list of potential compounds put together by Lambert and Seymour of WHC (1994 communication).

\subsection{Background Chemistry}

The basic aqueous phase chemistry for treatment of an NCAW simulant with formic acid has been addressed in detail by Wiemers et al. 1993, Smith et al. 1995; and King et al. 1994. The reactions identified to date consist primarily of nitrite and carbonate destruction, noble metal catalyzed decomposition of formic acid and reduction of nitrate to ammonia. The reactions are generally observed in three stages as described by Smith et al. 1995.

Stage I

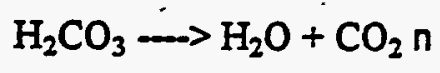

9The theological screening data is taken from a PNL Don't Say It-Write It (DSI) memo: Laboratory Rheological Screening Data to distribution from P. A. Smith dated May 23, 1994.

10Hanford Waste Vitrification Technical Data Package, WHC-SD-HWV-DP-001. 
$\log \left\{\left[\mathrm{H}_{2} \mathrm{CO}_{3}\right] /\left[\mathrm{HCO}_{3}^{-}\right]\right\}=6.45 \cdot \mathrm{pH}$

Stage II

$$
\begin{aligned}
& 3 \mathrm{HNO}_{2} \longrightarrow \mathrm{H}^{+}+\mathrm{NO}_{3}+2 \mathrm{NO} n+\mathrm{H}_{2} \mathrm{O} \\
& \log \left(\left\{\left[\mathrm{HNO}_{2}\right] /\left[\mathrm{NO}_{2}^{-}\right]\right\}=3.35-\mathrm{pH}\right. \\
& 2 \mathrm{FNO}_{2}+2 \mathrm{NaCOOH} \longrightarrow \mathrm{N}_{2} \mathrm{On}+2 \mathrm{CO}_{2} \mathrm{n}+2 \mathrm{NaOH}+\mathrm{H}_{2} \mathrm{O} \\
& 2 \mathrm{HNO}_{2}+\mathrm{NaCOOH} \longrightarrow 2 \mathrm{NO} \mathrm{N}+\mathrm{CO}_{2} \mathrm{n}+\mathrm{NaOH}+2 \mathrm{H}_{2} \mathrm{O}
\end{aligned}
$$

Stage III

$$
\begin{aligned}
& \mathrm{HCOOH} \rightarrow \mathrm{CO}_{2} \mathrm{n}+\mathrm{H}_{2} \mathrm{n} \quad \text { (catalyzed) } \\
& \mathrm{NO}_{3}+5 \mathrm{HCOOH} \rightarrow \mathrm{NH}_{3}+4 \mathrm{CO}_{2} \mathrm{n}+\mathrm{COOH}+3 \mathrm{H}_{2} \mathrm{O} \\
& \mathrm{Me}^{3+}+3 \odot \longrightarrow \mathrm{Me} \text { (black residue) }
\end{aligned}
$$$$
\text { where } \mathrm{Me}=\mathrm{Pd}, \mathrm{Rh}, \mathrm{Ru}, \mathrm{Cu}, \mathrm{Ag}, \mathrm{Te}, \mathrm{Se} \text { and } \mathrm{Pb} \text {, for example }
$$

The reduction of manganese dioxide $\left(\mathrm{MnO}_{2}\right)$ during stage I has also been suggested:

$$
\mathrm{MnO}_{2}+\mathrm{HCOOH} \rightarrow \mathrm{MnO}+\mathrm{CO}_{2} \mathrm{n}+\mathrm{H}_{2} \mathrm{O}
$$

An equivalent set of reactions might be proposed for the altemate reductants selected for this investigation (refer to equations $2 a-d, 3 a-d$ and $4 a-d$ and reaction equation 2 which is driven by $p H$ reduction).

Stage II (lactic acid)

$$
\begin{aligned}
& 3 \mathrm{HNO}_{2} \rightarrow \mathrm{H}^{+}+\mathrm{NO}_{3}+2 \mathrm{NO} \mathrm{n}+\mathrm{H}_{2} \mathrm{O} \\
& 6 \mathrm{HNO}_{2}+\mathrm{CH}_{3} \mathrm{CHOHCO}_{2} \mathrm{H} \rightarrow 3 \mathrm{~N}_{2} \mathrm{On}+3 \mathrm{CO}_{2} \mathrm{n}+6 \mathrm{H}_{2} \mathrm{O} \\
& 12 \mathrm{HNO}_{2}+\mathrm{CH}_{3} \mathrm{CHOHCO}_{2} \mathrm{H} \rightarrow 12 \mathrm{NO}+3 \mathrm{CO}_{2} \mathrm{n}+9 \mathrm{H}_{2} \mathrm{O}
\end{aligned}
$$

Stage II (citric acid)

$$
\begin{aligned}
& 3 \mathrm{HNO}_{2} \longrightarrow \mathrm{H}^{+}+\mathrm{NO}_{3}+2 \mathrm{NO} n+\mathrm{H}_{2} \mathrm{O} \\
& 8 \mathrm{HNO}_{2}+\mathrm{HOC}\left(\mathrm{CH}_{2} \mathrm{CO}_{2}\right)_{2} \mathrm{CO}_{2} \mathrm{H} \longrightarrow 4 \mathrm{~N}_{2} \mathrm{On}+6 \mathrm{CO}_{2} \mathrm{n}+7 \mathrm{H}_{2} \mathrm{O} \\
& 16 \mathrm{HNO}_{2}+\mathrm{HOC}\left(\mathrm{CH}_{2} \mathrm{CO}_{2}\right)_{2} \mathrm{CO}_{2} \mathrm{H} \longrightarrow 16 \mathrm{NO}+6 \mathrm{CO}_{2} \mathrm{n}+11 \mathrm{H}_{2} \mathrm{O}
\end{aligned}
$$

Stage II (alvcolic acid)

$$
3 \mathrm{HNO}_{2} \longrightarrow \mathrm{H}^{+}+\mathrm{NO}_{3}+2 \mathrm{NO} \mathrm{N}+\mathrm{H}_{2} \mathrm{O}
$$




$$
\begin{aligned}
& 6 \mathrm{HNO}_{2}+2 \mathrm{HOCH}_{2} \mathrm{CO}_{2} \mathrm{H} \longrightarrow 3 \mathrm{~N}_{2} \mathrm{On}+4 \mathrm{CO}_{2} \mathrm{n}+7 \mathrm{H}_{2} \mathrm{O} \\
& 6 \mathrm{HNO}_{2}+\mathrm{HOCH}_{2} \mathrm{CO}_{2} \mathrm{H} \longrightarrow \mathrm{NO}+2 \mathrm{CO}_{2} \mathrm{n}+5 \mathrm{H}_{2} \mathrm{O}
\end{aligned}
$$

Stage $\pi$ (oxalic acid)

$$
\begin{aligned}
& 3 \mathrm{HNO}_{2} \longrightarrow \mathrm{H}^{+}+\mathrm{NO}_{3}+2 \mathrm{NO} \text { n } \\
& 2 \mathrm{HNO}_{2}+2 \mathrm{HO}_{2} \mathrm{CCO}_{2} \mathrm{H} \longrightarrow \mathrm{N}_{2} \mathrm{On}+4 \mathrm{CO}_{2} \mathrm{n}+3 \mathrm{H}_{2} \mathrm{O} \\
& 2 \mathrm{FNO}_{2}+\mathrm{HO}_{2} \mathrm{CCO}_{2} \mathrm{H} \longrightarrow 2 \mathrm{NO}+2 \mathrm{CO}_{2} \mathrm{n}+2 \mathrm{H}_{2} \mathrm{O}
\end{aligned}
$$

The stoichiometry of carbonic acid decomposition (Stage I) is expected to remain unchanged. However, the stoichiometry of stage II reactions suggests that differences in $\mathrm{CO}_{2}$ production might be observed for the various reductants, and as for $\mathrm{HCOOH}$, would depend on the favored reaction pathway.

As for stage III, decomposition reactions might occur via catalysis or due to thermal sensitivities such as the catalysed decomposition of $\mathrm{HCOOH}$ shown in equation (5). The $\mathrm{NH}_{3}$

$$
\mathrm{HCOOH} \longrightarrow \mathrm{CO}_{2} \mathrm{n}+\mathrm{H}_{2} \mathrm{n}
$$

producing reaction (6) is also a catalysed reaction which might have a conterpart amoung the

$$
\mathrm{NO}_{3}+5 \mathrm{HCOOH} \longrightarrow \mathrm{NH}_{3}+4 \mathrm{CO}_{2} \mathrm{n}+\mathrm{COOH}+3 \mathrm{H}_{2} \mathrm{O}
$$

altemate reductant candidates. By using each alternate reductant under similar waste slumry processing conditions which result in the generation of $\mathrm{H}_{2}$ and $\mathrm{NH}_{3}$ when $\mathrm{HCOOH}$ is used, any tendency for comparable reaction pathways to occur should be observed as $\mathrm{H}_{2}$ and/or $\mathrm{NH}_{3}$ in the offgas or condensate

\subsection{CONCLUUSTONS AND RECOMMENDATTONS}

Very low to nondetectable generation rates of $\mathrm{NH}_{3}$ and $\mathrm{H}_{2}$ have been observed when processing simulated (non-radioactive), pre-treated neutralized current acid waste (NCAW) with the organic acids, citric, glycolic, lactic, oxalic and with nitric acid. Further evaluation demonstated that Glycolic and nitric acids could be used to make melter feeds with both acceptable theological properties and total oxide loading while melter feed made using oxalic acid treated waste slurry does not meet both criteria. Two HTM melter feeds, one made with waste slurry simulant treated with olycolic acid and the other made with nitric acid treated slurry are recommended for evaluation as melter feeds in the SSHTM.

\section{OOBJECTIVES}

The overall objective of the laboratory-scale feed preparation chemistry tests is to provide data needed for plant design, safety, permitting, and operations. The primary objectives of the laboratory testing were to study the effects of modifying the baseline flowsheet on the offgas composition, generation rate and total volume, to use the flowsheet selection criteria to narrow the number of altemative flowsheets, and further recommend these down selected flowsheets for testing through the melter feed processing stage to determine if the melter feed composition, physical 
properties, and melter processing steps met all af the flowsheet selection criteria. The melter feed would be processed to meet the N508 glass composition specifications. This information would ultimately be used to select two altemate melter feed preparation process flowsheets for HTM testing. A fundamental understanding of the chemical reactions is necessary to adapt the feed preparation process to a variety of feed compositions and to predict outcomes under both routine and upset processing conditions.

The specific objectives of the FY 1993 and FY 1994 Tests were to down select the number of potential candidate flowsheets from six to two which would be further evaluated by using for pilot seale runs (SSHTM). The down selection process is diagrammed in Figure 3.1. Baseline data is first established for the standard $\mathrm{HCOOH}$ processing. The candidates were first compared to the base line data for $\mathrm{H}_{2}$ and $\mathrm{NH}_{3}$ production and then on theological properties and total redox capacity. A brief description and specific objective is given in Table 3.2 for each of the 11 tests conducted. 


\title{
Table 3.1 - Alternate Flowsheet Selection Procedure
}

\author{
Establish Basellne \\ - Three Formic Acld baseline llowsheels were used to establish benchmark levels of hydrogen and \\ ammonia production \\ Select Candldates \\ Nonreducing Flowsheet. \\ - Nitric Acid \\ - Untreated Wasto Slurry \\ Beducina Flowsheels \\ - Citric Acid \\ - Glycolic Acid \\ - Lactic Acld \\ - Oxalle Acld \\ Evaluate Candidates - \\ Gas Production \\ Evaluate Candidates - \\ Rheology \\ Choose Two Finalists \\ - Choose the candidate capable of providing the \\ best waste loading and iheological propertios. \\ - Demonstrates acceptable reductlons of $\mathrm{H2}$ and \\ $\mathrm{NH} 3$ compared to baseline and high waste \\ loading. Choose the successtul candidate with \\ the lowest reducing polential. \\ - Evaluate each Waste Slurry Processing flowsheet on the basis of hydrogen and ammonla production \\ compared to the Formic Acid baselino. \\ - Evaluate selected melter feed slurry processing flowsheots on the basis of mainty theological \\ properties and waste loading crileria.
}


Table 3.2 Test Descriptions and Objectives.

Test Identification

T94-HCOOH-BASE-1

T94-HCOOH-BASE-2

T94-HCOOH-BASE-3

T94-LACTIC-1

T94-CITRIC-1

T94-GLYCOLIC-1

T94-FPGLYC-1

T94-HNO3-1

T94-FPHNO3-1

T94-OXALIC-1

T94-FPOXAL-1
Descriotion

Process w/formic acid

Process w/lactic acid

Process w/citric acid

Process w/glycolic acid

Process w/glycolic acid

Process w/nitric acid

Process w/nitric acid

Process w/oxalic acid

Process w/oxalic acid
- Objectives

Base case for reference processing conditions; establish reproducibility of laboratory tests.

Examine $\mathrm{H}_{2}$ and $\mathrm{NH}_{3}$ generation.

Examine $\mathrm{H}_{2}$ and $\mathrm{NH}_{3}$ generation.

Examine $\mathrm{H}_{2}$ and $\mathrm{NH}_{3}$. generation.

Produce simulated melter feed using minimum amount of organic acid for suitable feed rheology. Examine $\mathrm{H}_{2}$ and $\mathrm{NH}_{3}$ generation.

Rheology characteristics; examine $\mathrm{H}_{2}$ and $\mathrm{NH}_{3}$ generation.

Produce simulated melter feed using minimum amount of acid for suitable feed theology. Rheology characteristics; examine $\mathrm{H}_{2}$ and $\mathrm{NH}_{3}$ generation.

Examine $\mathrm{H}_{2}$ and $\mathrm{NH}_{3}$ generation.

Produce simulated melter feed using minimum amount of organic acid for suitable feed rheology. Examine $\mathrm{H}_{2}$ and $\mathrm{NH}_{3}$ generation. 


\section{O APPROACH}

The approach taken to perform the testing is described below. The HWVP feed simulants and formulations are described along with test methods and equipment. Comparisons of test conditions for FY 1994 tests and tests completed in FY $1991-93$ are indicated where significant differences exist to provide a basis for comparisons of data.

\subsection{Description of Simulants}

One source of stock NCAW simulants was used for the FY 1993 and FY 1994 tests. The simulant, slurry integrated performance test (SIPT), was prepared on a laboratory scale using a largescale preparation procedure. The FY 1991 reference NCAW and simulant target compositions aregiven in Table 4.1. The flow diagram of the formulation procedures for the various simulants were given in an earlier report (Smith et al. 1995, see Appendix B of that report for general information and reference). Note that "noble metals" refers to $\mathrm{Pd}, \mathrm{Rh}$, and $\mathrm{Ru}$ in the amounts indicated in Table 4.1. 
Table 4.1. Reference and Simulant NCAW Feed Compositions

\begin{tabular}{|c|c|c|c|c|c|}
\hline \multicolumn{4}{|c|}{ FY 1991 Pretreated NCAW Feed Composition(o) } & \multicolumn{2}{|c|}{ NCAW Simulant Composition(b) } \\
\hline $\begin{array}{c}\text { Oxide } \\
(0) \\
\end{array}$ & $\begin{array}{c}\text { Foed Oxides } \\
\text { wr\% }\end{array}$ & $\begin{array}{c}\text { Moles } \\
\text { Element/L Feed } \\
(125 \mathrm{gWO} / \mathrm{L}) \\
\end{array}$ & $\begin{array}{c}\text { Substituted } \\
\text { Delete* }\end{array}$ & $\begin{array}{c}\text { Feed Oxides } \\
\text { wt\% }\end{array}$ & $\begin{array}{c}\text { Moles } \\
\text { ElementL Feed } \\
(125 \mathrm{~g} W O / L) \\
\end{array}$ \\
\hline $\mathrm{AB}_{2} \mathrm{O}$ & $1.20 \mathrm{E}-01$ & 1.29E-03 & -* & $1.22 \mathrm{E}-01$ & $1.32 E-03$ \\
\hline $\mathrm{Al}_{2} \mathrm{O}_{3}$ & $9.04 \mathrm{E}+00^{\circ}$ & $2.22 \mathrm{E}-01$ & - & $9.25-E+\infty 0$ & 2.27E-01 \\
\hline $\mathrm{Am}_{2} \mathrm{O}_{3}$ & 7.22E-02 & 5.38E-07 & Del(d) & - & - \\
\hline $\mathrm{As}_{2} \mathrm{O}_{3}$ & 4.25E-05 & 3.41E-04 & $\operatorname{Dej}(())$ & - & - \\
\hline $\mathrm{B}_{2} \mathrm{O}_{3}$ & 5.75E-03 & 2.06E-04 & - & $5.86 \mathrm{E}-03$ & 2.10E.04 \\
\hline $\begin{array}{l}B \times O \\
B \infty O\end{array}$ & $\begin{array}{l}1.76 E-01 \\
1.01 E-01\end{array}$ & $\begin{array}{l}1.43 E-03 \\
5.04 E-03\end{array}$ & Sub $M_{g}{ }^{(e)}$ & $\begin{array}{c}1.79 E-01 \\
-\end{array}$ & $\begin{array}{r}1.46 \mathrm{E}-03 \\
-\end{array}$ \\
\hline Br & $\infty$ & & $N A()^{\circ}$ & - & - \\
\hline CaO & 7.91E-01 & 1.76E-02 & - & 8.06E-01 & 1.80E-02 \\
\hline $\begin{array}{l}\mathrm{CdO} \\
\mathrm{CeO}_{2}\end{array}$ & $\begin{array}{l}3.02 E+00 \\
6.05 E-01\end{array}$ & $\begin{array}{l}2.94 E-02 \\
4.39 E-03\end{array}$ & $\overline{-}$ & $\begin{array}{l}3.08 E+00 \\
6.56 E-01\end{array}$ & $\begin{array}{l}3.00 \mathrm{E}-02 \\
4.77 \mathrm{E}-03\end{array}$ \\
\hline $\mathrm{Co}_{2} \mathrm{O}_{3}$ & - & - & to be determined(n) & - & - \\
\hline $\mathrm{Cr}_{2} \mathrm{O}_{3}$ & 2.62E-01 & $4.30 \mathrm{E}-03$ & - & 2.67E-01 & 4.39E-03 \\
\hline $\mathrm{Cs}_{2} \mathrm{O}$ & 6.05E-01 & 5.32E-03 & - & 6.12E-01 & 5.43E-03 \\
\hline $\begin{array}{l}\mathrm{Cu} \mathrm{O} \\
\mathrm{Dy}_{2} \mathrm{O}_{3}\end{array}$ & $\begin{array}{l}2.45 \mathrm{E}-01 \\
1.04 \mathrm{E}-04\end{array}$ & $\begin{array}{l}3.85 E-03 \\
6.98 E-07\end{array}$ & Sub Nd(b)* & $\begin{array}{c}2.50 \mathrm{E}-01 \\
-\end{array}$ & $\begin{array}{r}3.93 E-03 \\
-\end{array}$ \\
\hline $\mathrm{E}_{2} \mathrm{O}_{3}$ & $3.08 \mathrm{E}-06$ & 2.02E-08 & Sub NdG* & - & - \\
\hline $\mathrm{Eu}_{2} \mathrm{O}_{3}$ & $2.02 E-02$ & $1.42 \mathrm{E}-0.4$ & Sub Nd(w) & - & - \\
\hline $\begin{array}{l}\mathrm{F} \\
\mathrm{Fe}_{2} \mathrm{O}_{3}\end{array}$ & $\begin{array}{l}9.70 E-02 \\
2.82 E+01\end{array}$ & $\begin{array}{l}\text { 6.38E-03 } \\
4.42 E-01\end{array}$ & - & $\begin{array}{l}9.90 E-02 \\
2.88 E+01\end{array}$ & $\begin{array}{l}6.52 E-03 \\
4.51 E-01\end{array}$ \\
\hline $\mathrm{G}_{2} \mathrm{O}_{3}$ & $3.70 E-03$ & 2.57E-05 & Sub $N a(b) *$ & - & - \\
\hline $\mathrm{GeO}_{2}$ & 1.57E-04 & 1.82E-06 & Add* & $1.56 \mathrm{E}-04$ & $1.86 E-06$ \\
\hline $\begin{array}{l}\mathrm{H}_{8} \mathrm{O} \\
\mathrm{HO}_{2} \mathrm{O}_{3}\end{array}$ & $5.32 \overrightarrow{E-06}$ & $3.52 \mathrm{E}-\overrightarrow{08}$ & $\begin{array}{l}\text { NAA' } \\
\text { Sub Nd(e)* }\end{array}$ & $=$ & $=$ \\
\hline I & 4.50E-06 & 4.36E-08 & $-(b)$ & $4.60 \mathrm{E}-06$ & 4.53E-08 \\
\hline $\mathrm{In}_{2} \mathrm{O}_{3}$ & - & - & N/A & - & - \\
\hline $\mathrm{K}_{2} \mathrm{O}$ & $1.96 \mathrm{E}-01$ & 5.21E-03 & - & $2.00 \mathrm{E} \cdot 01$ & $5.32 \mathrm{E}-03$ \\
\hline $\mathrm{La}_{2} \mathrm{O}_{3}$ & $6.53 \mathrm{E}-01$ & 5.01E-03 & - & 6.67E-01 & $5.12 \mathrm{E} \cdot 03$ \\
\hline $\mathrm{Li}_{2} \mathrm{O}$ & $1.84 \mathrm{E}-04$ & 5.92E-06 & - & $7.23 \mathrm{E}-05$ & $6.05 E \cdot 06$ \\
\hline $\mathrm{MgO}$ & $2.02 \mathrm{E}-01$ & $6.25 \mathrm{E} .03$ & - & 3.72E- 01 & 1.15E-02 \\
\hline $\mathrm{MnO}_{2}$ & $2.14 E+00$ & $3.08 E-02$ & - & $2.19 E+00$ & 3.15E-02 \\
\hline $\mathrm{MoO}_{3}$ & 5.59E-01 & 4.85E-03 & - & 5.70E-01 & $4.95 E-03$ \\
\hline $\mathrm{Na}_{2} \mathrm{O}$ & $2.14 E+01$ & $8.64 E-01$ & - & $2.19 \mathrm{E}+01$ & $8.82 \mathrm{E}-01$ \\
\hline $\mathrm{Nb}_{2} \mathrm{O}_{3}$ & $1.01 \mathrm{E}-02$ & $1.08 \mathrm{E}-04$ & - & $1.03 E-02$ & $1.10 \mathrm{E}-04$ \\
\hline $\mathrm{Nd}_{2} \mathrm{O}_{3}$ & 5.78E.01 & $4.29 \mathrm{E}-03$ & - & $3.56 E+00$ & 2.64E-02 \\
\hline NiO & $2.30 \mathrm{E}+00$ & $3.85 \mathrm{E}-02$ & - & $2.35 E+\infty 0$ & $3.93 E-02$ \\
\hline $\mathrm{NpO}_{2}$ & - & . & NAA(n) & - & - \\
\hline $\mathrm{P}_{2} \mathrm{O}_{5}$ & 8.72E-01 & $1.53 \mathrm{E}-02$ & - & 8.87E-01 & $1.56 E-02$ \\
\hline $\mathrm{PbO}_{2}$ & 7.00E-01 & $3.66 \mathrm{E}-03$ & - & 7.15E-01 & $3.74 E-03$ \\
\hline$P O^{-}$ & $1.20 \mathrm{E}-01$ & 1.23E-03 & $\ldots$ & $1.23 \mathrm{E}-01$ & $1.26 \mathrm{E}-03$ \\
\hline $\mathrm{Pm}_{2} \mathrm{O}_{3}$ & $4.60 \mathrm{E}-02$ & 3.32E-04 & SubNd & - & - \\
\hline $\mathrm{P}_{2} \mathrm{O}_{3}$ & $1.53 E-01$ & $1.16 \mathrm{E}-03$ & $\infty$ & $1.56 \mathrm{E}-01$ & $1.18 \mathrm{E}-03$ \\
\hline $\mathrm{PuO}_{2}$ & $6.00 \mathrm{E}-02$ & 2.77E-04 & Sub Ce & - & - \\
\hline $\mathrm{Rb}_{2} \mathrm{O}_{3}$ & 5.75E-02 & $6.56 \mathrm{E}-04$ & - & 5.87E-02 & $6.70 \mathrm{E}-04$ \\
\hline
\end{tabular}


FY 1991 Pretrented NCAW'Feed Composition(a)

\begin{tabular}{|c|c|c|c|c|c|c|}
\hline \multicolumn{4}{|c|}{ FX 1991 Pretrented NCAW· Feed Composition(s) } & \multicolumn{3}{|c|}{ NCAW Simulant Composition(b) } \\
\hline $\begin{array}{c}\text { Oxide } \\
\text { (O) }\end{array}$ & $\begin{array}{c}\text { Feed Oxides } \\
\text { wtys }\end{array}$ & $\begin{array}{c}\text { Moles } \\
\text { Element/L Feed } \\
(125 \text { gWO/L) }\end{array}$ & $\begin{array}{l}\text { Substitute/ } \\
\text { Delete* }\end{array}$ & $\begin{array}{c}\text { Feed Oxides } \\
\text { wt\% }\end{array}$ & $\begin{array}{c}\text { Moles } \\
\text { Element/L Fe } \\
(125 \mathrm{gWO} / \mathrm{L}\end{array}$ & Led \\
\hline $\mathrm{Rh}_{2} \mathrm{O}_{3}$ & $1.04 E-01$ & $1.02 E-03$ & - & $1.06 \mathrm{E}-01$ & 1.04E-03 & \\
\hline $\mathrm{Ru}_{2} \mathrm{O}_{3}$ & $3.80 \mathrm{E}-01$ & 3.77E-03 & - & 3.87E:01 & 3.85E-03 & \\
\hline $\mathrm{SO}_{3}$ & 6.55E-01 & $1.02 E-02$ & - & 6.69E.01 & $1.04 \mathrm{E}-02$ & \\
\hline $\mathrm{Sb}_{2} \mathrm{O}_{3}$ & 5.88E-03 & $5.00 \mathrm{E}-05$ & - & 5.95E-03 & S.11E-05 & \\
\hline $\mathrm{SeO}_{2}$ & $1.59 \mathrm{E}-02$ & $1.78 \mathrm{E}-04$ & - & $1.61 E-02$ & 1.82E-04 & \\
\hline $\mathrm{SiO}_{2}$ & $4.03 E+00$ & $8.38 \mathrm{E} .02$ & - & $4.11 E+00$ & 8.56E-02 & \\
\hline $\mathrm{Sm}_{2} \mathrm{O}_{3}$ & 7.50E-02 & $5.42 E-04$ & $-(d)$ & 7.72E-02 & 5.54E-04 & \\
\hline $\begin{array}{l}\mathrm{SnO} \\
\mathrm{SrO} \\
\mathrm{T}_{2} \mathrm{O}_{5}\end{array}$ & $\begin{array}{l}1.08 \mathrm{E}-02 \\
1.19 \mathrm{E}-01 \\
3.33 \mathrm{E}-03\end{array}$ & $\begin{array}{l}9.78 \mathrm{E}-05 \\
1.43 \mathrm{E}-03 \\
1.88 \mathrm{E}-05\end{array}$ & $\begin{array}{l}- \\
-\end{array}$ & $\begin{array}{l}1.08 E-02 \\
1.21 E-01 \\
3.39 E-03\end{array}$ & $\begin{array}{l}9.99 E-05 \\
1.46 E-03 \\
1.92 E-05\end{array}$ & \\
\hline $\mathrm{Tb}_{2} \mathrm{O}_{3}$ & 2.26E-04 & $1.54 \mathrm{E}-06$ & SubNd & - & - & - \\
\hline $\mathrm{Te}_{2} \mathrm{O}_{7}$ & $1.52 \mathrm{E}-01$ & $1.23 \mathrm{E}-03$ & - & - & - & \\
\hline $\mathrm{TCO}_{2}$ & $1.07 E-01$ & 7.77E-04 & - & $1.01 \mathrm{E}-01$ & $7.94 \mathrm{E}-04$ & \\
\hline $\mathrm{ThO}_{2}$ & - & - & SubZz & - & - & \\
\hline $\mathrm{TO}_{2}$ & $6.52 \mathrm{E}-01$ & $1.02 E-02$ & - & $6.66 E-01$ & $1.04 \mathrm{E}-02$ & \\
\hline $\mathrm{Tm}_{2} \mathrm{O}_{3}$ & $1.68 E-10$ & $1.09 \mathrm{E}-12$ & SubNd(0) & - & - & \\
\hline $\mathrm{U}_{3} \mathrm{O}_{8}$ & $4.74 E+00$ & 2.11E-02 & SubNd(d)* & - & - & \\
\hline $\mathrm{Y}_{2} \mathrm{O}_{3}$ & 7.99E-02 & 8.85E.04 & - & 8.17E-02 & $9.04 \mathrm{E}-04$ & \\
\hline $\begin{array}{l}\mathrm{ZnO} \\
\mathrm{ZO}_{2}\end{array}$ & $\begin{array}{l}3.34 E-01 \\
1.51 E+01\end{array}$ & $\begin{array}{l}5.13 E-03 \\
1.53 E-01\end{array}$ & $-(d)$ & $\begin{array}{l}3.41 E-01 \\
1.54 E+01\end{array}$ & $\begin{array}{l}5.24 E-03 \\
1.56 E-01\end{array}$ & \\
\hline Sum & $1.00 \mathrm{E}+02$ & $2.02 E+00$ & $-(d)$ & $1.00 E+02$ & $2.06 E+00$ & \\
\hline & $\begin{array}{l}1991 \text { Pretreated } \\
\text { Composit }\end{array}$ & $\begin{array}{l}\text { TCAW Feed } \\
\text { on }\end{array}$ & NCAW Simulant & & & \\
\hline $\begin{array}{l}\text { An- } \\
\text { ions }\end{array}$ & $\begin{array}{l}8 / 100 \mathrm{~g} \\
\text { Total Oxides }\end{array}$ & $\begin{array}{c}\text { gmoles } \\
\text { element/L }\end{array}$ & $\begin{array}{c}\text { moles } \\
\text { anion } / \mathrm{L}\end{array}$ & & & \\
\hline $\mathrm{NO}_{3}$ & $5.76 E+00$ & $1.16 \mathrm{E}-01$ & $1.16 \mathrm{E}-01$ & & & \\
\hline $\mathrm{NO}_{2}$ & $1.60 E+01$ & 4.35E-01 & 4.35E-01 & & & \\
\hline Cl- & $3.00 E-01$ & $1.06 \mathrm{E}-02$ & $1.06 \mathrm{E}-02$ & & & \\
\hline $\begin{array}{l}\mathrm{OH}_{\mathrm{SO}_{4}^{-2}}\end{array}$ & 7065 & O & 10 & & & \\
\hline $\mathrm{PO}_{4}^{-3}$ & $\begin{array}{l}7.80 \mathrm{E}-01 \\
7.84 \mathrm{E}-02\end{array}$ & $\begin{array}{l}1.02 \mathrm{E}-02 \\
1.03 \mathrm{E}-03\end{array}$ & $\begin{array}{r}1.03 E-02 \\
-\end{array}$ & & & \\
\hline $\mathrm{CO}_{3}^{-2}$ & $6.00 E+00$ & $1.25 E-01$ & $1.25 \mathrm{E}-01$ & & & \\
\hline Foc & $\begin{array}{l}9.70 \mathrm{E}-02 \\
1.34 \mathrm{E}-01 \\
4.50 \mathrm{E}-06\end{array}$ & $\begin{array}{l}6.38 \mathrm{E}-03 \\
1.39 \mathrm{E}-02 \\
4.36 \mathrm{E}-08\end{array}$ & $\begin{array}{l}6.42 \mathrm{E}-03 \\
1.39 \mathrm{E}-02 \\
4.46 \mathrm{E}-08\end{array}$ & & & \\
\hline
\end{tabular}


FY 1991-Pretreated NCAW Feed Composition(1)

Oxide Feed Oxides ElementL Feed Substitute/

NCAW Simulant Composition(b)

Feed Oxides ElementL Foed wt\% (125 \&WO/L)

(a) NCAW target composition supplied by WHC for FY 91 testing per. Smith, R. A. 1991. Revision of Pretrented Neutralized Current Acid Waste Composition-for FY 1991 Pilot Testing-Esratn Correction. Letter to J. M. Creer. "i915051.

(b) Adjusted troget composition bused on (x).

(c) Target composition for FY 1992 Base Case "1. Equal to (b) except for increased Pd, Rh, and Ru concentrations to mutch actul FY 1991 base case simulant composition.

(d) Radionetive.

(e) Toxic.

(f) None in reference feed composition.

(B) Expensive.

(h) Addition of $0.25 \mathrm{gl} / \mathrm{L}$ of feed is necessary to meet the gas chromatograph's detection limit for the malysis of volatilized iodine.

- New addition to simulant.

Note: All substimtions are based on the addition of the equivalent amount of mole element/2. 
The SIPT stock simulant was prepared in the laboratory according to the pilot-scale procedurekl using the same batch materials that were used to eventually produce the pilot scale batch. Test simulants used for the 11 tests are provided in Table 4.2. The procedures and source materials used to make all of the simulants were the same. Earlier work indicated that SIPT slurry simulant and the NCAW Base Case \#1 (RSM) used in earlier tests behaved in a similar manner.

The SIPT feed was prepared as summarized below. A mixed hydroxide slurry containing the major waste oxide elements ( $\mathrm{Fe}, \mathrm{Ni}, \mathrm{Zr}_{2} \mathrm{Al}$, and $\mathrm{Mn}$ ) was prepared. A second slurry, prepared by precipitating cation species from soluble nitrates (possibly including those of the noble metals) with insoluble components (oxides, fluorides), was added to the mixed hydroxide slurry. Excess nitrate and sodium were removed by washing. A third slurry of solubles/slightly soluble salts (halides, hydroxides, nitrates, nitrites, suifates, borates, phosphates, oxides, and oxalate) was added to the resulting mixture. For the batching of the SIPT slurry simulant, the batch components were added to the main batch in smaller groups, but the product was expected to be similar. For large-scale preparation, toxic minor components such as $\mathrm{SeO}_{2}$ were added last. The mixture was analyzed for $\mathrm{Na}^{+}$and $\mathrm{NO}_{3}-$, which were added in various amounts with other elements, and appropriate additions of $\mathrm{NaNO}_{3}$ were made to bring these components to target levels.

A separate noble-metals slurry was prepared to adjust the noble-metals concentration. That slurry was prepared with a nitric acid solution of the three noble metals ( $\mathrm{Pd}, \mathrm{Rh}, \mathrm{Ru})$ nitrates at known concentrations and in the desired proportions. The nitrate solution was titrated with $10 \mathrm{~N}$ $\mathrm{NaOH}$ to $\mathrm{pH}$ 7.5. During the $\mathrm{NaOH}$ addition, a brown precipitate began to form before $\mathrm{pH} 6$ was attained. Once the $\mathrm{NaOH}$ addition was completed, the solution was boiled for 10 to 15 minutes to complete the precipitation of $\mathrm{Ru}$. The slurry was then washed with deionized water to remove nitrate and sodium. The wash water was allowed to separate as a supernate over a period of 12 to 24 h and was then decanted. Several wash/decant cycles were completed. Analyses of the decanted supernates gave noble metals concentrations around 20 to $30 \mathrm{ppm}$, indicating that the hydroxide slurry retained $99.7 \%$ of the noble metals (i.e., assume $30 \mathrm{ppm} \mathrm{Rh}$ in $500 \mathrm{~mL}$ of washes [15 mg] out of $5,560 \mathrm{mg}$ in the slurry, or $0.27 \%$ ).

Though the process of producing a noble metal hydroxide slurry was similar to precipitating the noble metals directly into the slurry feed, the relationship of the noble metals to the other metal hydroxide precipitates may not be the same. When the noble metals are coprecipitated with the other hydroxides during slurry production, mixing of the hydroxides will be more complete, which may alter catalytic activity. Any differences that exist between the two noble metal processes for addition to the slurry feed simulants will most likely affect reactions catalyzed by noble metals such as the production of $\mathrm{H}_{2}$. This may be important when considering the results between tests performed using different stock simulants. Note, however, that all the test simulants are targeted to the composition given in Table 4.1 for the nominal NCAW composition. Analytical uncertainties associated with elemental analysis of waste simulants were reported by Wiemers et al. 1993.

Nitrite $\left(\mathrm{NO}_{2}{ }^{-}\right)$and nitrate $\left(\mathrm{NO}_{3}{ }^{-}\right)$are the principle ritrogen-containing species in the waste siurry. Nitrite is decomposed by adding reductants (in these tests, acids) to form $\mathrm{NO}_{x}, \mathrm{~N}_{2} \mathrm{O}$, and some $\mathrm{NO}_{3}$ - in the offgas. Nitrate is reduced to $\mathrm{NH}_{3}$ when the noble metals are catalytically active (i.e., when the NO2- concentration is very low or zero). For the reference NCAW composition, the target level for $\mathrm{NO}_{2}{ }^{-}$is 0.435 moles $/ \mathrm{L}$ of slumy simulant at $125 \mathrm{gWO} / \mathrm{L}$. The target level for $\mathrm{NO}_{3}{ }^{-}$is

11 "Procedure for the Preparation of Simulated HWVP NCAW Feed," TP92-SIPT-100, October 30, 1992.

12 "Test Instructions for Slurry-Integrated Performance Testing-Weight Out of Chemicals and Preparation of NCAW Simulant," TT92-SIPT-100, Rev. 0, October 15, 1992. 
0.116 moles $/ \mathrm{L}$ of slurry simulant at $125 \mathrm{gWO} / \mathrm{L}$. For the altemate reductant tests, the $\mathrm{NO}_{2} \cdot$ level was targeted at $1 / 3$ of the NCAW value, and the $\mathrm{NO}_{3} \cdot$ level at $300 \%$ of the NCAW value. This was done to accentiate conditions that could possibly increase $\mathrm{H}_{2}$ and $\mathrm{NH}_{3}$ generation based on indications from FY 1992 tests. Thus the experimental conditions were designed to somewhat accentuate generation of $\mathrm{H}_{2}$ and $\mathrm{NH}_{3}$ as a conservative approach to evaluating altemate reductants. The analytical values suggest that $\mathrm{NO}_{2} \cdot$ was on target and that $\mathrm{NO}_{3} \cdot$ ran a little high (not serious for the objectives of these tests). 
Table 4.2 Test Simulants Used for Testing in Fiscal Years 1993 and 1994.

Test Designation

T94-HCOOH-BASE-1

T94-HCOOH-BASE-2

T94-HCOOH-BASE-3

T94-LACTIC-1

T94-CITRIC-1

T94-GLYCOLIC-1

T94-FPGLYC-1

T94-HNO3-1

T94-FPHNO3-1

T94-OXALIC-1

T94-FPOXAL-1
Simulant2

FY 94 SIPT/NCAW slurry simulant with $30 \% \mathrm{NO}_{2} \cdot$ \& $300 \% \mathrm{NO}_{3}$.

FY 94 SIPT/NCAW slurry simulant with $30 \% \mathrm{NO}_{2}-$ \& $300 \% \mathrm{NO}_{3}$.

FY 94 SIPT/NCAW slurry simulant with $30 \% \mathrm{NO}_{2} \cdot$ \& $300 \% \mathrm{NO}_{3}$

FY 94 SIPT/NCAW siumy simulant with $30 \% \mathrm{NO}_{2} \cdot$ \& $300 \% \mathrm{NO}_{3}$

FY 94 SIPT/NCAW slumy simulant with $30 \% \mathrm{NO}_{3} \cdot$ \& $300 \% \mathrm{NO}_{3}$.

FY 94 SIPT/NCAW slurry simulant with $30 \% \mathrm{NO}_{2} \cdot \&$ $300 \% \mathrm{NO}_{3}$

FY 94 SIPT/NCAW slurry simulant

FY 94 SIPT/NCAW slurry simulant

FY 94 SIPT/NCAW slurry simulant

FY 94 SIPT/NCAW slurry simulant

FY 94 SIPT/NCAW slurry simulant

(a) The difference in the two simulants is based on observations that decreased nitrite and increased nitrate may increase $\mathrm{H}_{2}$ and $\mathrm{NH}_{3}$ generation respectively. The procedures and source materials used to make all of the simulants were the same.

\subsection{Test Methods and Equipment}

Test methods and equipment used during FY 1993-94 were essentially identical to those used during FY 1991 and FY 1992 (Wiemers et al. 1993; Smith et al. 1995), with the exception that offgas monitoring was done with a different offgas system for the FY 1993-94 tests. Figure 4.2.1 is a schematic of the instrumented reaction vessel. An overall schematic of the laboratory-scale feed preparation process system detailing the offgas system is given in Figure 4.2.2.

The test apparatus shown in Figure 4.2.1 consisted of a 2-L Pyrex@m kettle placed in a temperature-controlled heating mantle. The Pyrex@ kettle lid was modified to accept a

13 Pyrex is registered trademark of Coming Glass Works, Coming, New York. 


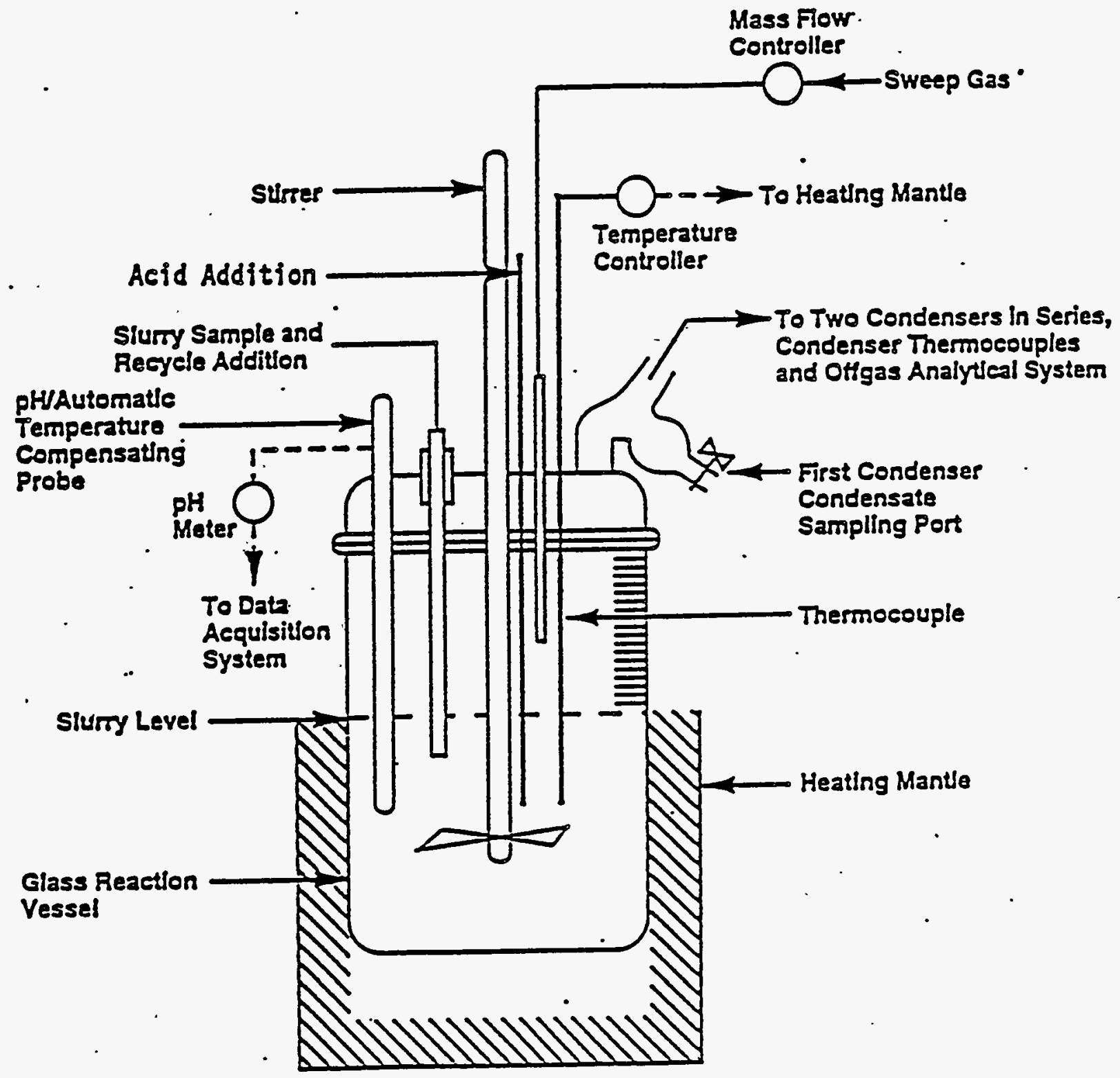

- Figure 4.2.1 - Schematic of the Laboratory-Scale Reaction Vessel Used for Waste Slurry Simulant Processing Tests and Melter Feed Preparation. 


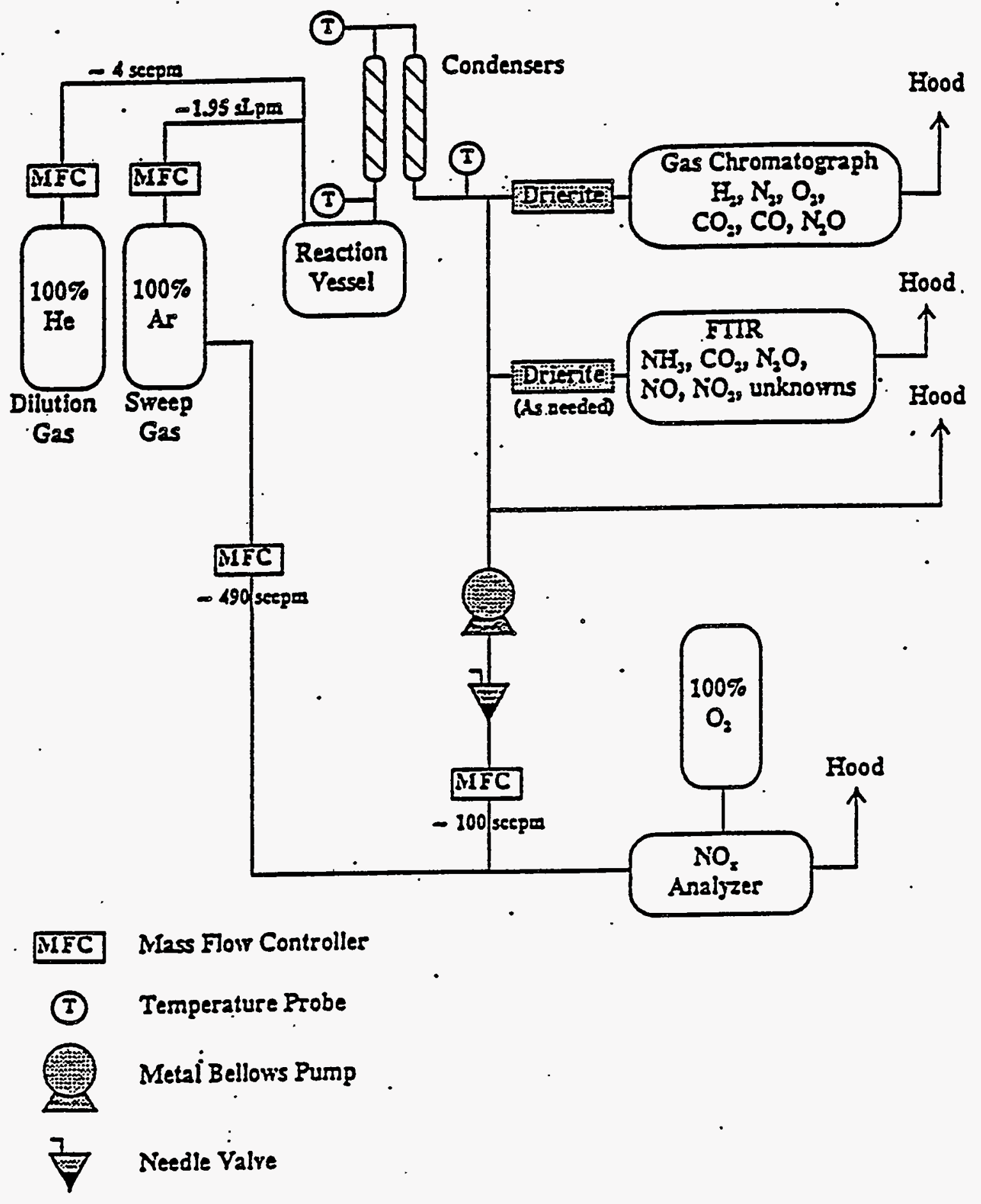

Figure 4.2.2 - Schematic of the Laboratory-Scale Offgas Equipment Configuration for Waste Slurry Simulant Processing Tests and Melter Feed Preparation. 
thermocouple, acid addition tube, $\mathrm{pH}$ electrode, $\mathrm{pH}$ automatic temperature compensator, agitator shaft, condenser, sweep gas inlet, slurry sampling/recycle waste stream simulant addition port, and baffle to enhance vertical mixing. A second condenser was added in series to the first condenser connected to the vessel lid. Acid was introduced below the surface of the simulant through a Teflon tube; a peristaltic pump controlled the addition rate. The argon (Ar) sweep gas carried offgases from the reaction vessel plenum through condensers at a rate of $\sim 1.95$ slpm. . Slumy pH was collected at $\sim 5$ min intervals on the data acquisition system and recorded manually when other observations were recorded. Slurry and gas temperatures were recorded manually.

Figure 4.2.2 is a schematic of the offgas equipment configuration. Real-time monitoring capabilities were used to characterize the changing generation rates of the major gaseous reaction products. The offigas was monitored using an MT14 M200 gas chromatograph for helium flow rate, $\mathrm{H}_{2}, \mathrm{CO}, \mathrm{N}_{2}, \mathrm{O}_{2}, \mathrm{CO}_{2}$, and $\mathrm{N}_{2} \mathrm{O}$, a Nicoletis 550 FTIR gas analyzer for $\mathrm{NH}_{3}, \mathrm{CO}_{2}, \mathrm{~N}_{2} \mathrm{O}, \mathrm{NO}, \mathrm{NO}_{2}$, and identification of unknown species, and chemiluminescent analyzers for $\mathrm{NO}$ and $\mathrm{NO}_{\mathrm{x}}$. Total exit gas flow rate was monitored by reference to calibrated inlet flow of helium with the argon purge gas. The nominal argon flow rate was $0.117 \mathrm{~m}^{3} / \mathrm{h}$ at standard temperature and pressure (STP). The slurry $\mathrm{pH}$ was continuously monitored during processing. The vessel was opened briefly to remove a sample for theology tésting but only during a period of low gas generation to minimize effects on offgas measurement.

The gas chromatograph produced data at a nominal gas sampling rate of -1 sample/ $2 \mathrm{~min}$, and the NONO ${ }_{x}$ analyzers at a rate of 1 sample/l min. The FIIR analyzer was set up to sample and produce data at 1 sample/5 min.

There was a difference in the time response of the gas chromatograph data and the $\mathrm{NO}_{\mathrm{x}}$ analyzer data because of differences in the amount of time to completely purge the systems of gas entering the analyzer lines. The net result was that gas chromatograph data ( $\mathrm{He}, \mathrm{CO}_{2}, \mathrm{~N}_{2} \mathrm{O}$ and $\mathrm{H}_{2}$ ) were delayed about 15 minutes compared to the NOx analyzer data. A simple way to correct this effect would be to shift the $\mathrm{GC}$ data 15 minutes toward earlier time to correlate $\mathrm{He}, \mathrm{CO}_{2}, \mathrm{~N}_{2} \mathrm{O}$ and $\mathrm{H}_{2}$ data with $\mathrm{NO}_{x}$ data. In general, this was not done because the exact shift was not determined until many of the test data sets had been analyzed. Since the offgas flow rate of $\mathrm{NO}_{x}$ is calculated by a method that utilizes ppm He measurements, a small systematic error was introduced by not time shifting the GC data before calculations were performed. Because total gas flow rate generally changed slowly with time and the total range was only about $10 \%$ of the nominal flow rate (generally maintained by Ar purge gas), the error. was not very large, probably less than 5\%. One test, Test T94-HCOOHBASE-3, was corrected for the time shift to evaluate the effect, and the $\mathrm{NO}_{x}$ profiles with and without the time-shift correction were indistinguishable when superimposed except for the time shift. Therefore, no further correction of other data was deemed necessary. It should be kept in mind that the major $\mathrm{NO}_{x}$ peak would coincide closely with a secondary $\mathrm{CO}_{2}$ peak in many of the offgas profiles if this time-shift correction were made. Moreover, the apparent time delay between initiation of acid addition and the start of $\mathrm{CO}_{2}$ offgas generation is an artifact of the time delay of the gas chromatograph.

Ammonia was monitored by analyses of slurry and condensate samples, and $\mathrm{NH}_{3}$ and $\mathrm{CO}_{2}$ were . monitored with the FTIR analyzer. Ammonia was expected to be trapped in the condensate until the condensate reached a fairly alkaline $\mathrm{pH}$. Soluble $\mathrm{NH}_{4}+$ was measured in the slumy and condensate

14 MTI Corporation, Fremont, California.

is Nicolet Corporation, Madison, Wisconsin 
samples by selective ion electrode (SIE). The FIIR was also used to monitor $\mathrm{CO}_{2}$ for a portion of Test T94-FPOxalic-1, and $\mathrm{CO}_{2}$ and $\mathrm{N}_{2} \mathrm{O}$ for Test T94-Oxalic-1.

Slurry and condensate samples were collected at the beginning and ending of specific stages or substages of the slurry processing. Typically, samples were taken at the initiation of processing and after acid addition and digestion. Condensate samples, by the way they are formed and collected, represent an average composition of the condensate for the previous processing period. Primary condensate was collected at the base of the first condenser at a rate of about $0.3 \mathrm{~mL} / \mathrm{min}$ during acid addition at $95^{\circ} \mathrm{C}$ and about $2 \mathrm{~mL} / \mathrm{min}$ during digestion at $101^{\circ}$ to $102^{\circ} \mathrm{C}$. Secondary condensate was collected at the base of the second condenser at a much slower rate, so that much smaller quantities were available for analysis.

Slurry and condensate samples were analyzed for $\mathrm{NO}_{2}^{\circ}, \mathrm{NO}_{3^{\circ}}$, and acid salt anions by ion chromatography (IC) and for $\mathrm{NH}_{4}+$ by selective ion electrode. Total slurry analysis was not carried out because all the test materials except for the SIPT simulant had been analyzed previously (Wiemers et al. 1993). The SIPT simulant prepared for the laboratory tests was fabricated using the same procedure and chemicals used to make up the pilot-scale batch. (Sodium was the only other component checked in this batch.) Nitrite, acid salt anions (species depending on which acid was added), and $\mathrm{CO}_{3}{ }^{2-}$ were the chief reactants consumed during slurry processing. An accurate measurement method for carbon was unavailable at the time of testing; therefore, carbonate analyses were not done.

The procedures common to the tests are outlined in the following sections. In some tests, deviations from these procedures may have been necessary to accomplish the purpose of the test, and these deviations are included in the information summarized in Appendix A.

\subsubsection{Preparations for Acid Addition}

1. Place a given weight of slurry simulant with known gram oxide waste loading and specific gravity into the precleaned reaction vessel.

2. Add preweighed shim chemicals $\left(\mathrm{NaNO}_{2}, \mathrm{NaNO}_{3}\right.$, and $\mathrm{Na}_{2} \mathrm{CO}_{3}$ ), if required.

3. Clamp the reaction vessel lid, modified for the instrumentation, agitation, sampling, and offgas collection, in place.

4. Heat the slurry to boiling, with vigorous agitation, for a period of 10 minutes to an hour and cool to the temperature at which acid is added. Air is used as the sweep gas during this stage.

\subsubsection{Acid Addition}

1. Establish the sweep gas $(99.99 \%$ Ar) flow rate.

2. Add acid at predetermined rate until addition complete.

3. Maintain temperature within $\pm 1^{\circ} \mathrm{C}$ (except under upset conditions).

4. Measure temperature, $\mathrm{pH}$, and offgas generation rate as a function of process time.

5. Collect condensate or reflux depending on $\mathrm{gWO} / \mathrm{L}$ objective. 


\section{2 .3 Hold Period at the Acid Addition Temperature (if required)}

1. Maintain the slurry temperature.

2. Continue all measurements.

3. Collect condensate or reflux depending on gWO/L objective.

\subsubsection{Digestion Peried (4 h)}

1. Raise the slurry temperature to boiling.

2. Continue all measurements.

3. Collect condensate or reflux depending on gWO/L objective.

During the tests, both condensate and slurry samples were taken. Primary condensate was collected from the first condenser while secondary condensate was collected from the second condenser. There was always 100 to 1000 times more primary condensate volume than secondary. A particular condensate sample was collected over a period of time and thus was a summation of condensed volatiles for a test period of significant duration. Slurry samples, on the other hand, were collected at specific times, generally before and after acid addition and after digestion. Other slurry samples were taken at different points in processing, depending on the test objectives. Slurry samples destined for chemical analysis were refrigerated.

A technical data log was maintained during the test. The primary function of the log was to record observations of slurry color and slurry behavior. The log was also used to record slurry temperature and $\mathrm{pH}$ as a backup record to the data acquisition system and to record the beginning and ending of the various test stages. Slurry observations included the degree of foaming, the actions taken to control foaming, the appearance of secondary phases in the form of films or scums on the slurry surface, and slurry color, which, for slurries in previous work (Smith et al. 1995), changed from an initial chocolate red-brown to a brown or dark gray-brown when the slumy was extensively formated.

Following the test, the remaining treated simulant was placed in a tightly capped, labeled container. This material was held in reserve for future melting; theology, or chemical studies.

The FY 1993-94 tests continued to use the modified feed preparation process procedures as initiated and practiced in FY 1992, with regard to the composition and flow rate of the sweep gas, boiling conditions, and refluxing during acid addition. Ar $-4.4 \% \mathrm{O}_{2}$ sweep gas was used during $\mathrm{FY}$ 1991, and Argon sweep gas plus 4.4\% $\mathrm{CH}_{4}$ was used during FY 1992 and 1993. The change to pure Ar plus a helium tracer (FY 1994) was made so that offgas reactions involving $\mathrm{O}_{2}$, such as the oxidation of $\mathrm{NO}$ to $\mathrm{NO}_{2}$, would not occur and the true slurry reaction products could be measured without interference. In FY 1991, condensate was refluxed during HCOOH addition, but in FY 1992 and later, the condensate was collected and analyzed. In FY 1992 and later, the slurry was boiled before adding $\mathrm{HCOOH}$ (and other acids for FY 1994) to purge the slurry of dissolved gases and during digestion to accelerate reactions and to more completely remove reaction gases. Rapid boiling was believed to be more prototypic of plant operating conditions. These differences should be kept in mind when comparing FY 1991, FY 1992, FY 1993 and FY 1994 results. 


\subsubsection{Melter Feed Preparation}

The following outline covers the major stages of waste slurry simulant processing to make melter feed. The details resulting from implementing these steps are recorded in the "Laboratory Melter Feed Preparation Activity Log" included in this section. An accounting sheet for the gram waste oxide is also provided.

\section{Laboratory Elowsheet}

Step 1: Obtain pre-concentrated slurry simulant from the small-scale slurry processing tank prior to processing $(-179 \mathrm{gWO} / \mathrm{L})$. Place $1.5 \mathrm{~L}$ of that slurry in reaction vessel. Set stirrer at 6 or higher and establish argon sweep gas flow.

- Take slumy and condensate samples.

Step 2: Heat sluiry to $93^{\circ} \mathrm{C}$. Titrate with nitric acid to a pH of $4.8 \pm 0.1$. Add $70 \mathrm{wt} \%$ acid solution: Period \#1 - $1.04 \mathrm{~g} / \mathrm{min}$. for 14 minutes; Period \#2 - $1.53 \mathrm{~g} / \mathrm{min}$. for 10 minutes; Period \#3 - $1.94 \mathrm{~g} / \mathrm{min}$. for the remainder of the test. (Incremental rates duplicate the small-scale processing run more precisely.)

- Take slurry and condensate samples.

Step 3: Concentrate slurry to $240 \mathrm{gWO} / \mathrm{L}$ by boiling during digestion period of 8 hours. (The longer digestion/concentration period more accurately duplicates the small-scale processing run.)

- Take slurry and condensate samples.

Step 4: $\quad$ Add $\mathrm{NaNO}_{3}$ and $\mathrm{SiO}_{2}$ to complete melter feed preparation. (12 $\mathrm{g} \mathrm{Na}_{2} \mathrm{O}$ per $100 \mathrm{gWO}$ as $32.0 \mathrm{~g} \mathrm{NaNO}_{3}$ per $100 \mathrm{gWO}, 88 \mathrm{~g} \mathrm{SiO}_{2}$ as sand (F-110) per $100 \mathrm{gWO}$ ). Final target HTM feed concentration is $433 \mathrm{gTO} / \mathrm{L}$.

- Take meiter feed samples.

Step 5: $\quad$ Melter feed theology evaluated. 


\section{ORESUITS AND DISCUSSION}

Three HCOOH reductant tests were completed to establish the reproducibility of laboratory-scale tests and to provide a baseline for evaluation of the alternate reductant tests. Alternate reductants, (lactic, citric, glycolic and oxalic acids) were compared to the reference HCOOH reductant in eight tests. Tests using $\mathrm{HNO}_{3}$ in place of $\mathrm{HCOOH}$ are also reported. The complete offgas data and analytical data for these tests are tabulated and plotted in the appendix, with selected data presented in the following sections to support discussion and major conclusions.

\section{Baseline Formic Acid Elowsheet}

Three tests were completed to provide a baseline and examine reproducibility of test data for the reference flowsheet with formic acid addition, Tests HCOOH-BASE-1, HCOOH-BASE-2 and HCOOH-BASE-3. In addition to baseline slurry preparation, additional processing was explored after digestion to detemine effects of $\mathrm{NaNO}_{2}$ addition (Test HCOOH-BASE-2) and $\mathrm{HNO}_{3}$ addition (Test HCOOH-BASE-3). These effects will also be discussed separately in this section.

The individual offgas profiles are shown in Figures 5.1.1 through 5.1.3 and to provide a visual comparison of the time dependency and evolution rates from the three formic acid flowsheet replicate runs an overlay of the three offgas profiles is provided in Figure 5.1.4. The average amounts of each gas measured are given in Table 5.1.1. For an equivalent elapsed time period of 300 minutes (representing the approximate end of Stage III), the total offgas for $\mathrm{CO}_{2}, \mathrm{H}_{2}, \mathrm{~N}_{2} \mathrm{O}$ and $\mathrm{NO}_{x}$ varied at most $1.4 \%, 20 \%, 30 \%$, and $6.6 \%$ from the average, respectively (refer to ranges shown in Table 5. 1). The relative standard deviation (RSD) varied from $0.7 \%$ to $15 \%$.

The average peak gas generation rates, ranges, and relative standard deviations for the three replicate formic acid flowsheet tests are given in Table 5.1.2. Reproducibility was best for Stages I and II. The calculated values for RSD were $4.8 \%$ for $\mathrm{CO}_{2}$ (Stage I), $5.9 \%$ for $\mathrm{NO}_{x}$, and $11 \%$ for $\mathrm{N}_{2} \mathrm{O}$ (worse case given for each gas). The greatest variations were observed for $\mathrm{CO}_{2}$ and $\mathrm{H}_{2}$ during Stage III, $16 \%$ and $23 \%$ RSD, respectively.

Only two of the three tests were used to estimate experimental error in the $\mathrm{H}_{2}$ measurement due to an equipment malfunction during Test HCOOH-BASE-1 Known differences in the operation and process conditions between Tests HCOOH-BASE-2 and HCOOH-BASE-3 were an increase in the final $\mathrm{pH}$ of test HCOOH-BASE-3 ( $\mathrm{pH}$ 4.2) compared with Test HCOOH-BASE-2 (pH 3.3); a 5\% increase in the amount of condensate collected and oxide loading for test HCOOH-BASE-2 compared with test $\mathrm{HCOOH}-\mathrm{BASE}-3$; and a more rapid heating to the boil after acid addition for test HCOOH-BASE-2 compared with test HCOOH-BASE-3.

Heating rate after acid addition is believed to be the primary contributor to differences observed in the amount and peak generation rates for $\mathrm{H}_{2}$ and $\mathrm{CO}_{2}$ during stage III. The temperature was increased from 95 to $101^{\circ} \mathrm{C}$ in 10 minutes for test HCOOH-BASE-2 compared to 51 minutes elapsed time for heat up in test HCOOH-BASE-3. Wiemers et al. 1993; Smith et al. 1995, and Ritter et al. 1992 have shown the dependency of gas generation rate on temperature, especially above $75^{\circ} \mathrm{C}$. The potential for using a lower processing temperature to reduce the $\mathrm{H}_{2}$ generation rate was also discussed by Smith et al. (1995).

The total $\mathrm{NH}_{3}$ measured in the slurry and condensate for each of the three tests was 0.019 , 0.0032 , and 0.0041 moles $/ 130 \mathrm{gWO}$ for Tests HCOOH-BASE-1, HCOOH-BASE-2 and HCOOH-BASE-3, respectively. Note that additional steps taken with tests HCOOH-BASE-2 and $\mathrm{HCOOH}-\mathrm{BASE}-3$, are likely the reason for the higher $\mathrm{NH}_{3}$ levels which are composite values 
Offgas Generation HCOOH-Base 1

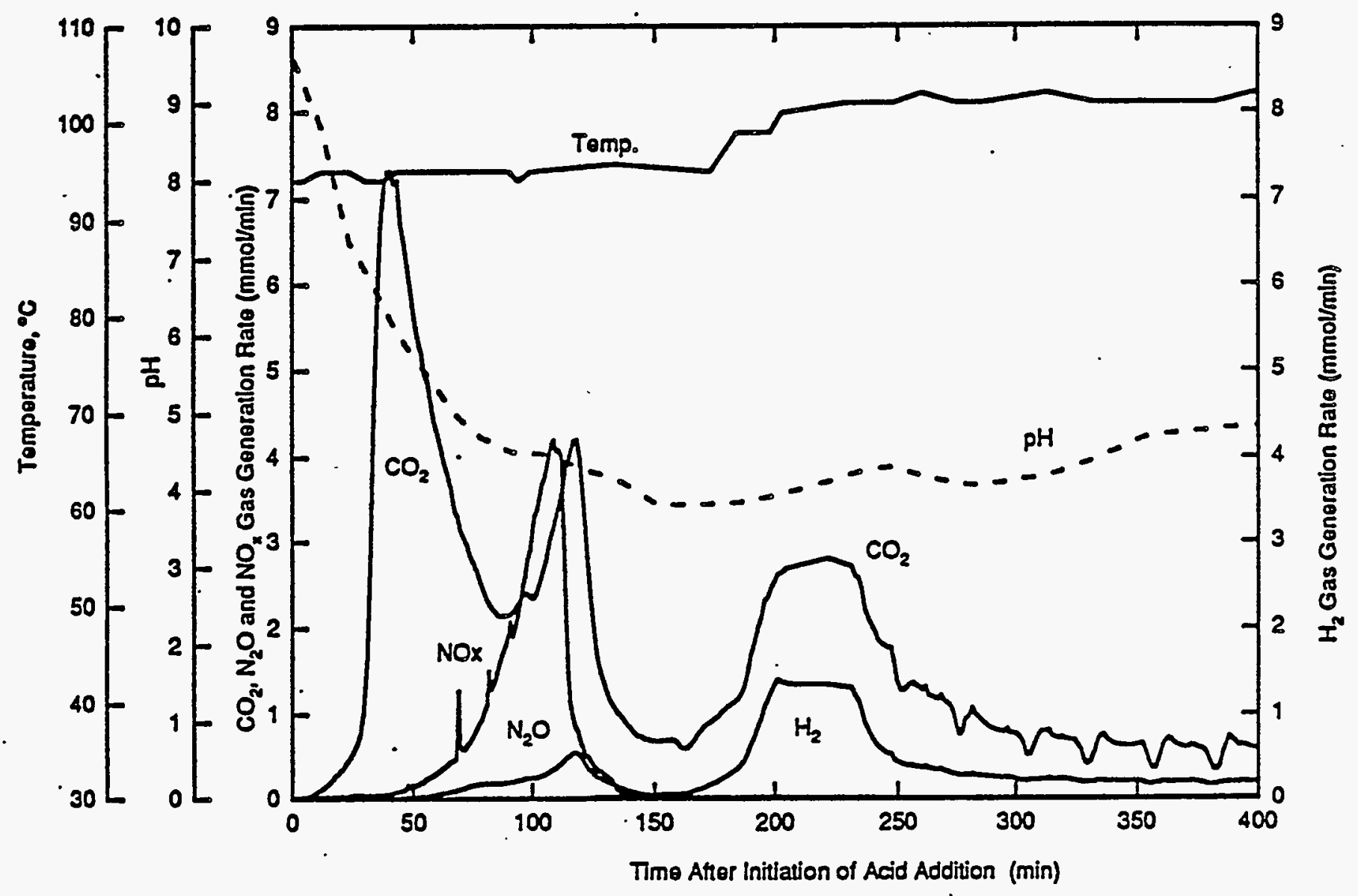

Figure 5.1.1 - Baseline Test T94-HCOOHBase-1 Offgas Profiles Covering a Period of 400 Minutes after the Initiation of $\mathrm{HCOOH}$ Addition. Temperature, $\mathrm{pH}, \mathrm{CO}_{2}, \mathrm{H}_{2}$, $\mathrm{NO}_{x_{0}}$ and $\mathrm{N}_{2} \mathrm{O}$ profiles are shown. 
Offgas Generation HCOOH Base 2

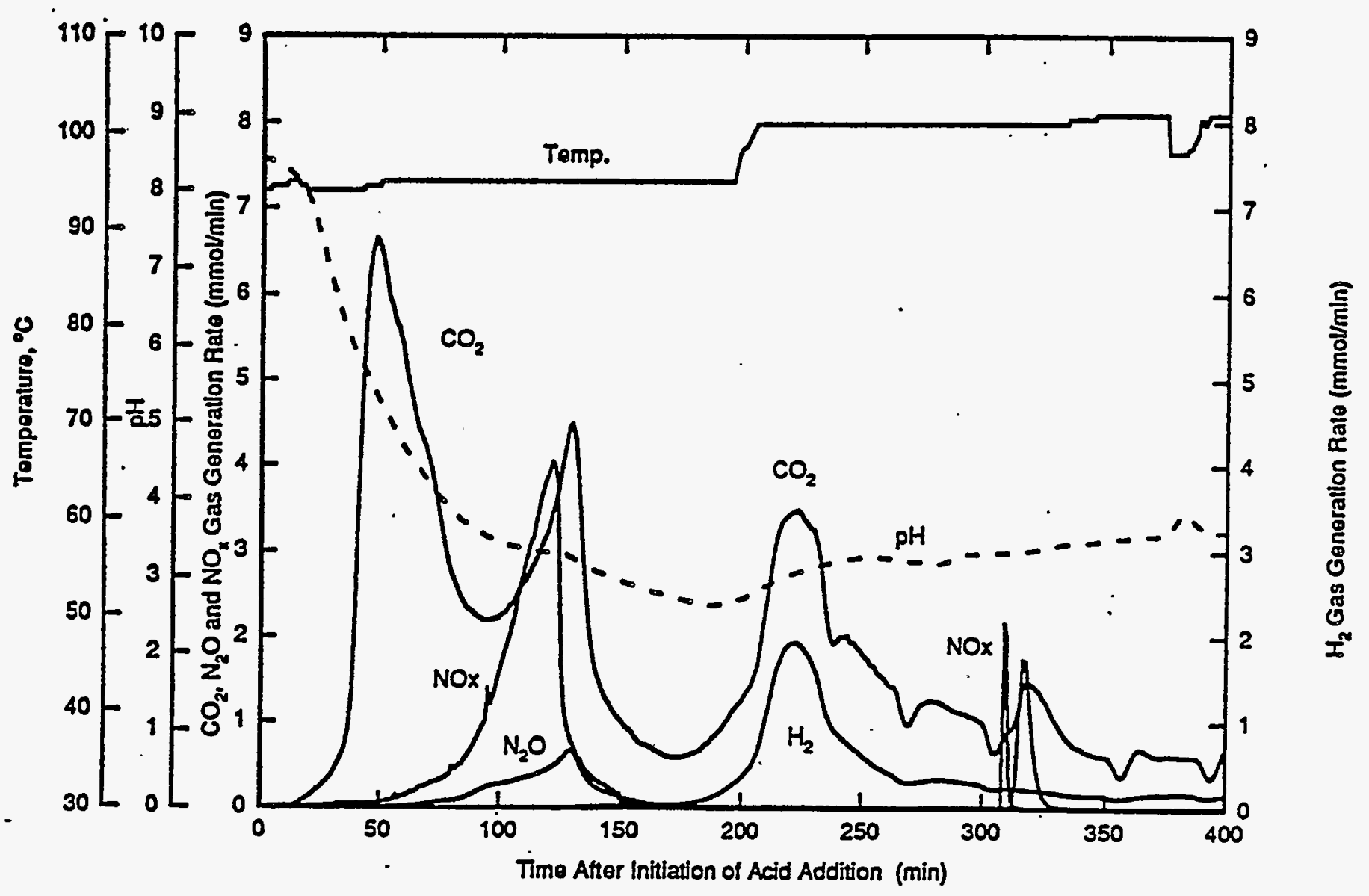

Figure 5.12 - Baseline Test T94-HCOOHBase-2 Offgas Profiles Covering a Period of 400 Minutes after the Initiation of $\mathrm{HCOOH}$ Addition. Temperature, $\mathrm{pH}, \mathrm{CO}_{2}, \mathrm{H}_{2}$, $\mathrm{NO}_{x}$, and $\mathrm{N}_{2} \mathrm{O}$ profiles are shown. 
Offgas Generation HCOOH-Base 3

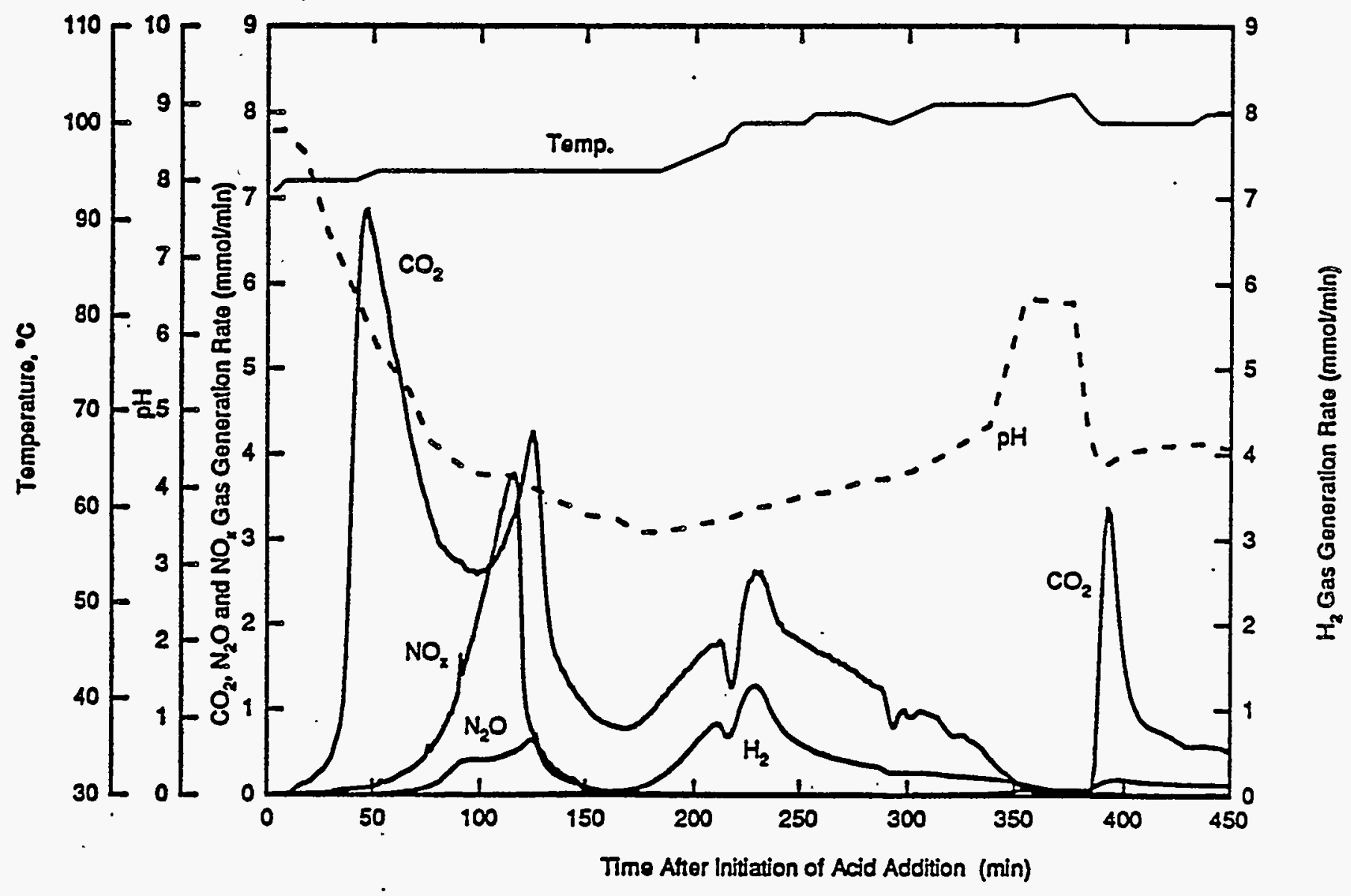

Figure 5.1.3 - Baseline Tests T94-HCOOHBase-3 Offgas Profiles Covering a Period of 450 Minutes after the Initiation of $\mathrm{HCOOH}$ Addition. Temperature, $\mathrm{pH}, \mathrm{CO}_{2}, \mathrm{H}_{2}$, $\mathrm{NO}_{x}$, and $\mathrm{N}_{2} \mathrm{O}$ profiles are shown. 
.Offgas Generation HCOOH Base 1,2 and 3

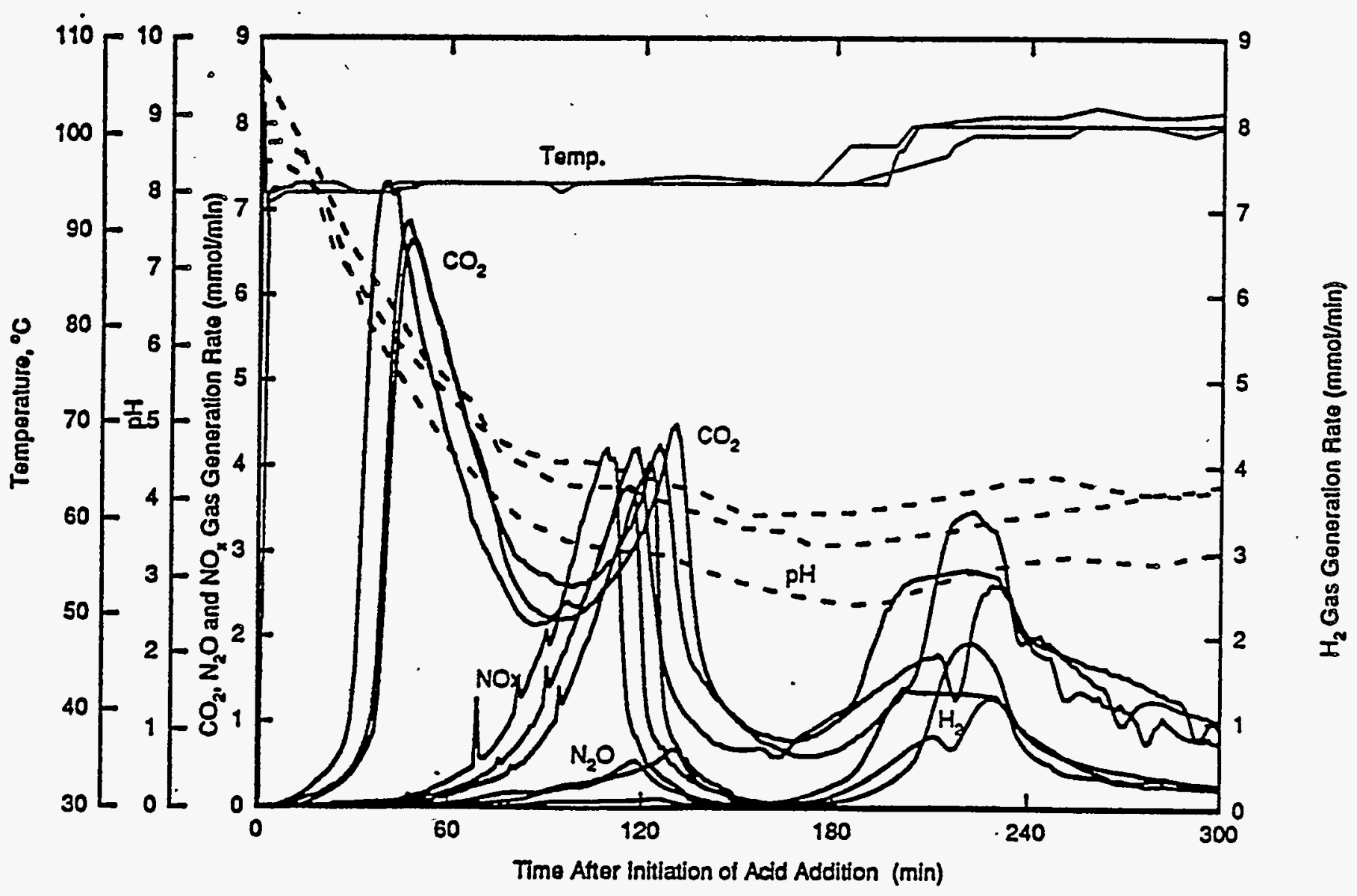

Figure 5.1.4 - Composit of the Three Baseline Test Offgas. Profiles Ilustrating the Observed Reproducibility over the First 300 Minutes after the Initiation of $\mathrm{HCOOH}$ Addition. Temperature, $\mathrm{pH}, \mathrm{CO}_{2}, \mathrm{H}_{2}, \mathrm{NO}_{x}$, and $\mathrm{N}_{2} \mathrm{O}$ profiles are shown. 
Table 5.1.1 - Offgas Generated per $130 \mathrm{gWO}$ / for the Baseline Tests

\begin{tabular}{|c|c|c|c|c|c|c|c|c|}
\hline & & & & \multicolumn{2}{|c|}{ Total H2 Generated } & & & \\
\hline & Total Test & Stage III & & \multicolumn{2}{|c|}{$(\mathrm{mM} / 130 \mathrm{gWO})$} & & & \\
\hline \multirow[t]{2}{*}{ Tost } & Time & Ending Thme & & & & & $\cdot$ & \\
\hline & $(m i n)$ & $(\min )$ & Slage I & Stage II & Stage III & Total & Initial vol & Init owOA \\
\hline T94.HCOOH-Base1 & 448.00 & 300.00 & 0.00 & 0.64 & 58.22 & 49.35 & 1.56 & 128.00 \\
\hline T94-HCOOH-Base2 & 465.00 & 300.00 & 0.00 & 0.81 & 54.50 & 73.65 & 1.55 & 128.00 \\
\hline \multirow[t]{6}{*}{ T94+HCOOH-Baso3 } & 347.00 & 300.00 & 0.02 & 0.93 & 47.31 & 48.26 & 1.57 & 128.00 \\
\hline & & $\cdot$ & & & & & & \\
\hline & & & & \multicolumn{2}{|c|}{ Total NOx Generated } & & & \\
\hline & & & & \multicolumn{2}{|c|}{$(\mathrm{mM} / 130 \mathrm{gWO})$} & & & \\
\hline & $\dot{-}$ & & & & & & & \\
\hline & & & Slage I & Stage II & Stage III & Total & & \\
\hline \multirow{2}{*}{ T94-HCOOH-Base1 } & 448.00 & 300.00 & 16.21 & 62.24 & 0.78 & 79.95 & & \\
\hline & & & & & & & & \\
\hline T94+HCOOH.Base2 & 465.00 & 300.00 & 10.75 & 64.15 & 0.66 & 79.09 & & \\
\hline \multirow[t]{6}{*}{ T94-HCOOH-Base3 } & 347.00 & 300.00 & 22.64 & 50.98 & 0.58 & 74.39 & & \\
\hline & & & & & & & & \\
\hline & & & . & \multicolumn{2}{|c|}{ Total CO2 Generated } & & & \\
\hline & & & & \multicolumn{2}{|c|}{ (mM/130gWO } & & & \\
\hline & & & & & & & & \\
\hline & & & Stage I & Stage II & Stage III & Total & & \\
\hline \multirow{2}{*}{ T94-HCOOH-Base1 } & 448.00 & 300.00 & 164.58 & 90.43 & 151.50 & 460.94 & & \\
\hline & & & & & & & & \\
\hline T94-HCOOH-Base2 & 465.00 & 300.00 & 154.77 & 108.11 & 139.70 & 475.05 & & \\
\hline \multirow[t]{7}{*}{ T94-HCOOH.Base3 } & 347.00 & 300.00 & 172.92 & 95.93 & 132.16 & 422.16 & & \\
\hline & & & & & & & & \\
\hline & & & & \multicolumn{2}{|c|}{ Total N2O Generated } & & & \\
\hline & & & & \multicolumn{2}{|c|}{$(\mathrm{mM} / 130 \mathrm{gWO})$} & & & \\
\hline & & & & & & & & \\
\hline & & & Stage I & Stage II & Stage III & Total & & \\
\hline & & & & & & & & \\
\hline T94-HCOOH-Base1 & 448.00 & 300.00 & 2.66 & 10.49 & 1.43 & 15.23 & & \\
\hline T94-HCOOH-Base2 & 465.00 & 300.00 & 2.15 & 14.69 & 1.31 & 26.47 & & \\
\hline & & & & & & & & \\
\hline T94-HCOOH.Base3 & 347.00 & 300.00 & 4.97 & 13.66 & 1.29 & 20.51 & & \\
\hline
\end{tabular}


Table 5.1.2 - Peak Offgas Generation Rates per 130gWO/L for the Baseline Tests

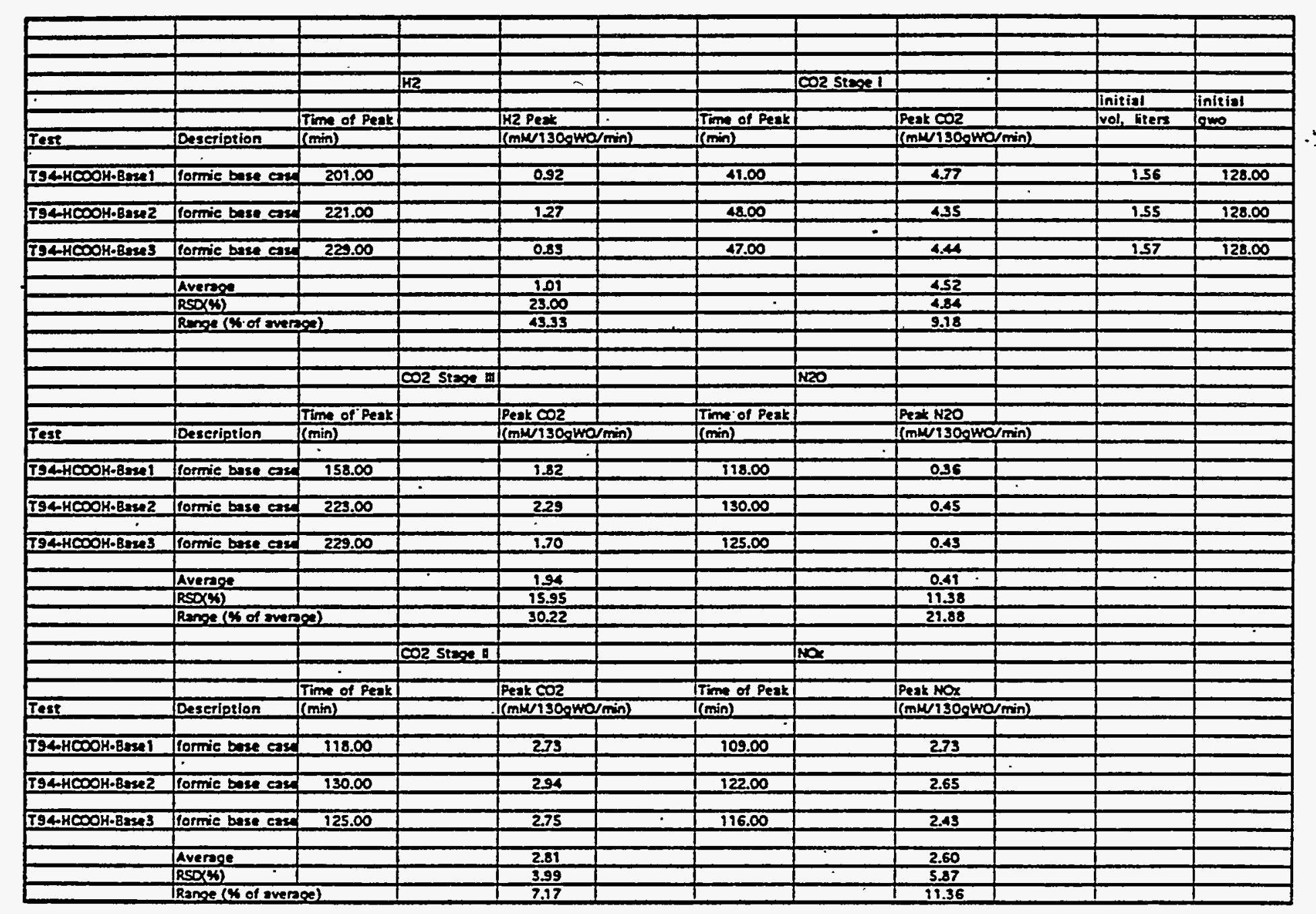


representing the entire test. Hence for purposes of comparison Test HCOOH-BASE-1 provides the best direct comparison while the other two results indicate the affects of two relatively small variations in the basic flowsheet with formic acid.

The results of the three formic acid tests, in general, appeared suitable for making an evaluation of alternate reductant tests, particularly since the reproducibility was good for most of the species and the range of values observed could be used as an upper and lower limit for comparing with measurements of offgas for a single test of each of the aiternate reductants.

\subsection{Altemate Flowsheet Waste Slurru Results}

The four alternate reductants selected for evaluation were lactic, citric, glycolic and oxalic acids. The basis for selection of these reductants is given in Section 4. In addition, a "no reductant addition" flowsheet was also tested. For the "no reductant addition" flowsheet, nitric acid was used to adjust the melter feed rheology.

In this subsection of the report, gas generation for four alternate reductants, lactic, citric, glycolic, and oxalic acids and the no-reductant/nitric acid flowsheets are presented and compared with the baseline flowsheet, formic acid.

The offgas generation profiles for these tests are shown in Figures 5.2.1 to 5.2.5. The amounts of offgas generated and peak gas generation rates for the alternate reductant and nitric acid flowsheets are given in Tables 5.2.1 and 5.2.2, respectively. These data were derived from the data description provided in Appendix A. The values were normalized to $130 \mathrm{gWO}$ for comparison purposes. The four gases observed were $\mathrm{H}_{2}, \mathrm{CO}_{2}, \mathrm{NO}_{x}$, and $\mathrm{N}_{2} \mathrm{O}$. Total measured $\mathrm{NH}_{3}$, based on slurry and condensate analyses is also presented below.

The total elapsed time for each test, the duration of the period for which the total gas release was calculated (Stage III Ending .Time), the amount of gas released for each stage, and the total amount of each gas measured for each test are listed in Table 5.2.1. The average gas releases for the three replicate formic acid tests are given in Table 5.1.1 as a basis for comparison.

\section{$52 . \mathrm{L} \mathrm{H}_{2}$ Generation}

Hydrogen was observed only when processing with formic acid and a small amount during a process test with glycolic acid ( $-1 / 100$ th the total amount compared with the formic acid flowsheet) see Figure 5.3.1. Hydrogen was not observed during processing with lactic, citric, oxalic and nitric acids and was so low in the glycolic acid test that it does not show in Figure 5.2.4.

The $\mathrm{H}_{2}$ generation rate for the reference formic acid flowsheet, $\sim 1.0 \mathrm{mM} / \mathrm{min}$, was several orders of magnitude greater than the peak rate detected for the glycolic acid process test in which $\mathrm{H}_{2}$ was observed. Hydrogen was not observed in the other altemate reductant process flowsheets tested.

\section{2 .2 Total Measured $\mathrm{NH}_{3}$}

The amounts of measured $\mathrm{NH}_{3}$ for the alternate reductant tests were very small and likely represent tramp amounts. From the measured amounts and comparable results obtained from the formic acid tests the conclusion was that, within experimental error, very little $\mathrm{NH}_{3}$ was produced using any of the altemate reductants under the conditions tested. 
BVTD-C95-02.02K, Rev. 0

Page 30 of 45

Offgas Generation CITRIC - 1

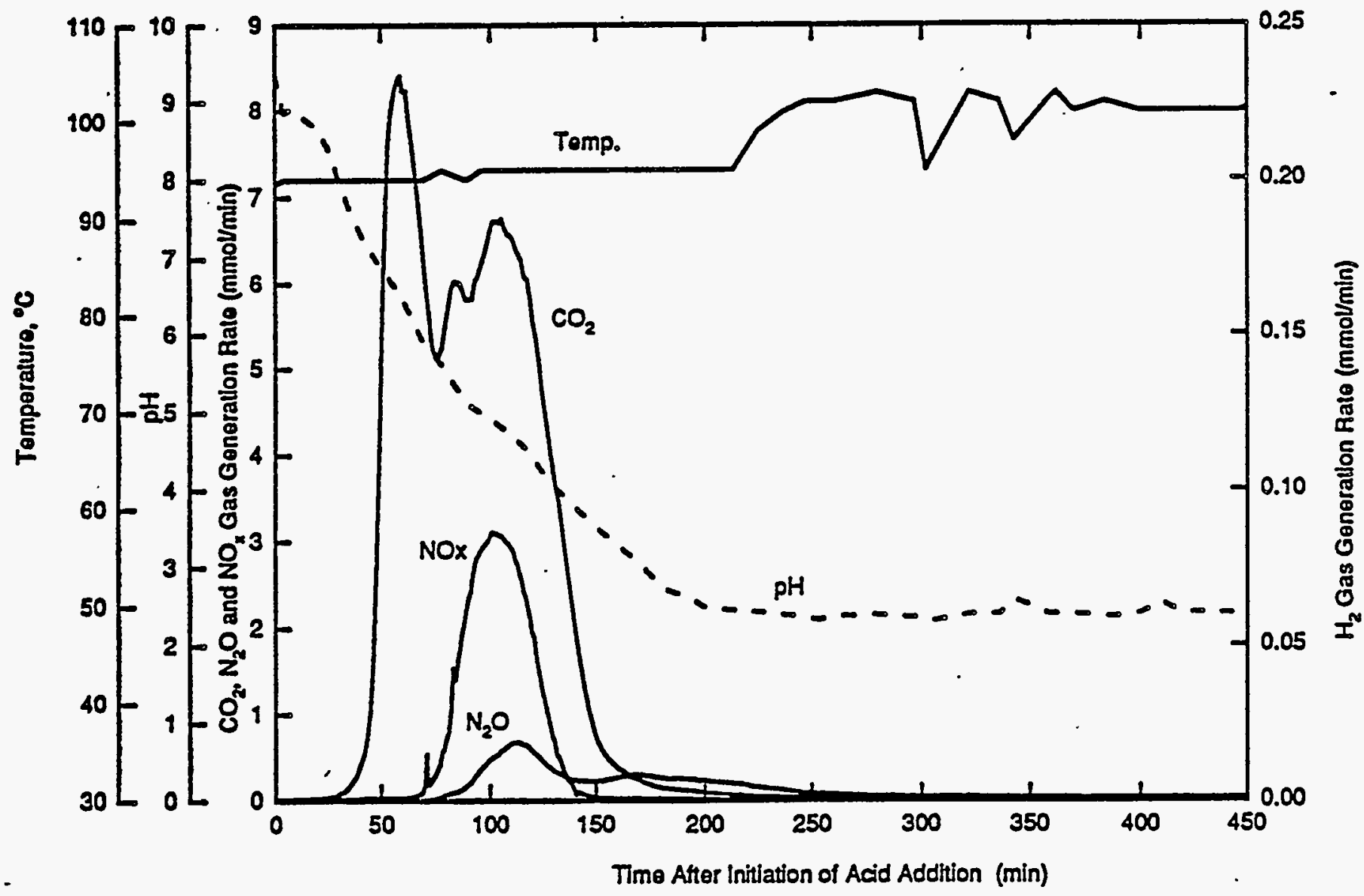

Figure 5.2.1 - Offgas Profiles from Test T94-CITRIC-1 Covering the First 450 Minutes after the Initiation of Citric Acid Addition. Temperature, $\mathrm{pH}, \mathrm{CO}_{2}, \mathrm{NO}_{x}$, and $\mathrm{N}_{2} \mathrm{O}$ profiles are shown. $\mathrm{No}_{2}$ was detected. 
Offgas Generation GLYCOLIC - 1

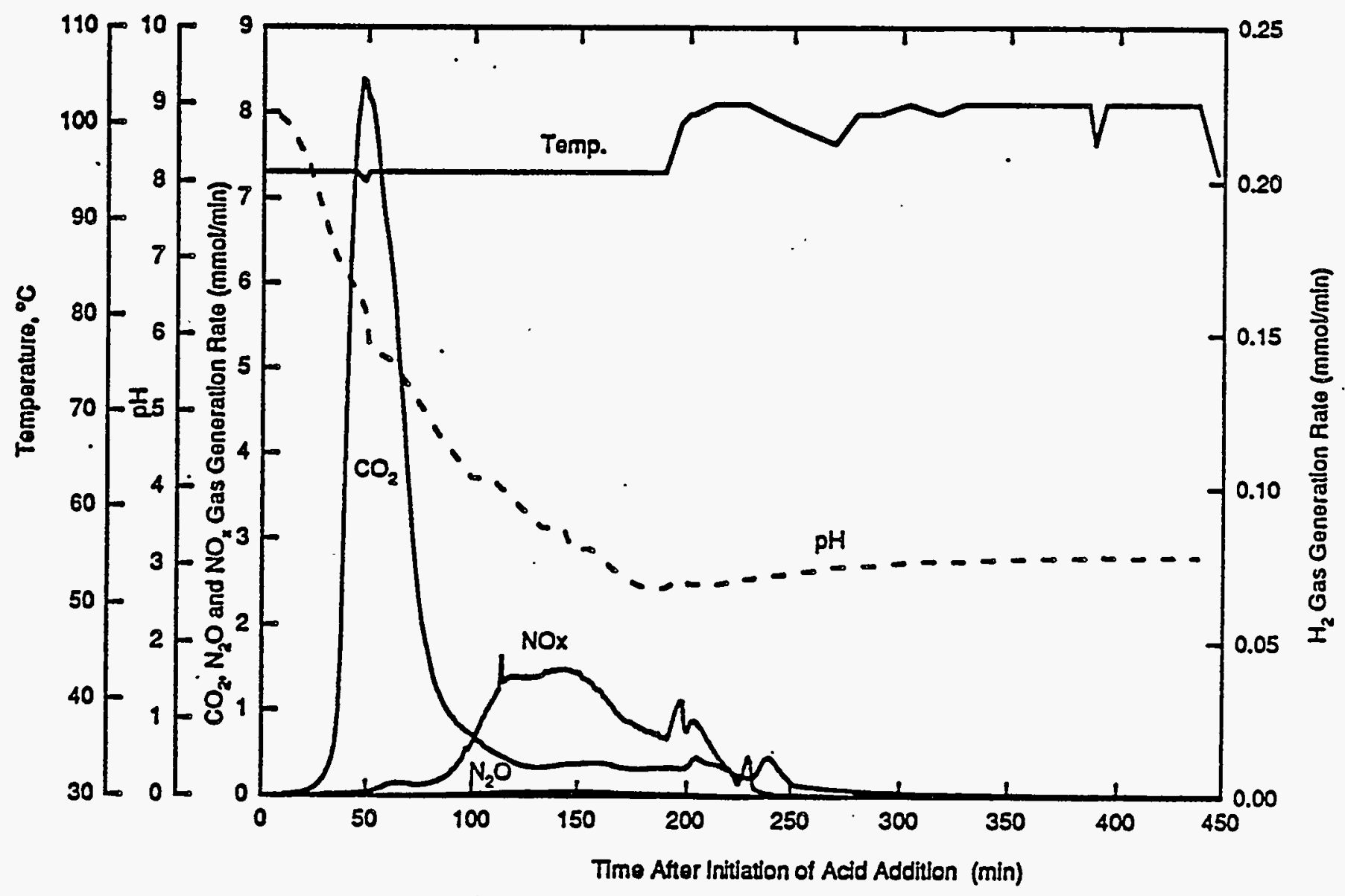

Figure 5.2.2 - Offigas Profiles from Test T94-GLYCOLIC-1 Covering the First 450 Minutes after the Initiation of Glycolic Acid Addition. Temperature, $\mathrm{pH}, \mathrm{CO}_{2}, \mathrm{NO}_{x}$, and $\mathrm{N}_{2} \mathrm{O}$ profiles are shown. $\mathrm{H}_{2}$ was detected but was not plotted. 
PVTD-C95-02.02K, Rev. 0

Page 32 of 45

Offgas Generation LACTIC - 1

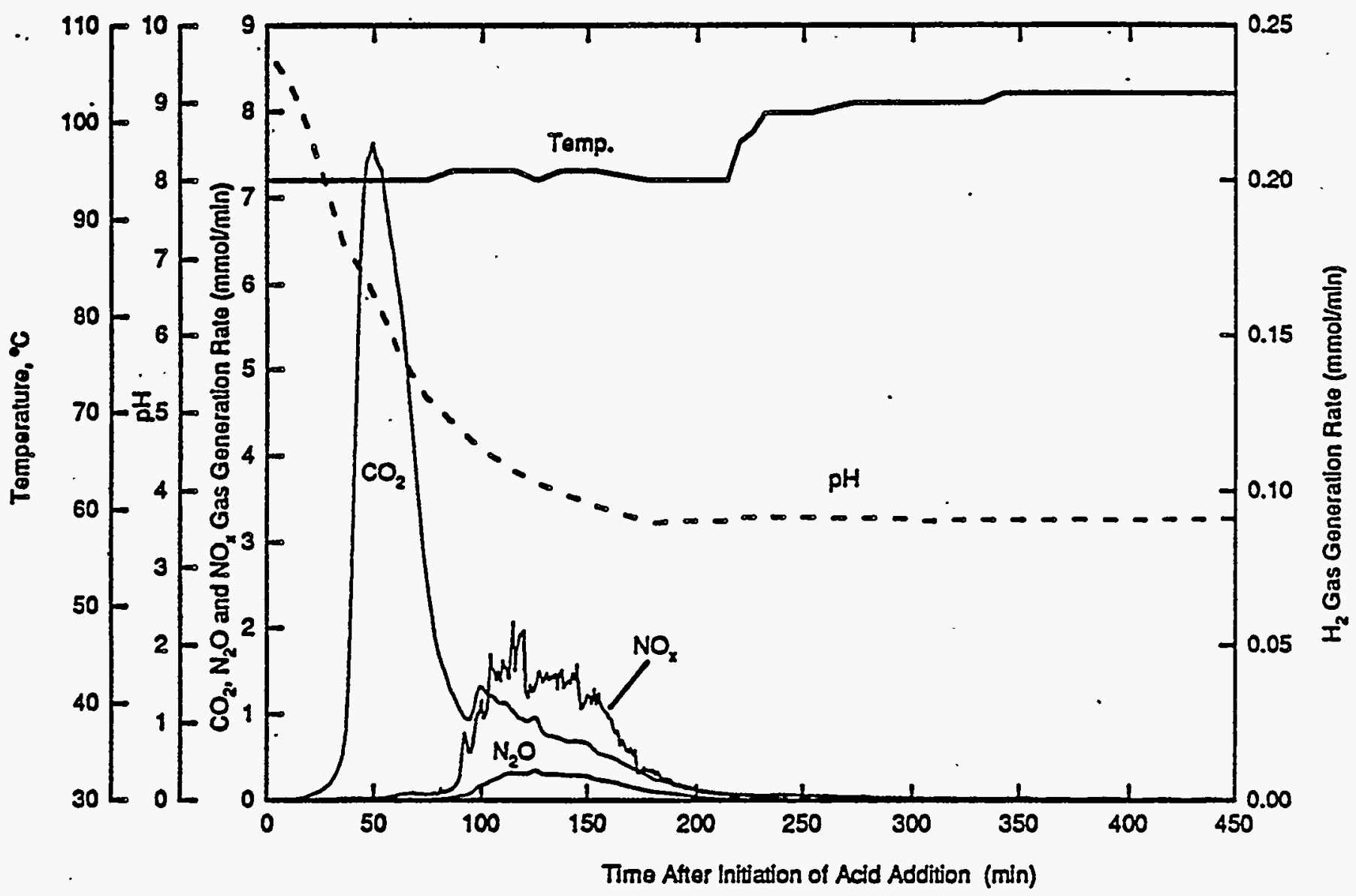

Figure 5.2.3 - Offgas Profiles from Test T94-LACTIC-1 Covering the First 450 Minutes after the Initiation of Lactic Acid Addition. Temperature, $\mathrm{pH}, \mathrm{CO}_{2}, \mathrm{NO}_{x}$, and $\mathrm{N}_{2} \mathrm{O}$ profiles are shown. No $\mathrm{H}_{2}$ was detected. 
Offgas Generation T94 Oxalic - 1

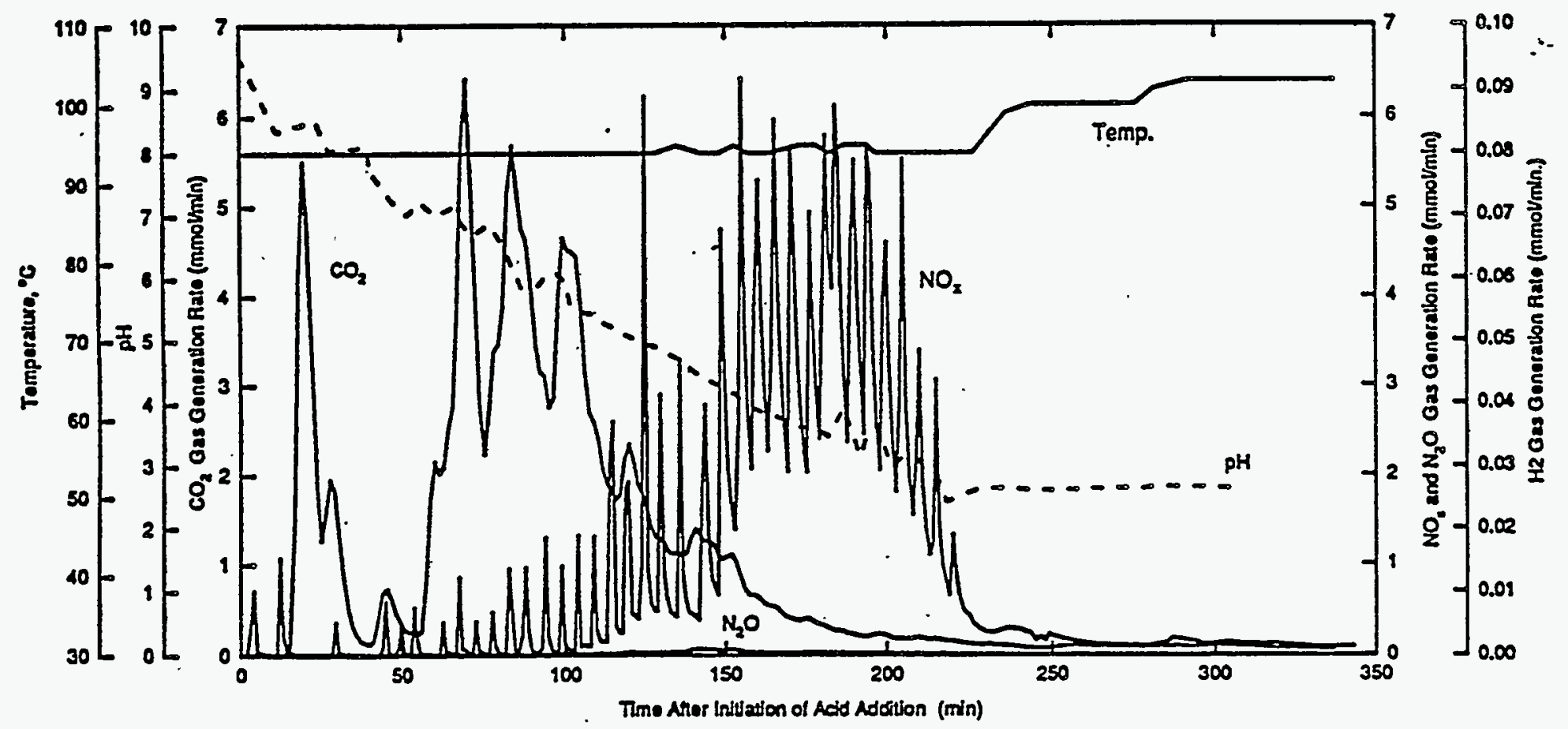

Figure 5.2.4 - Offgas Profiles from Test T94-OXALIC-1 Covering the First 350 Minutes after the Initiation of Oxalic Acid Addition. Temperature, $\mathrm{pH}, \mathrm{CO}_{2}, \mathrm{NO}_{x}$, and $\mathrm{N}_{2} \mathrm{O}$ profiles are shown. No $\mathrm{H}_{2}$ was detected. 
Offgas Generation T94 - HNO $3-1$

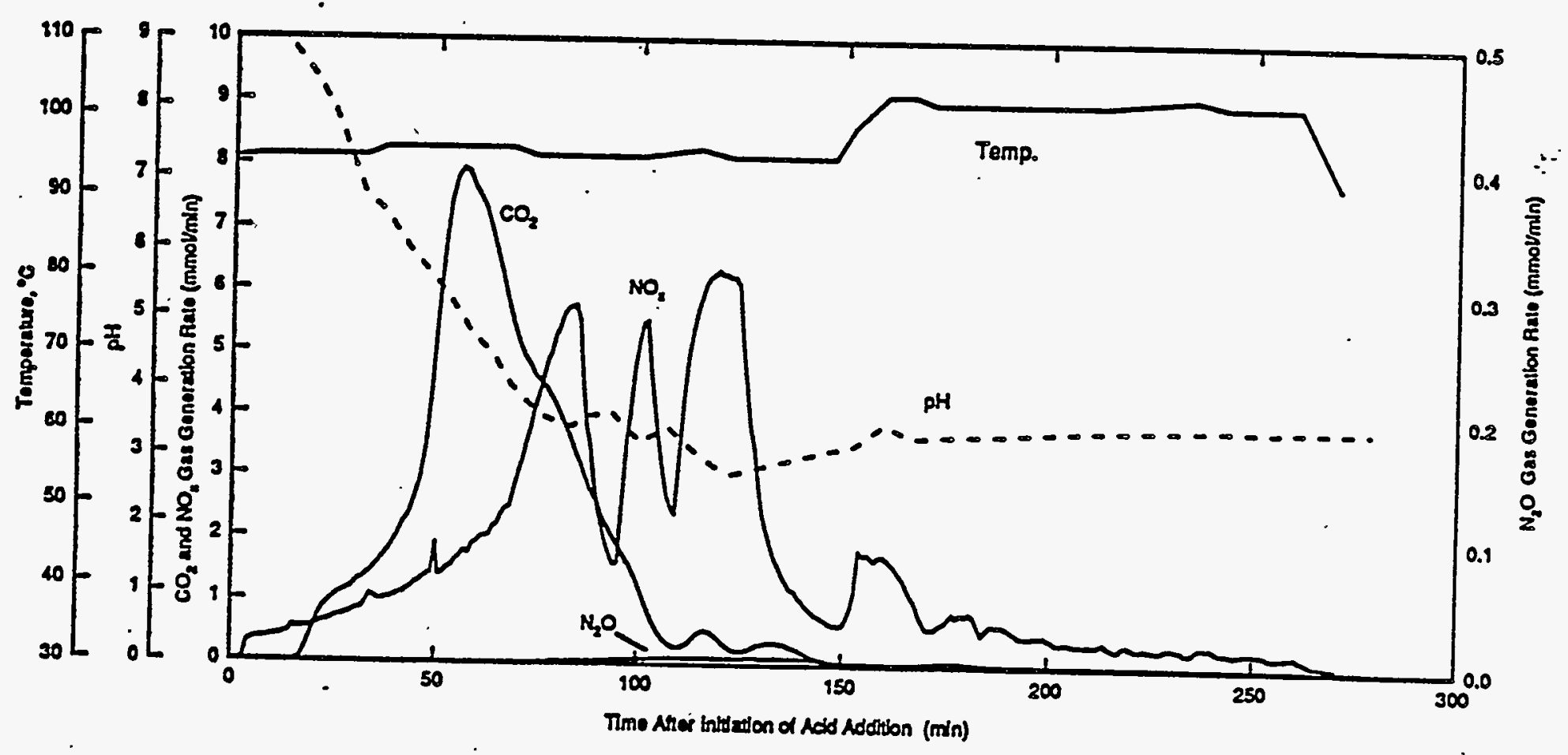

Figure 5.2.5 - Offgas Profiles from Test T94-HNO3-1 Covering the First 300 Minutes after the Initiation of Nitric Acid Addition. Temperature, $\mathrm{pH}, \mathrm{CO}_{2}, \mathrm{NO}_{\mathrm{x}}$, and $\mathrm{N}_{2} \mathrm{O}$ profiles are shown. No $\mathrm{H}_{2}$ was detected. 
Table 5.2.1 - Offgas Generated per 130gWO/L for the Alternate Flowsheet Tests

\begin{tabular}{|c|c|c|c|c|c|c|c|c|c|c|c|c|}
\hline & & & & TTan K2 $\mathrm{Gon}$ & & & & Tod $\cos \mathrm{C}$ & and & & & \\
\hline & Toral Toen & sepen & & (m) & & & & $\operatorname{lom}(\mathrm{W} / 30 \mathrm{gN}$ & & & & \\
\hline Font & Iime & Ending Time & & & & & & & & & & \\
\hline & $(\min )$ & $(\min )$ & Sيnol & sines & seeill & Tonal & sisen 1 & sisel & Secen II & Tonal & insial vol & lin stron \\
\hline & & & & & & & & & & & & \\
\hline 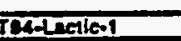 & 415.00 & 300.00 & 0.00 & 0.00 & 0.00 & 0.00 & 152.15 & 07.08 & 2.15 & 200.84 & 1.57 & 128.00 \\
\hline Ty-chriat & 480.00 & 300.00 & 0.00 & 0.00 & 0.00 & 0.00 & 122.18 & 247.90 & 9.24 & 380.05 & 1.48 & 195.00 \\
\hline & & & & & & & & & & & & \\
\hline Telabreoticol & 240.00 & 300.00 & 0.00 & 0.00 & 0.00 & 0.00 & 151.06 & 30.33 & 2.03 & 208.07 & 1.58 & 122.00 \\
\hline Tesefpalyeorion & 390.00 & 220.00 & 0.03 & 0.40 & (a) & 0.53 & 138.22 & 21.33 & (a) & 150.56 & 1.75 & 140.00 \\
\hline 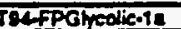 & 243.00 & 243.00 & 0.04 & 0.01 & 0.58 & 0.63 & 963.16 & 67.64 & 21.18 & 252.68 & 0.75 & 225.00 \\
\hline & & & & & & & & & & & & \\
\hline $\mathrm{TQPANOS-1}$ & 227.00 & 277.00 & 0.00 & 0.00 & 0.00 & 0.00 & (a) & (a) & (a) & 127.15 & 1.52 & $1<1.00$ \\
\hline Teroxalin-1 & 337.00 & 300.00 & 0.00 & 0.00 & 0.00 & 0.00 & (a) & (a) & 201.27 & 206.26 & 1.48 & 146.00 \\
\hline$T \times+\left.P O x\right|_{x=1}$ & 24.00 & 24.00 & 0.00 & 0.00 & 0.00 & 0.00 & (0) $>>$ & (a) & 358.22 & 351.22 & 1.74 & 151.00 \\
\hline 2 no idemisolo it & & & & & & & & 些 & 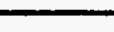 & & $x_{-1}$ & \\
\hline & & & & & & & & & & & & \\
\hline & & & & & & & & & & & & \\
\hline Anope $81,82,89$ & & & 0.01 & 0.73 & $\frac{53.94}{10.18}$ & 57.09 & $\frac{184.08}{5.34}$ & $\frac{92.18}{9.23}$ & $\frac{141.12}{8.91}$ & $\frac{452.72}{8.05}$ & & \\
\hline $250(x)$ & & & 173.21 & 11.60 & 10.40 & 25.15 & 5.54 & 2.22 & 8.81 & 0.05 & & \\
\hline & & & & & & & & & & & & \\
\hline An . bo Stage 1 & & & & 0.10 & & & & 262.25 & & & & \\
\hline R50(x) & & & & 19.62 & & & & 2.65 & & & & \\
\hline & & & & & & & & & & & & \\
\hline Ave. $102 \mathrm{l}$ a $300 \mathrm{~min}$ & & & & & 54.14 & & & & 009.37 & & & \\
\hline ASO (x) & & & & & 9.98 & & & & 0.70 & & & \\
\hline $\operatorname{Rames}(x)$ & & & & & 19.57 & & & & 1.38 & & & \\
\hline & & & & & & & & & & & & \\
\hline & & & & TOdNOS GM & & & & Toul NoO G & rised & & & \\
\hline & Total Ted & sucelli & & $1(\mathrm{~mL} / 130 \mathrm{~g} / \mathrm{O}$ & & & & I(mL/130 ow & & & & \\
\hline Tost. & $\pi \operatorname{in} e$ & Encing Time & & & & & & & & & & \\
\hline & $(\min )$ & $(\min )$ & singe 1 & sincox & $\operatorname{singe} 10$ & Total & Steot & Shas I & S20011 & Toral & & \\
\hline & & & & & & & & & & & & \\
\hline TQA-Luetice? & $\$ 15.00$ & 300.00 & 3.72 & 88.16 & 0.97 & 73.20 & 0.50 & 15.02 & 0.52 & 10.11 & & \\
\hline & & & & & & & & & & & & \\
\hline Teanclurie 1 & 469.00 & 300.00 & 1.86 & 70.04 & 0.13 & 11.20 & 0.09 & 5.28 & 0.31 & 6.18 & & \\
\hline TOL-Giyes lic.1 & 449.00 & 300.00 & 2.88 & 10.92 & 0.30 & 03.40 & 0.05 & 3.65 & 0.08 & 3.71 & & \\
\hline & & & & & & & & & & & & \\
\hline 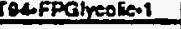 & 330.00 & 290.00 & 0.08 & 20.52 & (a) & 40.86 & 0.12 & 1.42 & (a) & 2.18 & & \\
\hline Tefpamedic-12 & 243.00 & 243.00 & 94.71 & 13.20 & 37.44 & 135.15 & 0.58 & 4.90 & 5.00 & 10.55 & & \\
\hline TarunOT- & & & & (1) & & $x=\frac{T}{2}$ & $\mathrm{l}^{2} \mathrm{~h}$ & & & & & \\
\hline Ispanos.1 & 277.00 & 277.00 & (a) & (a) & (a) & 258.12 & (a) & (a) & (1) & 0.11 & & \\
\hline Peroralie 1 & 337.00 & 300.00 & (a) & (a) & 184.24 & 188.03 & (a) & (ㅇ) & 2.64 & 2.64 & & \\
\hline ToffPOxalic-1 & 248.00 & 248.00 & (a) & (2) & 29.55 & 28.53 & (a) & (a) & 1.28 & 1.29 & & \\
\hline & & & & & & & & & & & & \\
\hline 1 oo identriente on & & & & & & & & & & & & \\
\hline & & & & & & & & & & & & \\
\hline Avrage Bl,B2,B3 & & & 18.53 & 59.12 & 0.67 & 77.81 & 3.26 & 12.95 & 1.35 & 20.74 & & \\
\hline $950(x)$ & & & 38.01 & 12.04 & 18.96 & 3.84 & 46.21 & 16.81 & 5.62 & 27.11 & & \\
\hline & & & & & & & & & & & & \\
\hline Ave. bi sigol of & & & & 73.65 & & & & 16.21 & & & & \\
\hline RSD $(x)$ & & & & 3.31 & & & & 17.24 & & & & \\
\hline & & & & & & & & & & & & \\
\hline Ave. totd $0300 \mathrm{~min}$ & & & & & 76.39 & & & & 17.55 & & & \\
\hline ASO $(x)$ & & & & & 3.49 & & & & 15.50 & & & \\
\hline anseg(x) & & & & & 8.58 & & & & 30.43 & & & \\
\hline
\end{tabular}


Table 5.2.2 - Peak Offgas Generation Rates per $130 \mathrm{gWO} / \mathrm{L}$ for the Altemate Flowsheet Tests

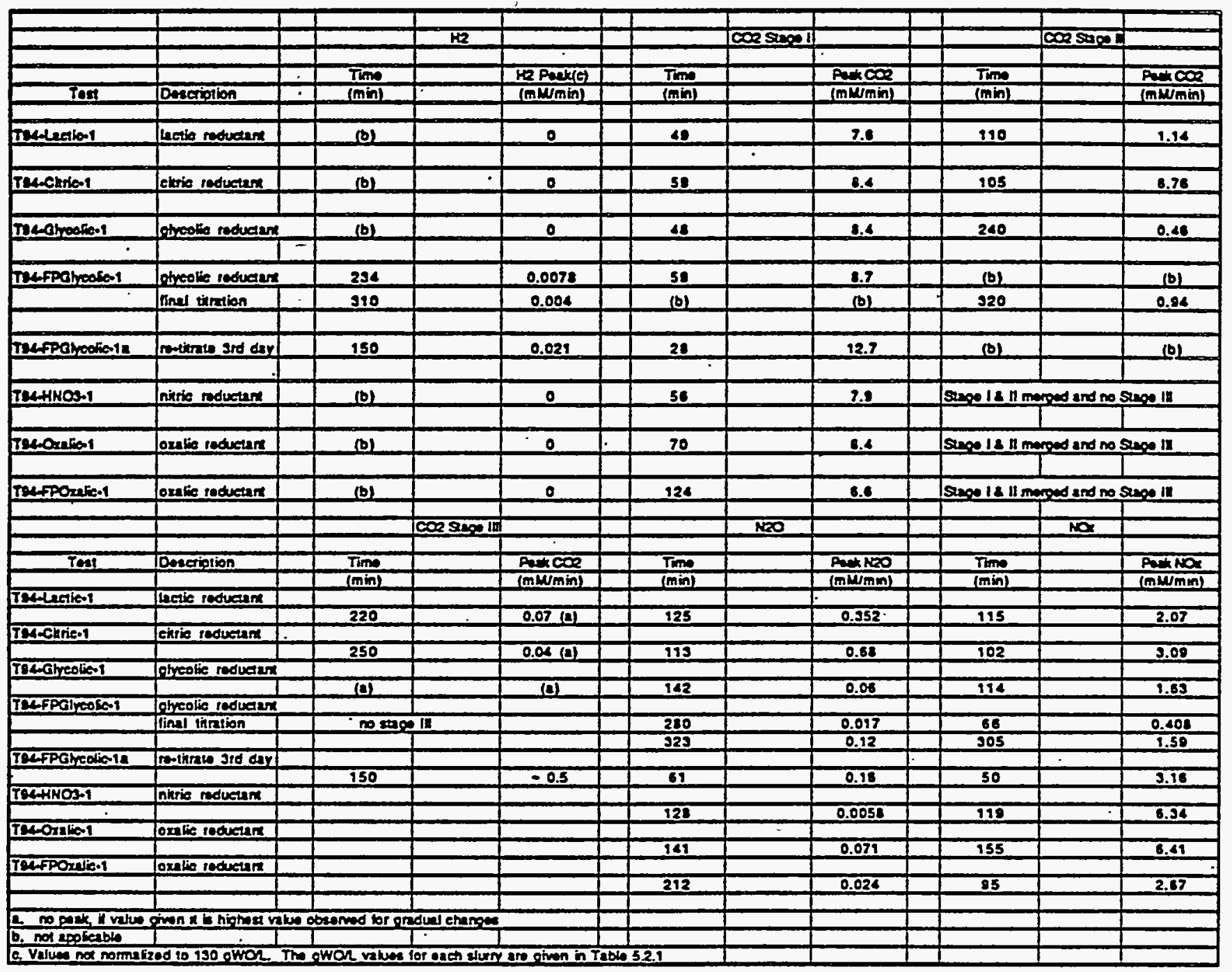




\section{$5.2 .3 \mathrm{CO}_{2}$ Generation}

The highest peak $\mathrm{CO}_{2}$ generation occurred during stage I. The stage I peak $\mathrm{CO}_{2}$ generation rate varied from 6.4 to $8.4 \mathrm{mM} / \mathrm{min}$ for the altemate reductants, nitric acid and formic acid reference flowsheets; the highest rates being observed with glycolic and citric acids.

The amount of $\mathrm{CO}_{2}$ evolved is compared for each stage, except for the nitric acid and oxalic acid flowsheets where transition from Stage I to II was not well defined. Within experimental error, the amount of $\mathrm{CO}_{2}$ released during Stage I was consistent with decomposition of carbonic acid, based on the target amount of carbonate added (130 mmole of carbonate per $130 \mathrm{gWO}$ ). The average Stage I $\mathrm{CO}_{2}$ evolution for the three formic acid tests was 164 mmoles $/ 130 \mathrm{gWO}$, or about $25 \%$ higher than the amount of carbonate. The extra $\mathrm{CO}_{2}$ can be attributed to the reduction of $\mathrm{MnO}_{2}$ (Equation 8) which would produce an additional 32 mmoles $/ 130 \mathrm{~g} . W 0$. The amounts of $\mathrm{CO}_{2}$ during Stage I for the various reductants were about the same as for the formic acid tests, see Table 5.2.1.

The total amount of $\mathrm{CO}_{2}$ produced during processing was dependent on the type of reductant added and the presence of stage III reactions, i.e., production of $\mathrm{H}_{2}$ and $\mathrm{NH}_{3}$. The total amount of $\mathrm{CO}_{2}$ produced during processing with the lactic, glycolic, oxalic and nitric acids (187 to 201 $\mathrm{mM} / 130 \mathrm{gWO}$ ) was less than that observed for stages I and II of the formic acid flowsheet, -262 $\mathrm{mM} / 130 \mathrm{gWO}$. Note that the equivalents of oxalic acid added was higher than for the formic acid tests (1.8 vs 1.6 acid equiv/130 $\mathrm{gWO}$ ), which probably increased the amount of $\mathrm{CO}_{2}$ somewhat. Stages $I$ and $\Pi$ only are used for comparison in this case, as little to no $\mathrm{H}_{2}, \mathrm{NH}_{3}$ and associated $\mathrm{CO}_{2}$ generation were observed during processing with these additives.

The total amount of $\mathrm{CO}_{2}$ produced during processing with citric acid was greater than that observed for the baseline formic acid tests stages I and II ( 376 compared with $262 \mathrm{mM} / 130 \mathrm{gWO}$ ); but somewhat less than the total $(403 \mathrm{mM} / 130 \mathrm{gWO}$ ) for the baseline formic acid flowsheet (including stage III to 300 minutes).

The peak generation rates of $\mathrm{CO}_{2}$ for the altemate reductants (stage I) were about the same as for the formic acid baseline tests. All were somewhat higher with the greatest deviation being $22 \%$ higher for glycolic acid, see Table 5.2.2.

\section{$5.2 .4 \mathrm{NO}_{\mathbf{x}}$ Generation}

The total $\mathrm{NO}_{\mathrm{x}}$ generated for lactic, citric and glycolic acid reductants was about the same as for the baseline formic acid tests, with the greatest difference being glycolic acid, $94 \mathrm{mM} / 130 \mathrm{gWO}$ compared to an average of $78 \mathrm{mM} / 130 \mathrm{gWO}$ for the three formic acid baseline tests. The peak $\mathrm{NO}_{\mathrm{x}}$ generation rates were less than that observed for the reference formic acid flowsheet $(4.0 \mathrm{mM} / \mathrm{min})$, with the exception of the nitric acid flowsheet. During processing with nitric acid, the $\mathrm{NO}_{\mathrm{x}}$ peak generation rate was $6.3 \mathrm{mM} / \mathrm{min}$, or a factor of 1.6 greater than that measured for the reference formic acid flowsheet. The peak $\mathrm{NO}_{x}$ generation rates for the tests with lactic, citric and glycolic acids were in general lower than for the baseline formic acid tests (in the range of $40 \%$ to $80 \%$ of the baseline values, see Table 5.2.2).

A comparison of the amount generated for Test T94-OXALIC-1 and Test T94-HNO3-1 compared to the baseline tests was not appropriate because the $\mathrm{NO}_{2}{ }^{-}$and $\mathrm{NO}_{3}{ }^{\circ}$ concentrations and amounts of acid added were different. Instead, a comparison was made with a comparable formic acid test (Test 1.01) performed in FY 1992 (Smith et al. 1995) for comparison with the oxalic acid test. The relative amounts were $184 \mathrm{mM} / \mathrm{gWO}$ for the oxalic test compared to about $270 \mathrm{mM} / 130 \mathrm{gWO}$ 
for the most directly comparable formic acid test (Test 1.02). The nitric acid test produced 257 $\mathrm{mM} / 130 \mathrm{gWO}$, which was higher than the comparable formic acid test, $207 \mathrm{mM} / 130 \mathrm{gWO}$ (Test SIPTnm, Smith et al. 1995). The peak $\mathrm{NO}_{x}$ generation rate for oxalic was $6.4 \mathrm{mM} / \mathrm{min}$, or about $90 \%$ of the peak for the comparable formic acid test (Test 1.02 Smith et al. 1995), and was 6.3 $\mathrm{mM} / \mathrm{min}$ for the nitric acid test, or about $183 \%$ of the peak rate for the comparable formic acid test (Test 1.16b, Smith et al. 1995).

\section{$5.2 .5 \mathrm{~N}_{2} \mathrm{O}$ Generation}

The total $\mathrm{N}_{2} \mathrm{O}$ generated for lactic, citric and glycolic tests depended on the type of reductant and was less than the baseline formic acid tests. For oxalic acid, the total $\mathrm{N}_{2} \mathrm{O}$ was $2.6 \mathrm{mM} / 130$ $\mathrm{gWO}$ compared to $20 \mathrm{mM} / 130 \mathrm{gWO}$ for formic acid. For nitric acid, essentially no $\mathrm{N}_{2} \mathrm{O}$ was generated compared to $34 \mathrm{mM} / 130 \mathrm{gWO}$ for a formic acid flowsheet (Test 1.16b, Smith et al. 1994) under comparable conditions.

The peak $\mathrm{N}_{2} \mathrm{O}$ generation rates depended on the type of reductant and were equal to or less than that observed for the baseline formic acid flowsheet $(0.63 \mathrm{mM} / \mathrm{min})$. The lowest $\mathrm{N}_{2} \mathrm{O}$ generation rates were observed during processing with nitric acid $(<0.01 \mathrm{mM} / \mathrm{min})$. The peak $\mathrm{N}_{2} \mathrm{O}$ generation rate for lactic acid was lower ( $-56 \%$ ), for citric acid it was about the same ( $8 \%$ higher), and for glycolic acid it was lower ( $10 \%)$. A comparison of the peak $\mathrm{N}_{2} \mathrm{O}$ generation rates for oxalic acid and nitric acid with earlier tests (Smith et al. 1994) indicated much smaller amounts for these two acids,

\subsection{Altemate Flowsheet Meiter Feed Slumy Results}

The extensive offgas evaluation of the altemate flowsheets showed that all of the candidates produced little or no $\mathrm{NH}_{3}$ and $\mathrm{H}_{2}$. This was predicted by previous University of Georgia studies and the reason the four were selected for this evaluation from a larger group. (Thirteen altemate reductant candidates were screened in a series of laboratory tests by $\mathrm{Dr}$. R. B. King and his associates at the University of Georgia to evaluate the potential for $\mathrm{H}_{2}$ and $\mathrm{NH}_{3}$ generation during treatment of a simplified NCAW simulant.16) However, this left too many candidates to be evaluated and a down selection to oxalic acid, nitric acid, and glycolic acid was made on the basis of redox considerations. The HTM will produce a more reduced melt because of the higher temperatures envolved and make it uncertain what level of reduction will be most beneficial in the melter cold cap during melter operation. Therefore, the three altemate flowsheets (oxidizing to reducing) were taken to the meiter feed make up step to see if they would produce a melter feed slurry with both an acceptable theology for pipe transferes from mixing tanks to the melter and have an acceptable total oxide loading

Previously processed waste slurries were processed with excess acid to accentuate any tendency for $\mathrm{NH}_{3}$ or $\mathrm{H}_{2}$ formation and were therefore not suitable for melter feed fabrication. Hence, the three candidate acids were used to make melter feeds with an acceptable level of acidity. (There is no need for excess acid since it does not improve the theology to lower the pH below about 6 and adds additional offgas volume.) These tests were coducted using the same flowsheet procedures but onily enough acid was added to lower the $\mathrm{pH}$ to less than 5 allowing for some $\mathrm{pH}$ rebound. The offgas profiles shown in Figures 5.3.1 to 5.3.3 show that the offgas profiles for feed preparation were essentially the same as for the original screening for $\mathrm{NH}_{3}$ and $\mathrm{H}_{2}$ production. The offgas data is is summarized in Tables 5.3.1 and 5.3.2. These slurries were made into melter feeds by concentrating them to about $225 \mathrm{gWO} / \mathrm{L}$ and then added the glass components silica and sodium oxide (as sodium

16R.B. King, N.K. Bhattacharyya, and V. Kumar. December 1993, Monthly Technical Report,: "Hanford Waste Vitrification Plant Hydrogen Study: Preliminary Evaluation of Altematives to Formic Acid." Prepared for Pacific Northwest Laboratory under contract number 125770-A-A2. 
Offgas Generation T94 FP Glyc-1

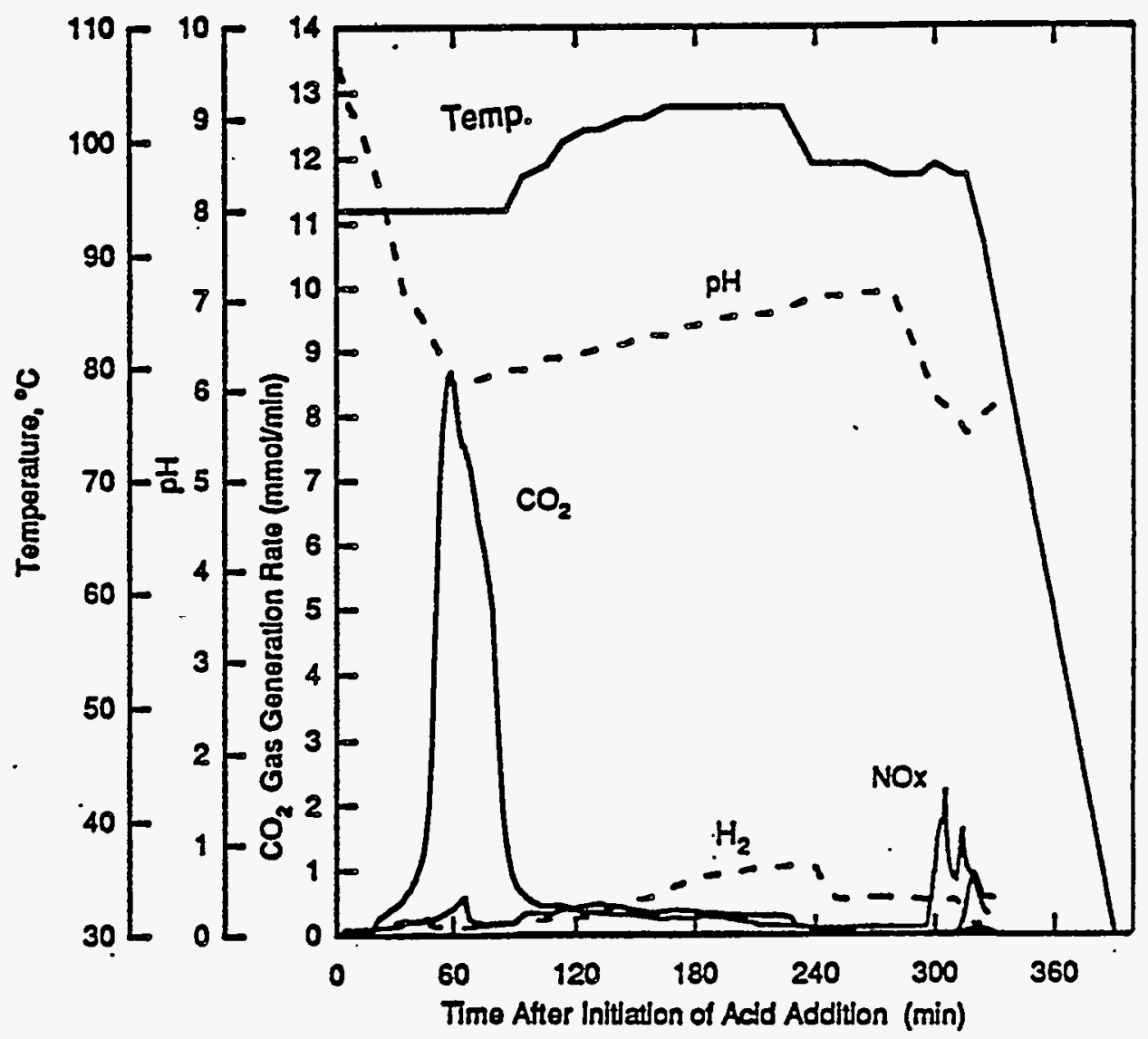

Figure 5.3.1 - Offgas Profiles from Feed Preparation Test T94-FPGLYC-1 Covering the First 250. Minutes after the Initiation of Glycolic Acid Addition. Temperature, $\mathrm{pH}$ $\mathrm{CO}_{2}, \mathrm{NO}_{x}$, and $\mathrm{N}_{2} \mathrm{O}$ profiles are shown. $\mathrm{H}_{2}$ was detected as indicated on the plot. 


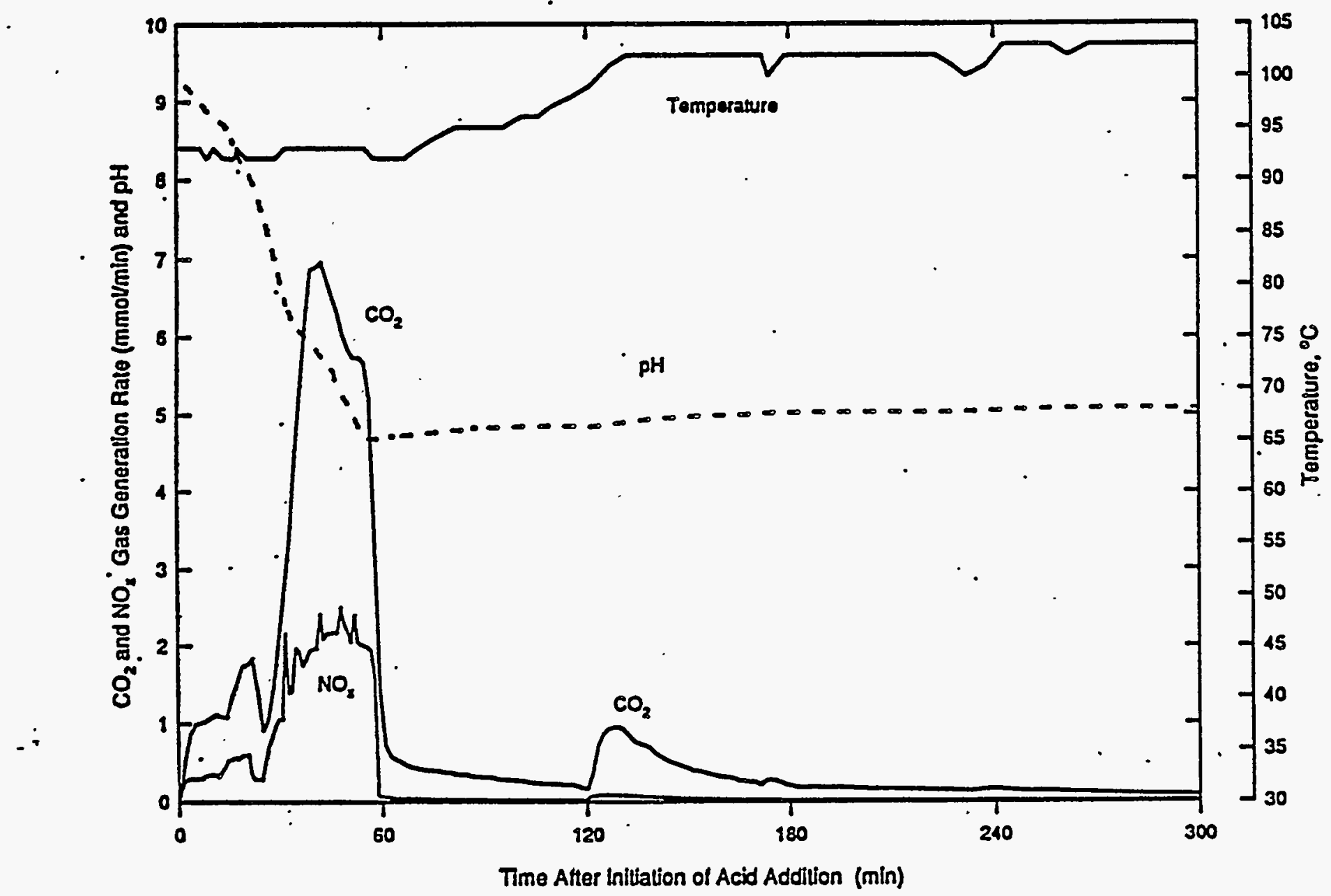

Figure 5.3.2 - Offgas Profiles from Feed Preparation Test T94-FPHNO3-1 Covering the First 300 Minutes after the Initiation of Nitric Acid Addition. Temperature, $\mathrm{pH}, \mathrm{CO}_{2}$, $\mathrm{NO}_{x}$, and $\mathrm{N}_{2} \mathrm{O}$ profiles are shown. $\mathrm{No}_{2}$ was detected. 


\section{Offgas Generation T94.FPOXAL- 1}

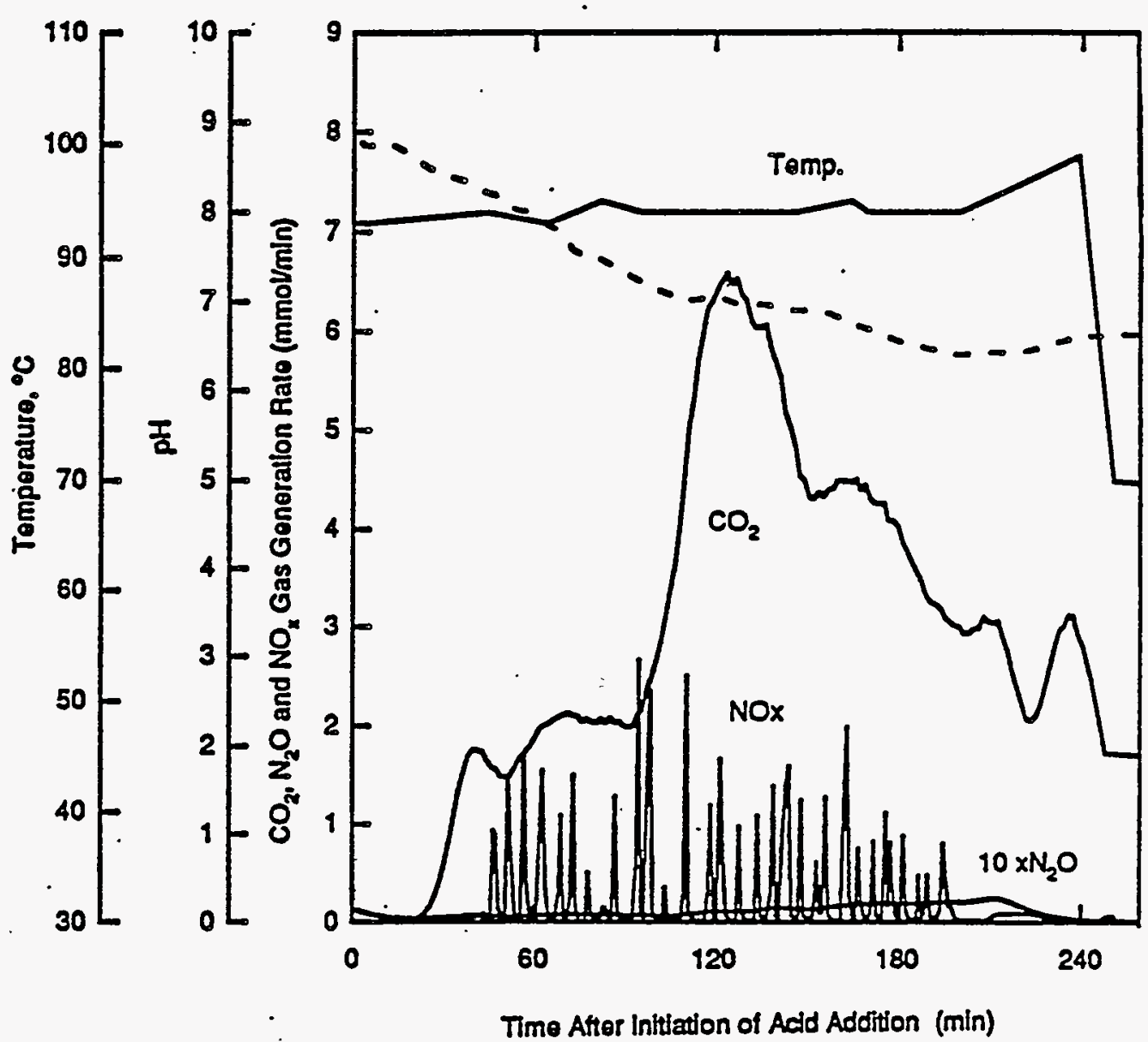

Figure 5.3.3 - O Offgas Profiles from Feed Preparation Test T94-FPOXAL-1 Covering the First 250 Minutes after the Initiation of Oxalic Acid Addition. Temperature, $\mathrm{pH}, \mathrm{CO}_{2}$, Nox, and $\mathrm{N}_{2} \mathrm{O}$ profiles are shown. No $\mathrm{H}_{2}$ was detected. 
Table 5.3.1 - Offgas Generated per 130gWO/L for the Alternate Flowsheet Melter Feed Preparation Tests

\begin{tabular}{|c|c|c|c|c|c|c|c|c|}
\hline & & & & \multicolumn{2}{|c|}{ Total H2 Generated } & & & \\
\hline & Total Test & Stage III & & \multicolumn{2}{|c|}{ (mM/130oWO) } & & & \\
\hline \multirow[t]{2}{*}{ Test } & Time & Ending Time & & & & & & \\
\hline & $(\min )$ & (min) & Stage I & Stage II & Stage III & Total & initial vol & init gWOA \\
\hline TO4fPGhycolie-1 & 330.00 & 290.00 & 0.05 & 0.48 & (a) & 0.58 & 1.75 & 140.00 \\
\hline \multirow[t]{2}{*}{ TO4FPGlycolic-1a } & 243.00 & 243.00 & 0.04 & 0.01 & 0.58 & 0.63 & 0.75 & 225.00 \\
\hline & - & & & $\dot{\square}$ & & & & \\
\hline T94-FPOxalic-1 & 248.00 & 248.00 & 0.00 & 0.00 & 0.00 & 0.00 & 1.74 & 151.00 \\
\hline \multirow[t]{4}{*}{ T95-FPHNO3-3 } & 555.00 & 555.00 & na & na & na & not detected & 1.52 & 173.00 \\
\hline & & & & & & & & \\
\hline & & & & \multicolumn{2}{|c|}{ Total NOx Generated } & & & \\
\hline & Total Test & Stage III & & \multicolumn{2}{|l|}{ (mM/130gWO) } & & & \\
\hline \multirow[t]{2}{*}{ Test } & Time & Ending Time & & & & & & \\
\hline & $(\min )$ & $(\min )$ & Stage I & Stage II & Stage III & Total & & \\
\hline \multirow[t]{2}{*}{ T94-FPG Gycolic-1 } & 330.00 & 290.00 & 8.01 & 20.32 & (a) & 40.64 & & \\
\hline & & & & & & & & \\
\hline T94-FPGlycolic-1a & 243.00 & 243.00 & 14.71 & 83.20 & 37.44 & 135.35 & & \\
\hline T94-FPOxalic-1 & 248.00 & 248.00 & (a) & (a) & 28.55 & 28.55 & & \\
\hline \multirow[t]{4}{*}{ T95-FPHNO3-3 } & 555.00 & 555.00 & na & na & na & 78.60 & & \\
\hline & & & & & & & & \\
\hline & & & & Total CO2 Gene & ated & & $\cdot$ & \\
\hline & Total Test & Stage III & & (mM/130gWO) & & & & \\
\hline \multirow[t]{2}{*}{ Test } & Time & Ending Time & & & & & & \\
\hline & (min) & $(\min )$ & Slage I & Stape II & Stage III & Total & & $\dot{-}$ \\
\hline \multirow[t]{2}{*}{ T94-FPGlycolic-1 } & 330.00 & 290.00 & 138.22 & 21.33 & (a) & 159.56 & & \\
\hline & & & & & & & & \\
\hline T94-FPGlycolic-1a & 243.00 & 243.00 & 163.16 & 67.64 & 21.88 & 252.68 & & \\
\hline T94-FPOxalic-1 & 248.00 & 248.00 & (a) & (a) & 358.22 & 358.22 & & \\
\hline \multirow[t]{4}{*}{ T95-FPHNO3-3 } & 555.00 & 555.00 & na & na & na & 251.00 & & \\
\hline & & & & & & & & \\
\hline & & & & Tolal N2O Gen & ated & & & \\
\hline & Total Test & Stage III & & (mM/130gWO) & & & & \\
\hline \multirow[t]{2}{*}{ Test } & Time & Ending Tims & & & & & & \\
\hline & $(\min )$ & $(\min )$ & Stage I & Stage II & Stage III & Total & & \\
\hline & & & & & & & & 5 \\
\hline T94-FPGlycolic-1 & 330.00 & 290.00 & 0.12 & 1.42 & (a) & 2.18 & & \\
\hline \multirow[t]{2}{*}{ T94-FPGlycolic-1a } & 243.00 & 243.00 & 0.56 & 4.90 & 5.09 & 10.55 & & \\
\hline & & & & & & & & \\
\hline \multirow[t]{2}{*}{ T94-FPOxalic-1 } & 248.00 & 248.00 & (a) & (a) & 1.29 & 1.29 & & \\
\hline & & & & & & & & \\
\hline T95-FPHNO3-3 & 555.00 & 555.00 & na & na & na & 0.25 & & \\
\hline$\cdot$ & & & & & & & & \\
\hline a. no identifiable s & & & & & & & & \\
\hline
\end{tabular}


BVTD-C95-02.02K, Rev. 0

Page 43 of 45

Table 5.3.2 - Peak Offgas Generation Rates per 130gWO/, for the Altemate Flowsheet Meiter Feed Preparation Tests

\begin{tabular}{|c|c|c|c|c|c|c|c|}
\hline & & & $\mathrm{H2}$ & & & Co2 Stage! & Co2 Stage 1 \\
\hline & & & & & & & \\
\hline & & Time & & H2 Poak(c) & Time & & Peakcos \\
\hline Test & Description & (min) & & (mM/min) & $(\min )$ & & $(\mathrm{mM} / \mathrm{min})$ \\
\hline & & & & & & & \\
\hline TPLFPGlycolic-1 & glycolie reductant & 234 & & 0.0078 & 59 & & 8.7 \\
\hline . & Iinal titration & 310 & & 0.004 & (b) - & & (b) \\
\hline T94-FPGy colic-12 & re-itrate-3rd day & 150 & & 0.029 & 28 & & 12.7 \\
\hline & & & & & & & \\
\hline T94-FPOxalic-1 & loxalie reductan? & (b) & & 0 & 124 & & 6.6 \\
\hline & & & & & & & \\
\hline T95-FPHNO3-3 & nitric acid & 0 & & 0 & 43 & & 7 \\
\hline & & & & & & & \\
\hline 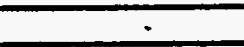 & & & CO2 Stage II & & & Co2 Slage III & Co2 Stage III \\
\hline & & & & & & & Prarm \\
\hline Test & Description - & $\frac{\text { Time }}{(\min )}$ & & $\frac{\text { Poak con }}{(\mathrm{mM} / \mathrm{min})}$ & $\frac{\text { Time }}{\text { (min) }}$ & & $\frac{\text { Poak coe }}{(\mathrm{mM} / \mathrm{min})}$ \\
\hline & & Lom & & 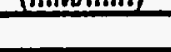 & & & 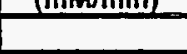 \\
\hline T94-FPGlycolic-1 & glycolic reductant & (b) & & (b) & no stage & & \\
\hline & final titration & 320 & & 0.94 & & & \\
\hline & & & & & & & \\
\hline TS4-FPGlycolic-1a & re-titrate 3rd day & (b) & & (b) & 150 & & -0.5 \\
\hline & & & & & & & \\
\hline T94-FPOxalic-1 & oxalie reductant & Slage $1 \& \| 1 \mathrm{~m}$ & god and no Stac & III & & - & \\
\hline & & & & & & & \\
\hline T95-FPHNO3-3 & Initric acid & Stage | \& II I & ged & & 129 & & 1 \\
\hline & & & $N O x$ & & & $\mathrm{~N} 20$ & NEO \\
\hline & & & & & & & nolim \\
\hline Test & Description & Time & & PoakNOx & Time. & & Peak NeO \\
\hline & & $(\min )$ & & $(\mathrm{mM} / \mathrm{min})$ & (min) & & $(\mathrm{mM} / \mathrm{min})$ \\
\hline TQ4-FPGlycolic-1 & glycolic roductant & 66 & & 0.408 & 280 & & 0.017 \\
\hline & final titration & 305 & & 1.59 & 323 & & 0.12 \\
\hline & & & & & & & $\dot{-}$ \\
\hline T94-FPGlycolic-1a & re-titrale 3rd day & 50 & & 3.16 & 61 & & 0.16 \\
\hline & & & & & & & \\
\hline TS4-FPOxalic-1 & oxalic reductant & 95 & & 2.67 & 212 & & 0.024 \\
\hline & L & & & & & & \\
\hline T95.FPHNO3.3 & Initric acid & 47 & & 2.51 & na & & na \\
\hline
\end{tabular}


nitrate). The resulting feeds were evaluated for theological properties using a Haaka (model $x 00 x x$ ) Rheometer. (An acceptable feed will display a viscosity which is less than $25 \mathrm{pa} \cdot \mathrm{s}$ and a shear strength which is less than $15 \mathrm{pa}$ while having a total oxide loading of greater than $400 \mathrm{~g} / \mathrm{L}$.)

The theological evaluation showed that the glycolic acid treated feed had acceptable theological properties at a total oxide loading of 400 while the nitric acid feed could not be more concentrated than 380 and display acceptable theology and oxalic acid treated feed could only be concentrated to 280. Hence, oxalic acid was eliminated from further testing and a nitric acid processed and a glycolic acid processed feed were recommended for the SSHTM melter tests. 


\subsection{References}

Beckette, M. R. and L. K. Jagoda (1994). Detailed Design Data Package; NCAW Waste Simulant Properties (SIPT 2/LFCM 8 Campaign), PHTD-K1017, Rev. 0, U. S. Department Energy Report, Pacific Northwest Laboratory, Richland, Washington.

Pattello, G.K., H.D. Smith, K.D. Wiemers, R.D. Bell, R.E.Williford and R.G. Clemmer. 1994. Evaluation of HWVP Feed Preparation Chemistry for an NCAW Simulant-Fiscal Year 1993: Effect of Noble Metals Concentration on Offgas Generation and Ammonia Formation. PVTD-TDE-94439, Technical Report to Westinghouse Hanford Company, Pacific Northwest Laboratory, Richland, Washington.

Ritter, J. A., J. R. Zamecnik, and C. W. Hsu. 1992. "Hydrogen Generation During Treatment of Simulated High-Level Radioactive Waste with Formic Acid(U)." In Proceedings of the Third Intermational Conference on High Level Radioactive Waste Management. Las Vegas, Nevada, April 12-16, 1992.

Sills, J.A. 1995. "Evaluation of Hanford High Level Waste Vitrification Chemistry for an NCAW" Simulant - FY 1994: Potential Exothermic Reactions in the Presence of Formic Acid, Glycolic Acid, and Oxalic Acid." PNL Technical Document Number PNL-10564. Pacific Northwest Laboratory, Richland, Washington.

Smith, H.D., K.D. Wiemers, M.H. Langowski, M.R. Powell, and D.E. Larson. 1995. HWVP Feed Preparation Chemistry for an NCAW Simulant, Fiscal Year 1992: Evaluation of Offgas Generation and Ammonia Formation, PHTD-10369, UC-721, Pacific Northwest Laboratory, Richland, WA.

Wiemers, K. D., M. H. Langowski, M. R. Powell, and D. E. Larson. 1993. Evaluation of HWVP Feed Preparation Chemistry for an NCAW Simulant-Fiscal Year 1991: Evaluation of Offgas Generation, Reductant Requirements and Thermal Stability. Technical Report PHTD-93-K899, Rev. 0, Pacific Northwest Laboratory, Richland, Washington. 


\section{Appendix}

This appendix contains summary documents which bring together the data that pertains to the tests discussed in the text but was not presented specifically there. They include:

- The objective and outline for each test

- A set of summary time lines for each test including key events and observations.

- A transcribed activity log for each tests giving more detail.

- A set of tables giving a summary of the analytical result for samples taken from each test. 


\section{Test Objectives and Outline for Test-T94-HCOOHBase-1}

\section{Objectives}

The objective of this test is to establish a baseline set of values for off-gas and slurry chemistry in terms of rates and amounts. Utilizing SIPT 94 version of NCAW nominal slurry simulant. Nitrite and nitrate were shimmed to $30 \%$ and $300 \%$ of the nominal values to develop worst case conditions in the simulant for $\mathrm{H}_{2}$ and $\mathrm{NH}_{3}$ generation.

\section{Test Outline}

1. Weigh out required amount of slurry ( $1540 \mathrm{~g}$ NCAW slurry) and Noble metals slurry (57.8g ) add required amount of shim chemicals.

II. Place slurry in. reaction vessel. Begin agitation and heating of slurry. Slart offgas system.

III. Boil for approximately 15 minutes. Replace condensate with deionized water. Collect condensate and slurry sample for chemical analysis.

IV. Cool slurry to $95^{\circ} \mathrm{C}$. Prepare to add $\mathrm{HCOOH}$ acid at $0.67 \mathrm{~g} / \mathrm{min}$. (90.6wt. \%), measure $\mathrm{pH}$.

V. Add $122.0 \mathrm{~g} \mathrm{HCOOH}$ acid solution during test.

VI. Collect condensate during $\mathrm{HCOOH}$ acid addition. Take $\mathrm{HCOOH}$ acid addition slumy sample at completion of $\mathrm{HCOOH}$ addition.

VII. Digest slurry at boiling for 4 hours. Remove condensate and replace with deionized water.

VIII. Take post digestion slurry sample for physical property and chemical analysis. 
Test Objeçtlves and Outline for Test-T94-HCOOHBase-2

\section{Objectives}

The objective. of this test is to rerun T94-HCOOHBase-1 for reproducibility. Once the test has run a sufficient time to establish reproducibility the effect of $\mathrm{NaNO}_{2}$ addition on $\mathrm{H}_{2}$ generation will be observed.

\section{Test Outline}

1. Weigh out required amount of slurry (1540g NCAW slurry) and Noble metals slurry $(57.8 \mathrm{~g})$ add required amount of shim chemicals.

11. Place slurry in reaction vessel. Begin agitation and heating of slurry. Start offgas system.

iil. Boil for approximately 15 minutes. Replace condensate with deionized water. Collect condensate and slurry sample for chemical analysis.

IV. Cool slurry to $95^{\circ} \mathrm{C}$. Prepare to add $\mathrm{HCOOH}$ acid at $0.67 \mathrm{~g} / \mathrm{min}$. (90.6wt. \%), measure $\mathrm{pH}$.

V. Add 122.0g HCOOH acid solution during test.

V. Collect coridensate during $\mathrm{HCOOH}$ acid addition. Take $\mathrm{HCOOH}$ acid addition slurry sample at completion of $\mathrm{HCOOH}$ addition.

VII. Digest slurry at boiling. Remove condensate and replace with deionized water to maintain $<140 \mathrm{gWO} / \mathrm{L}$ Hold at boiling for 1.5 hours. Add $5.0 \mathrm{~g} \mathrm{NaNO2}$ in $10.0 \mathrm{~g}$ deionized water. Hold at boiling conditions for 2.5 hours. Collect condensate.

VIII. Take post digestion slurry sample for physical property and chemical analysis. 


\section{Test Objectives and Outline for Test-T94-CITRIC-1}

\section{Objectives}

The objective of this test is to compare the titration of NCAW waste simulant with Citric acid and a similar titration with $\mathrm{HCOOH}$. Citric acid will be added and conditions generated under which $\mathrm{H}_{2}$ and $\mathrm{NH}_{3}$ would be generated if $\mathrm{HCOOH}$ were used.

\section{Test Outline}

1. Weigh out required amount of slurry (1540g NCAW slurry) and Noble metals slurry. $(57.8 \mathrm{~g})$ add required amount of shim chemicals.

II. Place slurry in reaction vessel. Begin agitation and heating of slurry. Start offgas system.

III. Boil until $80.0 \mathrm{~g}$ condensate removed. Replace condensate with deionized water. Collect condensate and slurry sample for chemical analysis.

IV. Cool slurry to $950 \mathrm{C}$. Prepare to add Citric acid at $2.33 \mathrm{~g} / \mathrm{min}$. (55.6wt. \%), measure $\mathrm{pH}$. Start addition at half rate until acid is entering vessel.

V. Add $414.0 \mathrm{~g}$ Citric acid solution during test.

VI. Collect condensate during Citric acid addition. Take Citric acid addition slumy sample at completion of Citric addition.

VII. Digest slurry at boiling for four hours. Remove condensate and replace with deionized water to maintain $<140 \mathrm{gWO} / \mathrm{L}$.

VIII. Take post digestion slurry sample for physical property and chemical analysis. 
Test Objectives and Outline for Test-T94-GLYCOLIC-1

\section{Objectives}

The objective of this test is to compare the titration of NCAW waste simulant with Glycolic acid and a similar titration with $\mathrm{HCOOH}$. Glycolic acid will be added and conditions generated under which $\mathrm{H}_{2}$ and $\mathrm{NH}_{3}$ would be generated if $\mathrm{HCOOH}$ were used.

\section{Test Outline}

1. Weigh out required amount of slurry (1540g NCAW slurry) and Noble metals slurry $(57.8 \mathrm{~g})$ add required amount of shim chemicals.

II. Place slurry in reaction vessel. Begin agitation and heating of slurry. Start offgas system.

III. Boil until $131.6 \mathrm{~g}$ condensate removed. Replace condensate with deionized water. Collect condensate and slurry sample for chemical analysis.

IV. Cool slurry to $95^{\circ} \mathrm{C}$. Prepare to add Glycolic acid at $1.46 \mathrm{~g} / \mathrm{min}$. $(70.6 \mathrm{wt}$. \%), measure $\mathrm{pH}$. Start addition at half rate until acid is entering vessel.

V. Add 259g Glycolic acid solution during test.

VI. Collect condensate during Glycolic acid addition. Take Glycolic acid addition slurry sample at completion of Glycolic addition.

VII. Digest slurry at boiling for four hours. Remove condensate and replace with deionized water to maintain <140gWO/L.

VIII. Take post digestion slurry sample for physical property and chemical analysis. 
Test Objectives and Outline for Test-T94-FPGLYC-1

\section{Objectives}

The objective of this test is to produce simulated melter feed for both the HTM and SM using a minimum amount of organic acid to produce good feed meology.

\section{Test Outllne}

1. Weigh out required amount of slurry (1870g NCAW slurry) and Noble metals slurry $(38.5 \mathrm{~g})$ add required amount of shim chemicals.

II. Place slurry in reaction vessel. Begin agitation and heating of slurry. Start offgas system.

III. Boil for15 minutes. Reflux condensate and collect slurry sample for chemical analysis.

IV. Cool slurry to $95^{\circ} \mathrm{C}$. Prepare to add Glycolic acid at $1.7 \mathrm{~g} / \mathrm{min}$. (70.6wt. \%), measure pH. Start addition at half rate until acid is entering vessel.

V. Add $99.7 \mathrm{~g}$ Glycolic acid solution during test.

VI. Collect $354 \mathrm{~g}$ condensate during Glycolic acid addition or the equivalent to180gWO/L. Take Glycolic acid addition slurry sample at completion of Glycolic addition.

VII. Cool slurry to $95^{\circ} \mathrm{C}$. Prepare to add $29 \mathrm{~g}$ Glycolic acid at $1.7 \mathrm{~g} / \mathrm{min}$. $(70.6 \mathrm{wt}$. \%), until $\mathrm{pH}$ reaches $\sim 5.5$. Start addition at half rate until acid is entering vessel. 


\section{Test Objectives and Outline for Test-T94-LACTIC-1}

\section{Objectives}

The objective of this test is to add Lactic acid under the same conditions as HCOOH in Test T94-HCOOHBase-1 and compare the offgas composition. Lactic and HCOOH have the same acid equivalent per mole. The Lactic acid will be added at the same rate of $\mathrm{HCOOH}$ and conditions generated under which $\mathrm{H}_{2}$ and $\mathrm{NH}_{3}$ would be generated if $\mathrm{HCOOH}$ were used.

If the gas evolution becomes to intense the addition rate will be reduced.

\section{Test Outline}

1. Weigh out required amount of slurry (1540g NCAW slurry) and Noble metals slurry $(57.8 \mathrm{~g})$ add required amount of shim chemicals.

I1. Place slurry in reaction vessel. Begin agitation and heating of slurry. Start offgas system.

III. Boil for approximately 15 minutes. Replace condensate with deionized water. Collect condensate and slurry sample for chemical analysis.

IN. Cool slurry to $95^{\circ} \mathrm{C}$. Prepare to add Lactic acid at $1.4 \mathrm{~g} / \mathrm{min}$. (85.0wt. \%), measure $\mathrm{pH}$.

V. Add $257.6 \mathrm{~g}$ Lactic acid solution during test.

VI. Collect condensate during Lactic acid addition. Take lactic acid addition slurry sample at completion of lactic addition.

VII. Digest slurry at boiling for four hours. Remove condensate and replace with deionized water to maintain $<140 \mathrm{gWO} / \mathrm{L}$.

VIII. Take post digestion slurry sample for physical property and chemical analysis. 


\section{Test. Objectlves and Outline for Test-T94-HNO -1}

\section{Objectives}

The objetive of this test is to utilize an NCAW simulant processed with $\mathrm{HNO}_{3}$ in the same manner as $\mathrm{HCOOH}$. First, to determine gases generated upon $\mathrm{HNO}_{3}$ addition. Second, to establish $\mathrm{H}_{2}$ and $\mathrm{NH}_{3}$ are/are not generated when $\mathrm{NHO}_{3}$ is used for processing slurry.

\section{Test Outline}

1. Weigh out required amount of slurry $(1665 \mathrm{~g})$ add Noble metals slurry $(29.7 \mathrm{~g})$ and required amount of shim chemicals.

II. Place slurry in reaction vessel. Begin agitation and heating. Start off-gas system.

III. Boil approximately 15 minutes. Replace condensate with deionized water. Collect condensate and slurry sample for chemical analysis.

IV. Cool slurry to $950 \mathrm{C}$. Prepare to add $\mathrm{HNO}_{3}$ at $1.22 \mathrm{~g} / \mathrm{min}$. $(70.0 \mathrm{wt}$. \%), measure $\mathrm{pH}$.

V. Add $130.4 \mathrm{~g} \mathrm{HNO}_{3}$ solution during test.

VI. Collect condensate during $\mathrm{HNO}_{3}$ addition. Take $\mathrm{HNO}_{3}$ addition slurry sample at completion of $\mathrm{HNO}_{3}$ addition.

VII. Digest slurry at boiling conditions for four hours. Collect condensate.

VIII. Take post digestion slurry sample for physical property and chemical analysis. 


\section{Test Objectives and Outline for Test-T94-OXAL 1}

\section{Objectives}

The objetive of this test is to utilize an NCAW simulant processed with Oxalic acid to determine what compounds are formed. The formation of dissolved compounds in slurry and offgas will be observed. Oxalic acid will be added until all nitrite is destroyed and conditions are generated under which $\mathrm{H}_{2}$ and $\mathrm{NH}_{3}$ would be generated if $\mathrm{HCOOH}$ were used.

\section{Test Outline}

I. Weigh out required amount of slurry (1920g dilute SIPT slurry) and add required amount of shim chemicals.

II. Place slurry in reaction vessel. Begin agitation and heating. Start offgas system.

III. Boil until $199.4 \mathrm{~g}$ of condensate has been removed. Collect condensate and slurry sample for chemical analysis.

IV. Cool slurry to $950 \mathrm{C}$. Prepare to add Oxalic acid at $2.2 \mathrm{~g} / \mathrm{min}$. (28.6Wt. \%), measure $\mathrm{pH}$.

V. Add $460.0 \mathrm{~g}$ Oxalic solution during test.

VI. Collect condensate during Oxalic acid addition. Take Oxalic acid addition slurry sample at completion of Oxalic addition.

VII. Digest slurry at boiling until nitrogen oxides generation ceases then continue for an hour. Collect condensate.

VIII. Take post digestion slurry sample for physical property and chemical analysis. 


\section{Test Objectives and Outline for Test-T94-FPOXAL}

\section{Objectives}

The objective of this test is to produce an HTM melter feed from an NCAW slurry simulant processed with Oxalic acid. An evaluation of chemistry changes via offgas measurements and chemical analysis of slurry and melter feed samples will be made.

\section{Test Outline}

1. Weigh out required amount of slurry (1980g concentrated SIPT slurry) and Noble metals stumy (39.6g) add required amount of shim chemicals. Add $83.1 \mathrm{~g}$ of $\mathrm{NaHCO}_{3}$.

II. Place slurry in reaction vessel. Begin agitation and heating of slurry. Start offgas system.

III. Boil until $189.0 \mathrm{~g}$ condensate removed. Collect condensate and slurry sample for chemical analysis.

IV. Cool slurry to $950 \mathrm{C}$. Prepare to add Oxalic acid at $2.2 \mathrm{~g} / \mathrm{min}$. (28.5wt. \%), measure pH.

V. Add $423.4 \mathrm{~g}$ Oxalic acid solution during test.

VI. Collect condensate during Oxalic acid addition. Take Oxalic acid addition slurny sample at completion of Oxalic addition.

VII. Digest slurry at boiling until $107.8 \mathrm{~g}$ condensate removed.

VIII. Take post digestion slurry sample for physical property and chemical analysis. 


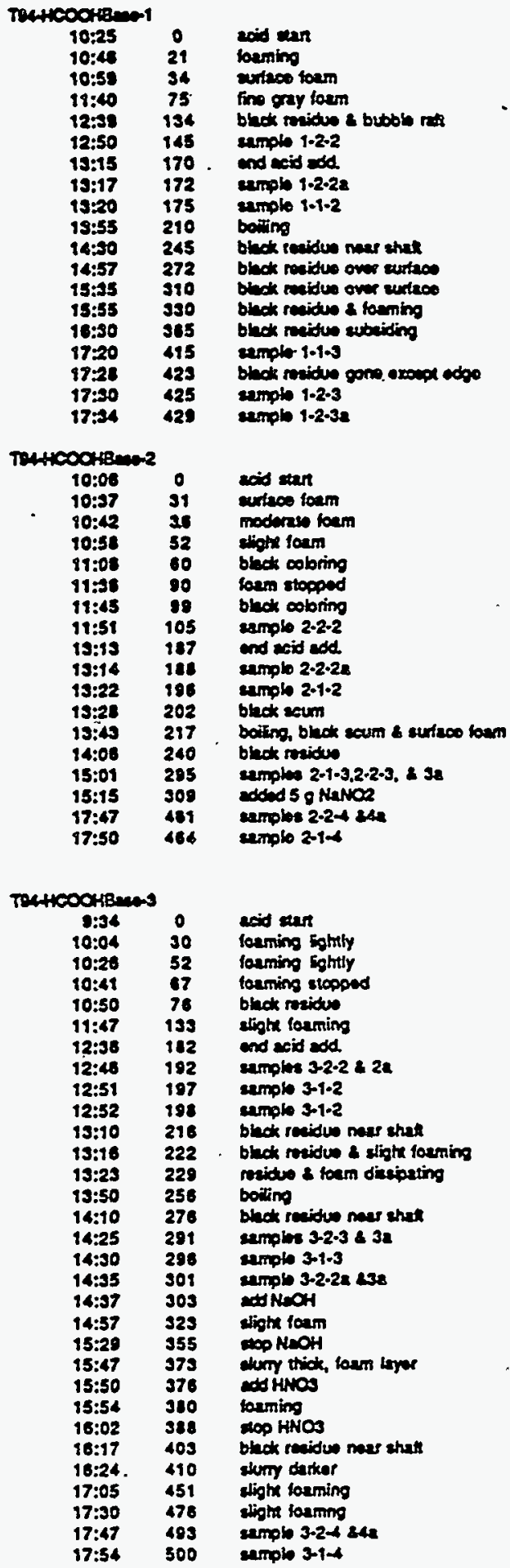




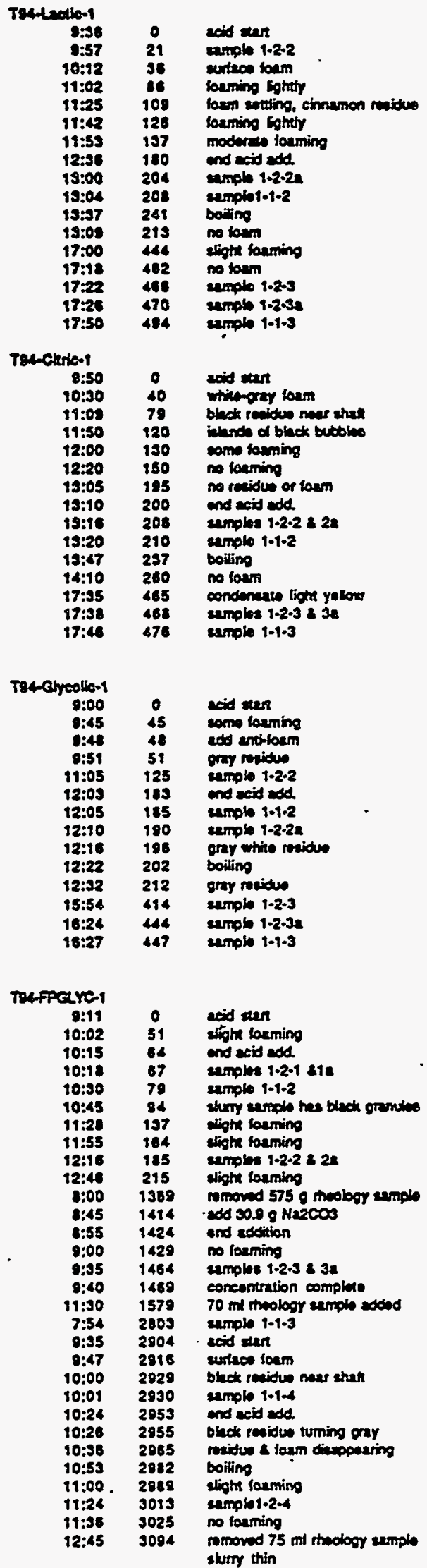




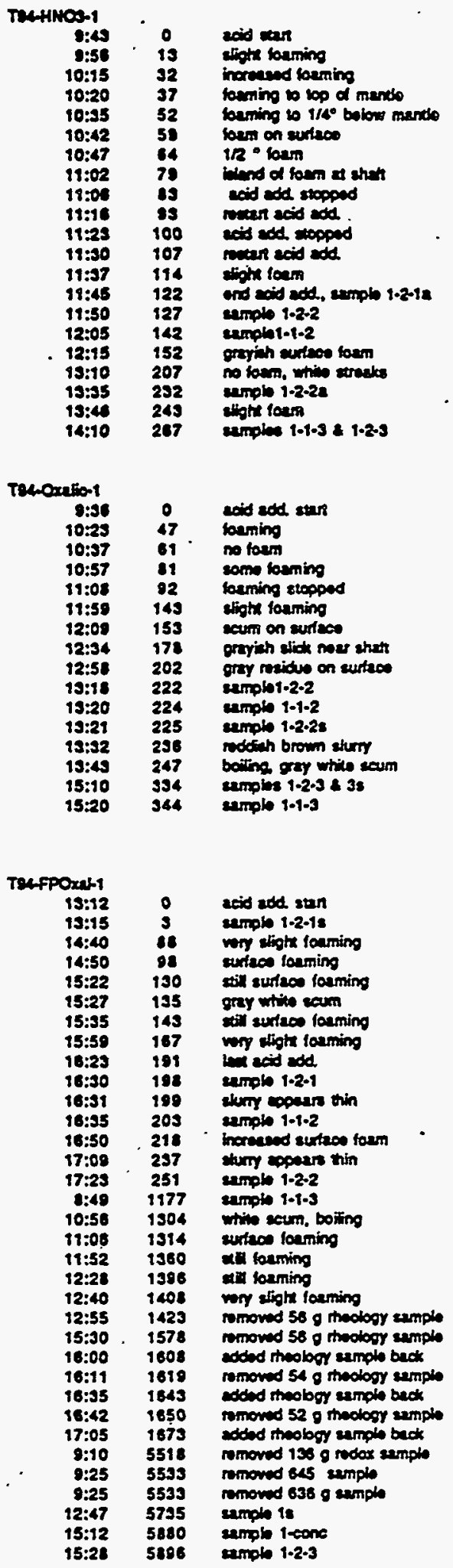




\section{Laboratory Melter Eeed Preparation Activity Log}

The "Laboratory Melter Feed Preparation Activity Log" is a transcription of the actual log kept during the test nun. Though it does not contain all of the entries (redundant entries were eliminated) it contains all of the information of the original log. Its main purpose is to provide a record of observations made during the test that were not being recorded by other means and that would correlate with other data such as the off-gas data: The basis for correlation with other data is "24 hour" military time. The observations recorded relate principally to the slurry condition: color, foaming, other phases present but also includes a record of condenser temperatures (laboratory tests) and other activities carried out during the test run along with comments about the operation of the apparatus itself.

The DaterTime column gives the day the run activity was occurring and the "24 hour" time that the data was recorded or an activity commenced. Zero time is defined as the start of acid addition and the final $\log$ entry is entered at the time off-gas data collection stopped. The $\mathrm{pH}$ was a manually recorded value from the pH probe (temperature compensated for laboratory tests but not for the small-scale system). The Activity/Observations column attempts to succinctly express relevant activities or actions at the time indicated in the first column. Activities may include:

-Heating or cooling the slurry.

-Observations about the slurry such as slurry color or degree of foaming.

-Condensate or slurry sample collection.

-Unusual off-gas activity.

-Start of acid addition and the rate of addition.

Laboratory-scale tests Activity Logs T94-HCOOHBase-1, T94-HCOOHBase-2, T94-HCOOHBase3, T94-Citric-1, T94-Glycolic-1, T94-Lactic-1, T94-HNO3-1, T94-Oxalic-1 and laboratory Melter Feed Preparation Activity Logs T94-FPGLYC-1, T94-FPOXAL-1, and T95-FPHNO3-3, follow respectively. 


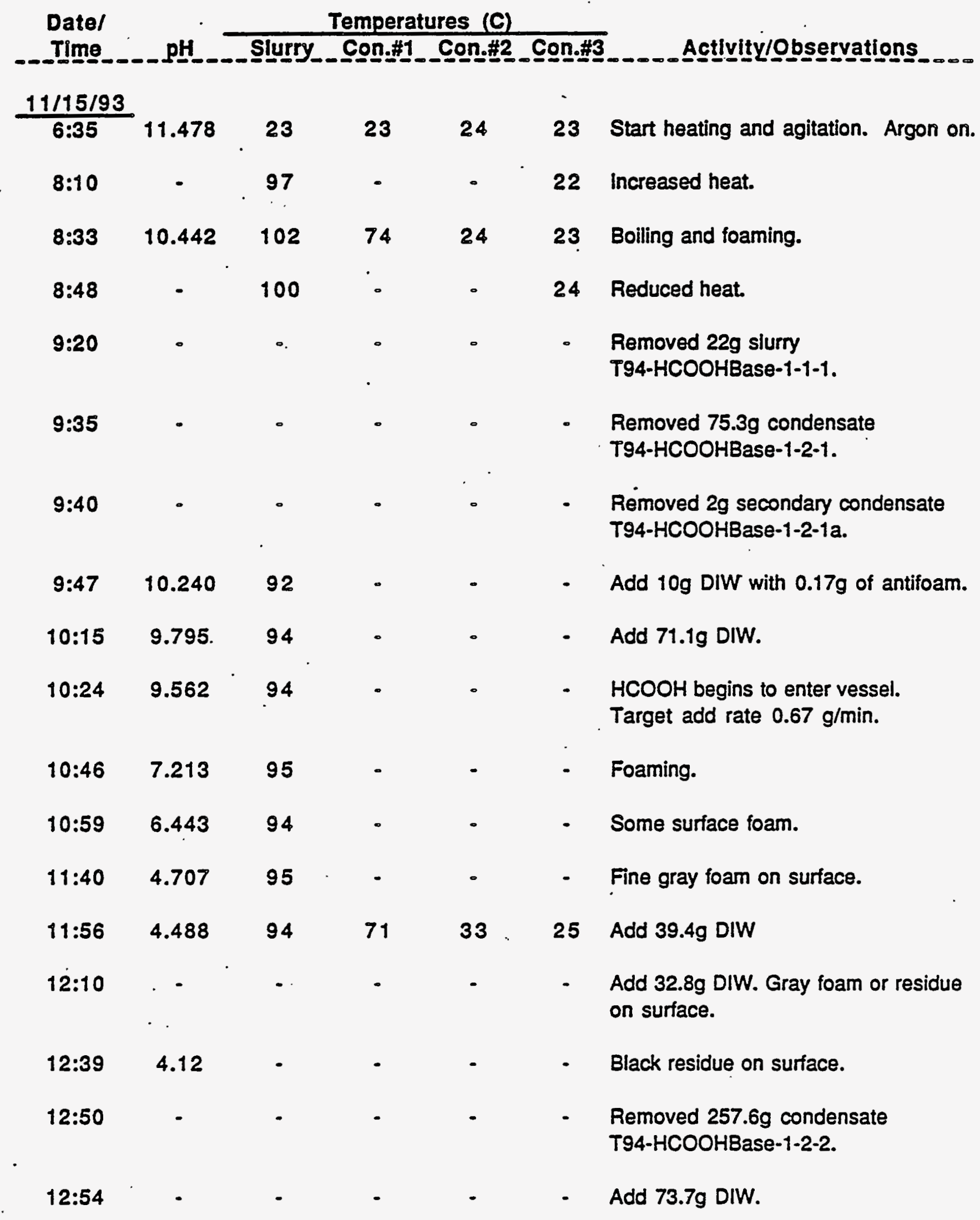




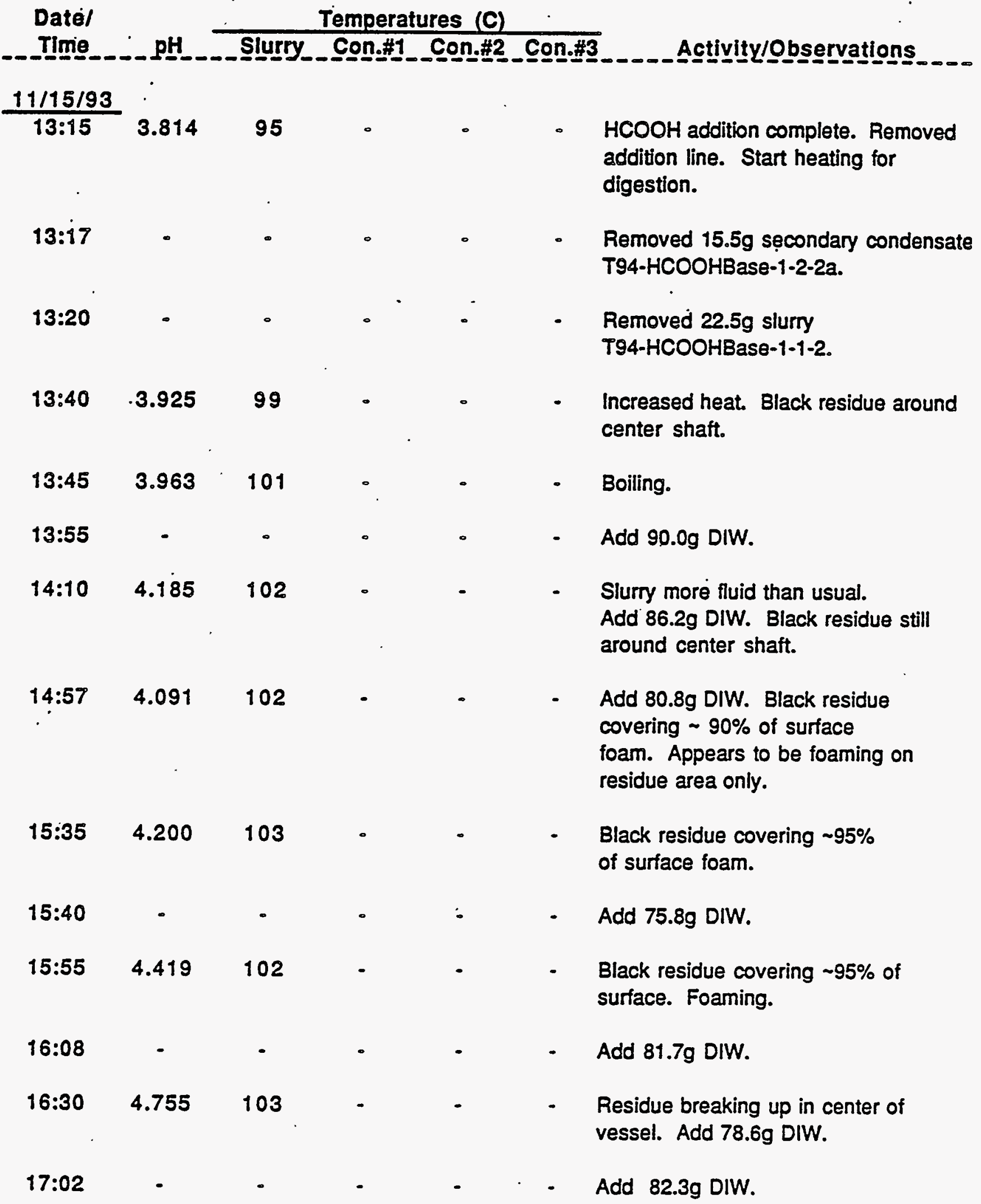




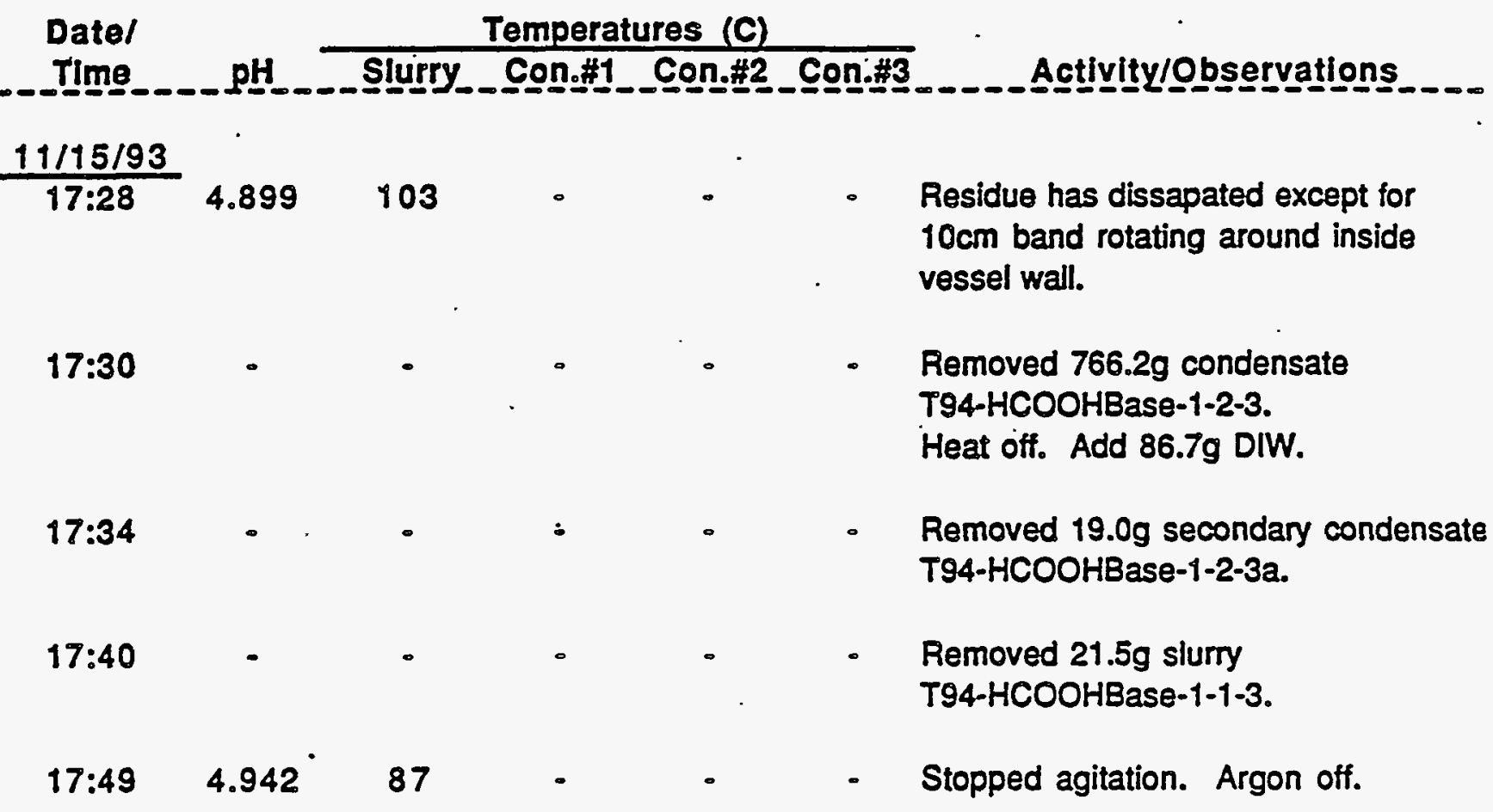




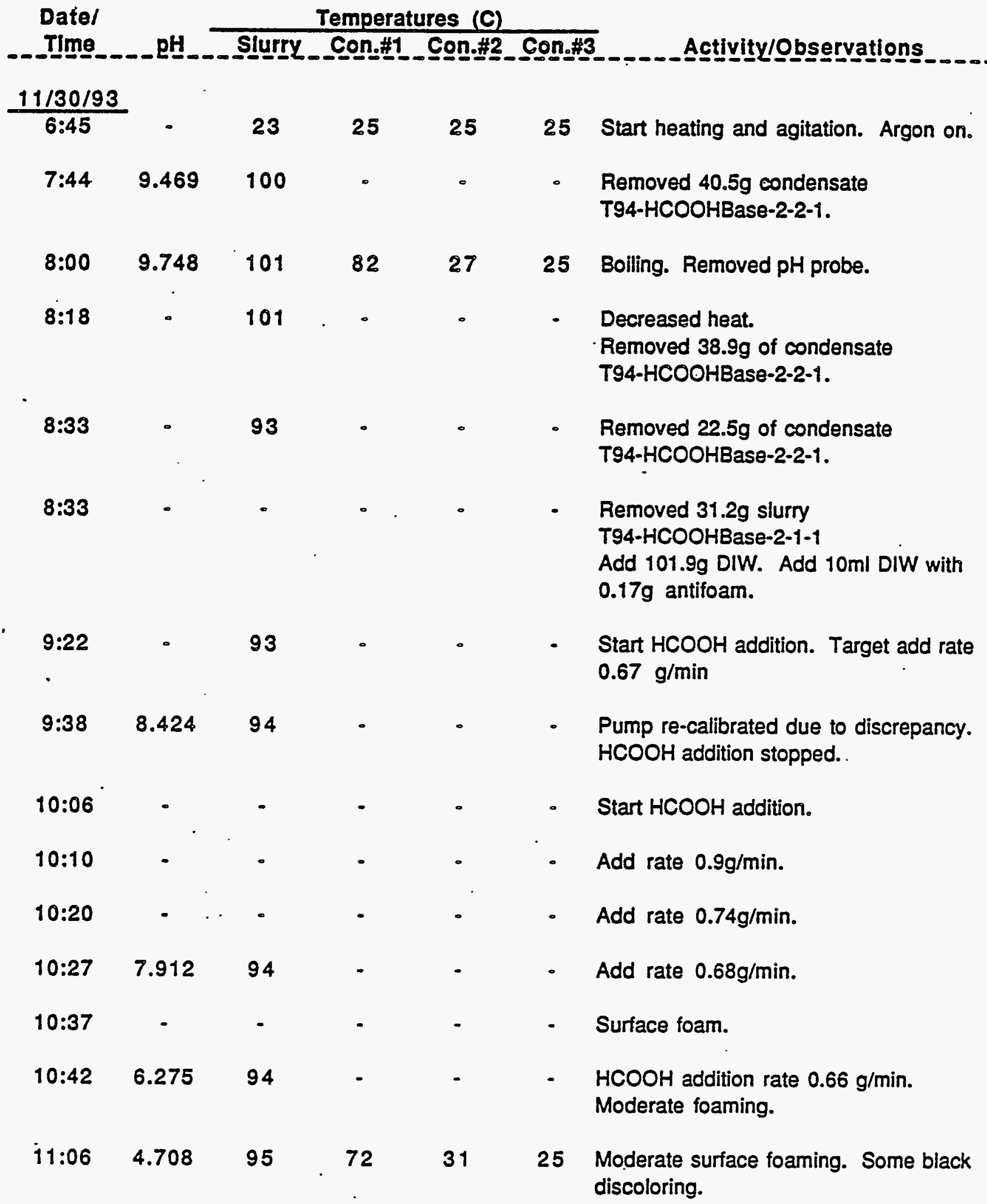




\begin{tabular}{|c|c|c|c|c|c|c|}
\hline \multicolumn{2}{|c|}{ Datel } & \multicolumn{4}{|c|}{ Temperatures (C) } & Activity/Observations \\
\hline $11 / 30 / 93$ & & & & & & \\
\hline $11: 45$ & 3.461 & 95 & 74 & 31 & 24 & $\begin{array}{l}\text { Surface foam stopped. Some black } \\
\text { discoloring around center stir shaft. }\end{array}$ \\
\hline $12: 38$ & 2.942 & 95 & 75 & 32 & 25 & - \\
\hline $13: 13$ & - & - & - & 。 & - & Stopped $\mathrm{HCOOH}$ addition. \\
\hline 13:22 & 2.684 & 95 & - & - & - & $\begin{array}{l}\text { Removed } 16.1 \mathrm{~g} \text { slurry } \\
\text { T94-HCOOHBase-2-1-2. } \\
\text { Start heating. }\end{array}$ \\
\hline $13: 28$ & 2.756 & 95 & - & . & - & $\begin{array}{l}\text { Some black surface foam around centep } \\
\text { stir shaft. }\end{array}$ \\
\hline $13: 32$ & 2.835 & 101 & - & - & - & $\begin{array}{l}\text { Smail amount of black foam on surface } \\
\text { foam. }\end{array}$ \\
\hline $13: 43$ & 2.998 & 101 & - & - & - & Boiling. \\
\hline $13: 49$ & 3.074 & 101 & - & - & - & Add 116.3g DIW. \\
\hline $14: 06$ & 3.221 & 101 & - & - & - & $\begin{array}{l}\text { Some black residue mixed with surface } \\
\text { foam. }\end{array}$ \\
\hline $14: 25$ & - & - & - & - & - & Add $78.2 \mathrm{~g}$ DIW. \\
\hline 15:01 & - & - & 。 & - & - & $\begin{array}{l}\text { Removed } 13.6 \mathrm{~g} \text { slurry } \\
\text { T94-HCOOHBase-2-1-3. } \\
\text { Add } 76.7 \mathrm{~g} \text { DIW. }\end{array}$ \\
\hline
\end{tabular}




\begin{tabular}{|c|c|c|c|c|c|c|}
\hline \multirow{3}{*}{$\begin{array}{l}\text { Datel } \\
\text { Tlme } \\
12 / 6 / 93\end{array}$} & \multirow{2}{*}{$\mathrm{pH}$} & \multicolumn{4}{|c|}{ - Temperatures (C) } & \multirow{2}{*}{ Activity/OQbservations } \\
\hline & & Slurry & Con.t. & Con: & Con.\#3 & \\
\hline & & & & & & \\
\hline $6: 30$ & 10.72 & 23 & 23 & 23 & - & Start heating and agitation. Argon on. \\
\hline $7: 28$ & - & 101 & - & : & . & Boiling. \\
\hline $7: 30$ & - & - & - & . & - & $\begin{array}{l}\text { Took first initial condensate } \\
\text { T94-HCOOHBase-3-2-1. }\end{array}$ \\
\hline $7: 45$ & 10.39 & 101 & $\therefore$ & - & - & Reduced heating power. \\
\hline $7: 49$ & - & - & - & - & - & Add 67.2g DIW. \\
\hline $8: 05$ & - & 93 & 71 & 26 & 25 & - \\
\hline $8: 20$ & - & 。 & - & . & . & $\begin{array}{l}\text { Removed } 14.0 \mathrm{~g} \text { slurry } \\
\text { T94-HCOOHBase-3-1-1. }\end{array}$ \\
\hline $8: 23$ & - & - & - & . & - & Add $10 \mathrm{ml}$ DIW with $0.17 \mathrm{~g}$ of antifoam. \\
\hline 9:23 & - & - & - & - & - & $\begin{array}{l}\mathrm{HCOOH} \text { addition begins. Target } \\
\text { addition rate } 0.67 \mathrm{~g} / \mathrm{min} \text {. }\end{array}$ \\
\hline $10: 04$ & $\cdot$ & - & - & - & - & $\begin{array}{l}\text { Slight foaming. } \\
\text { Add rate } 0.67 \mathrm{~g} / \mathrm{min} \text {. }\end{array}$ \\
\hline $10: 15$ & 6.58 & 94 & - & - & - & Still slight foaming. \\
\hline $10: 26$ & 5.84 & 95 & - & - & - & Still slight foaming. \\
\hline $10: 41$ & 5.26 & 95 & - & - & - & Foaming stopped. \\
\hline $10: 50$ & 4.61 & 95 & - & - & - & $\begin{array}{l}\text { Small amount of black residue on } \\
\text { surface. }\end{array}$ \\
\hline $11: 07$ & 4.23 & 95 & - & - & - & Add rate $0.60 \mathrm{~g} / \mathrm{min}$. \\
\hline $11: 28$ & 4.16 & 95 & 75 & 32 & 25 & Slight foaming and surface mist. \\
\hline $11: 52$ & 3.82 & 95 & 74 & 33 & 25 & - \\
\hline
\end{tabular}




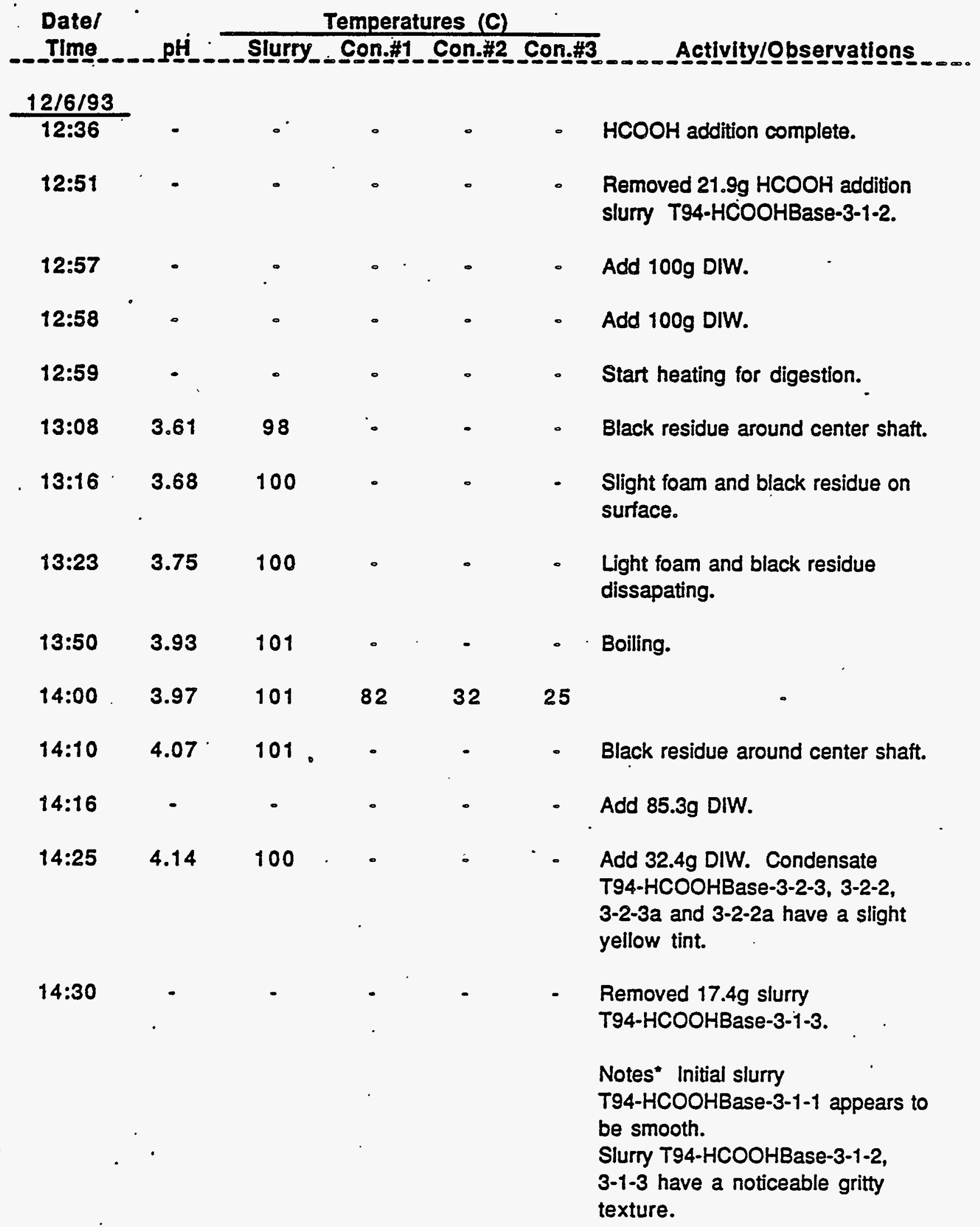


Date/

Temperatures (C)

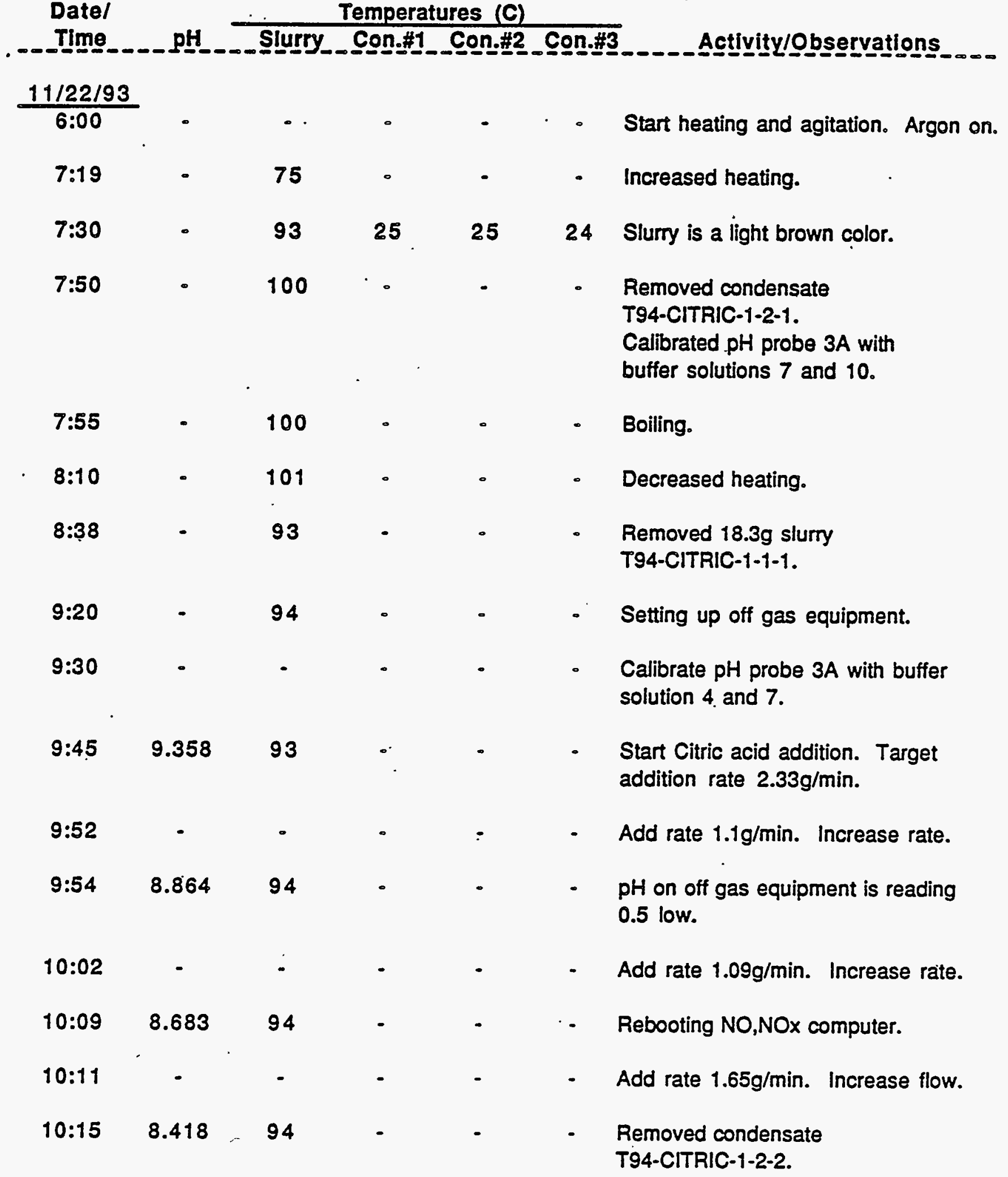




\begin{tabular}{|c|c|c|c|c|c|c|}
\hline \multirow{2}{*}{ Datel } & \multicolumn{5}{|c|}{ Temperatures (C) } & \multirow{2}{*}{ Activity/Observations } \\
\hline & pH & Slurry & II:- & Onn. & Son.\#3. & \\
\hline $11 / 22 / 93$ & & & & & - & \\
\hline $10: 19$ & 8.093 & 94 & - & $\therefore$ & - & Add rate $1.57 \mathrm{~g} / \mathrm{min}$. Increase flow. \\
\hline $10: 30$ & - & - & - & - & - & Grayish white foam on surface. \\
\hline 10:32 & 7.277 & 94 & - & - & $\therefore$ & Increase pump setting. \\
\hline $10: 39$ & 6.944 & 94. & - & - & - & Add rate $2 \mathrm{~g} / \mathrm{min}$. Increase flow. \\
\hline $10: 47$ & - & - & $:$ & - & - & Add rate $2.02 \mathrm{~g} / \mathrm{min}$. Increased flow. \\
\hline $10: 57$ & - & - & - & - & 。 & Increased pump setting. \\
\hline $10: 59$ & 5.918 & 94 & 27 & 32 & 24 & - \\
\hline $11: 08$ & 5.594 & 95 & - & - & - & Add rate $2.13 \mathrm{~g} / \mathrm{min}$. Increased flow. \\
\hline $11: 09$ & - & - & - & - & - & Black residue around center shaft. \\
\hline $11: 11$ & - & - & - & - & - & Add rate $2.25 \mathrm{~g} / \mathrm{min}$. Increase flow. \\
\hline $11: 19$ & 5.116 & 94 & - & - & - & Add rate $2.4 \mathrm{~g} / \mathrm{min}$. Decrease flow. \\
\hline $11: 23$ & - & - & - & - & - & Add rate $2.4 \mathrm{~g} / \mathrm{min}$. Decrease flow. \\
\hline $11: 26$ & 4.98 & 95 & - & - & - & Add rate $2.3 \mathrm{~g} / \mathrm{min}$. \\
\hline $11: 50$ & 4.421 & 95 & - & - & $\cdot$ & $\begin{array}{l}\text { Island of black bubbles floating on } \\
\text { surface. }\end{array}$ \\
\hline $12: 00$ & 4.067 & 95 & 27 & 32 & 25 & Slight foam on surface. \\
\hline $12: 20$ & 3.514 & 95 & 28 & 32 & 25 & Foam is gone. \\
\hline $12: 40$ & 3.054 & 95 & - & - & $\cdot$ & - \\
\hline 13:05 & 2.582 & 95 & - & - & & $\begin{array}{l}\text { No floating residue or foam. } \\
\text { Citric acid addition complete. }\end{array}$ \\
\hline $13: 20$ & - & - & - & - & & $\begin{array}{l}\text { Removed } 17.6 \mathrm{~g} \text { slurry } \\
\text { T94-CITRIC-1-1-2. }\end{array}$ \\
\hline
\end{tabular}




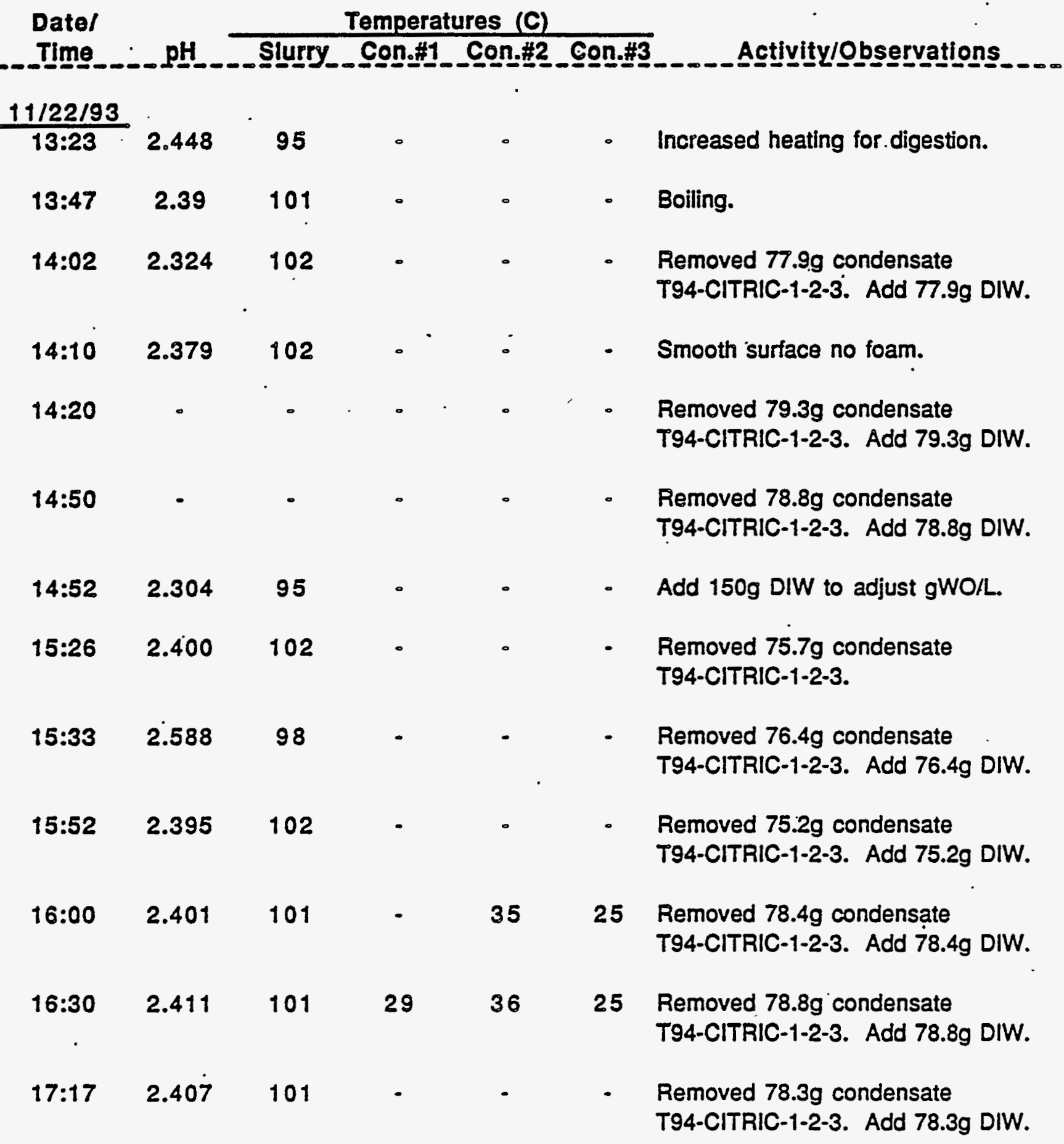




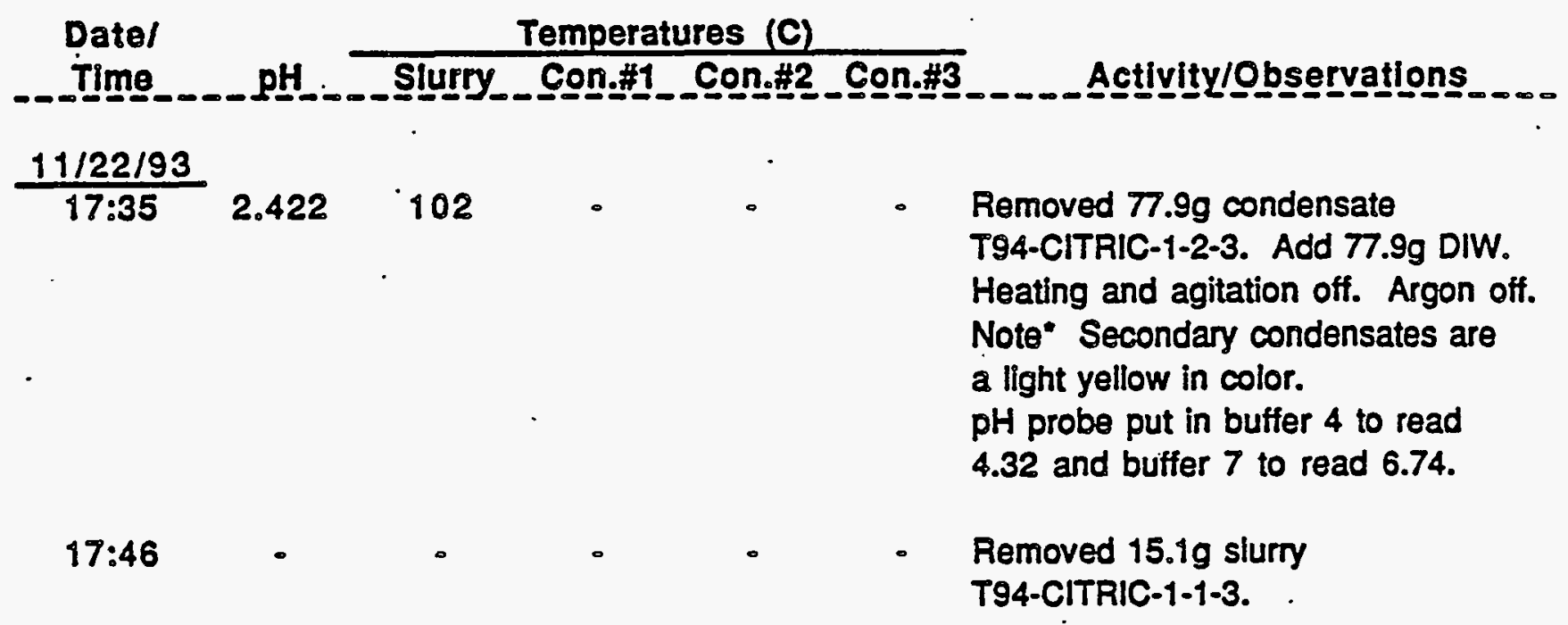


Activity Log - Test T94-GLYCOLIC-1

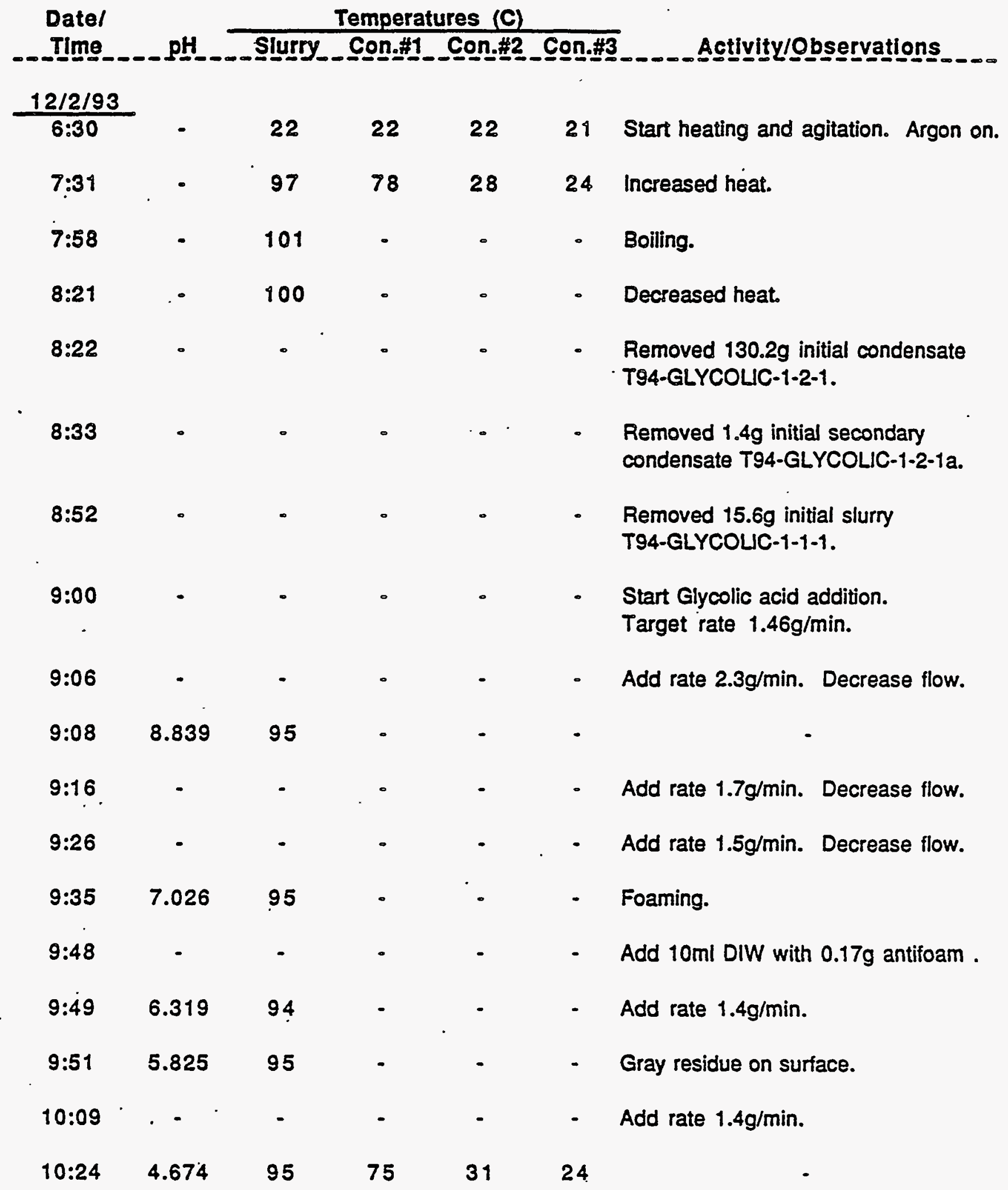

Page 1 


\begin{tabular}{|c|c|c|c|c|c|c|}
\hline \multirow{2}{*}{$\begin{array}{l}\text { Datel } \\
\text { Time }\end{array}$} & \multicolumn{5}{|c|}{ Temperatures (C) } & \multirow[b]{2}{*}{ Activity/Observations. } \\
\hline & PH & Slurry. & on.\# & Son. & on.\#3 & \\
\hline \multicolumn{7}{|l|}{$12 / 2 / 93$} \\
\hline $11: 05$ & - & - & - & - & - & $\begin{array}{l}\text { Removed } 186.4 \mathrm{~g} \text { acid addition } \\
\text { condensate T94-GLYCOLIC-1-2-2. }\end{array}$ \\
\hline $11: 27$ & 3.200 & 95 & 77 & 32 & 25 & Gray residue on smooth surface. \\
\hline $12: 01$ & 2.700 & 95 & $\cdot$ & - & - & Glycolic acid addition complete. \\
\hline $12: 05$ & - & - & - & - & - & $\begin{array}{l}\text { Removed } 17 \mathrm{~g} \text { acid addition slurry } \\
\text { T94-GLYC-1-1-2. }\end{array}$ \\
\hline $12: 10$ & - & - & - & - & - & $\begin{array}{l}\text { Removed } 14.3 \mathrm{~g} \text { acid addition } \\
\text { secondary condensate } \\
\text { T94-GLYCOLIC-1-2-2a. }\end{array}$ \\
\hline $12: 16$ & 2.700 & 95 & 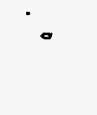 & - & - & $\begin{array}{l}\text { Increased heat for digestion. } \\
\text { Grayish white residue on surface. }\end{array}$ \\
\hline $12: 22$ & $\cdot$ & 101 & - & - & - & Boiling. Increased heat. \\
\hline 13:01 & 2.888 & 100 & - & - & $\cdot$ & $\begin{array}{l}\text { Removed } 150.1 \mathrm{~g} \text { condensate } \\
\text { T94-GLYC-1-2-3. Add } 150.1 \mathrm{~g} \text { DIW. }\end{array}$ \\
\hline 13:29 & 2.98 & 98 & - & - & - & $\begin{array}{l}\text { Removed } 78.4 \mathrm{~g} \text { condensate } \\
\text { T94-GLYC-1-2-3. Add } 78.4 \mathrm{~g} \text { DIW. }\end{array}$ \\
\hline $13: 53$ & - & - & - & - & $\cdot$ & $\begin{array}{l}\text { Removed } 80.6 \mathrm{~g} \text { condensate } \\
\text { T94-GLYC-1-2-3: Add } 80.6 \mathrm{~g} \text { DIW. }\end{array}$ \\
\hline $14: 10$ & $\cdot$ & - & . & . & $\cdot$ & $\begin{array}{l}\text { Removed } 75.7 \mathrm{~g} \text { condensate } \\
\text { T94-GLYC-1-2-3. Add } 75.7 \mathrm{~g} \text { DIW. }\end{array}$ \\
\hline $14: 38$. & 3.064 & 102 & - & - & & $\begin{array}{l}\text { Removed } 78.8 \mathrm{~g} \text { condensate } \\
\text { T94-GLYC-1-2-3. Add } 78.8 \mathrm{~g} \text { DIW. }\end{array}$ \\
\hline $14: 54$ & - & - & - & - & - & $\begin{array}{l}\text { Removed } 77.1 \mathrm{~g} \text { condensate } \\
\text { T94-GLYC-1-2-3. Add } 77.1 \mathrm{~g} \text { DIW. }\end{array}$ \\
\hline 15:29 & 3.149 & 98 & - & - & & $\begin{array}{l}\text { Removed } 84.5 \mathrm{~g} \text { condensate } \\
\text { T94-GLYC-1-2-3. Add } 84.5 \mathrm{~g} \text { DIW. }\end{array}$ \\
\hline
\end{tabular}


Activity Log - Test T94-GLYCOLIC-I

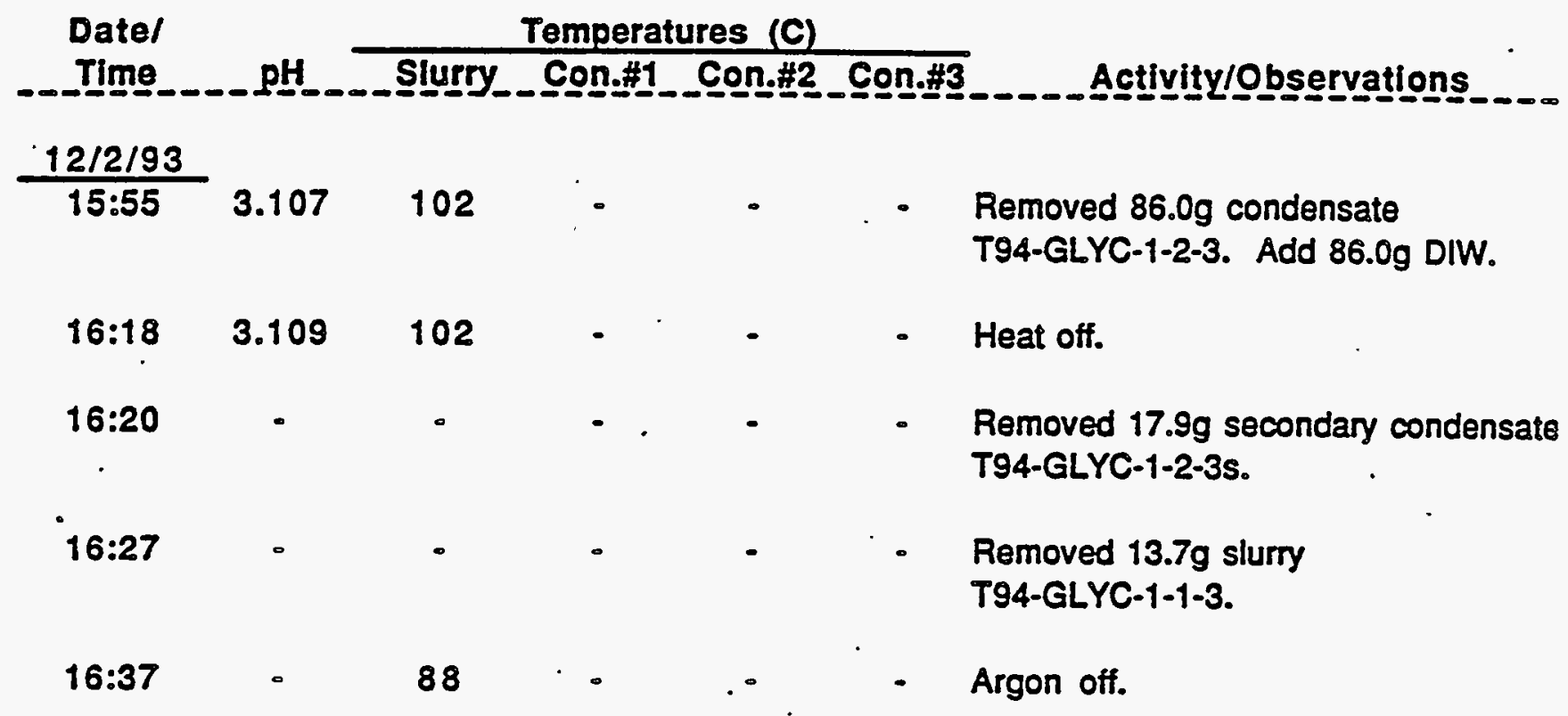




\section{Datel} Time pH
Temperatures (C)

Slurry_Con:\#1_Con.\#2_Con.\#3

\section{Activity/Observations}

$2 / 23 / 94$

$6: 30$

11.72

24

24

25

$6: 40$

11.77

25

$6: 45$

11.60

33

52

$.6: 55$

$7: 00$

10.77

66

$7: 10 \quad 10.12$

$7: 20$

9.5

97

97

$7: 25$

9.27

8.63

101

89

8:02

8:03

$8: 15$

$8: 38$

$8: 44$

9.36

$8: 51$

9.45

$9: 10$

$9: 13$

9.55

$9: 14$

$9: 16$
95

94

81

101

91

$\cdots$

-

79

26

$\cdot$

32
24 Start agitation. Argon on.

24 Start heating. Reflux condensate.

2424 . No apparent change in density.

2525 No apparent change in density.

2025 No apparent change in density.

2525 No apparent change in density.

2625 No apparent change in density.

2626 Increased heat.

$25 \quad 24$ Boiling.

- Removed pH probe for calibration.

- $\quad$ Slurry appears to be fluid.

2524 Decreased heat.

- Removed $16.0 \mathrm{~g}$ of slumy T94-FPGLYC-1-1-1.

- $\quad$ Added $5 \mathrm{ml}$ DIW with $0.19 \mathrm{~g}$ antifoam. Placed $\mathrm{pH}$ probe in slurry.

25 Hooked up gas analyzer.

- Started Glycolic acid addition.

Target rate $1.7 \mathrm{~g} / \mathrm{min}$.

26 Add rate $2.3 \mathrm{~g} / \mathrm{min}$. Decreased flow.

- Add rate $2.0 \mathrm{~g} / \mathrm{min}$. Decreased flow.

- Add rate $2.0 \mathrm{~g} / \mathrm{min}$. Decreased flow. 


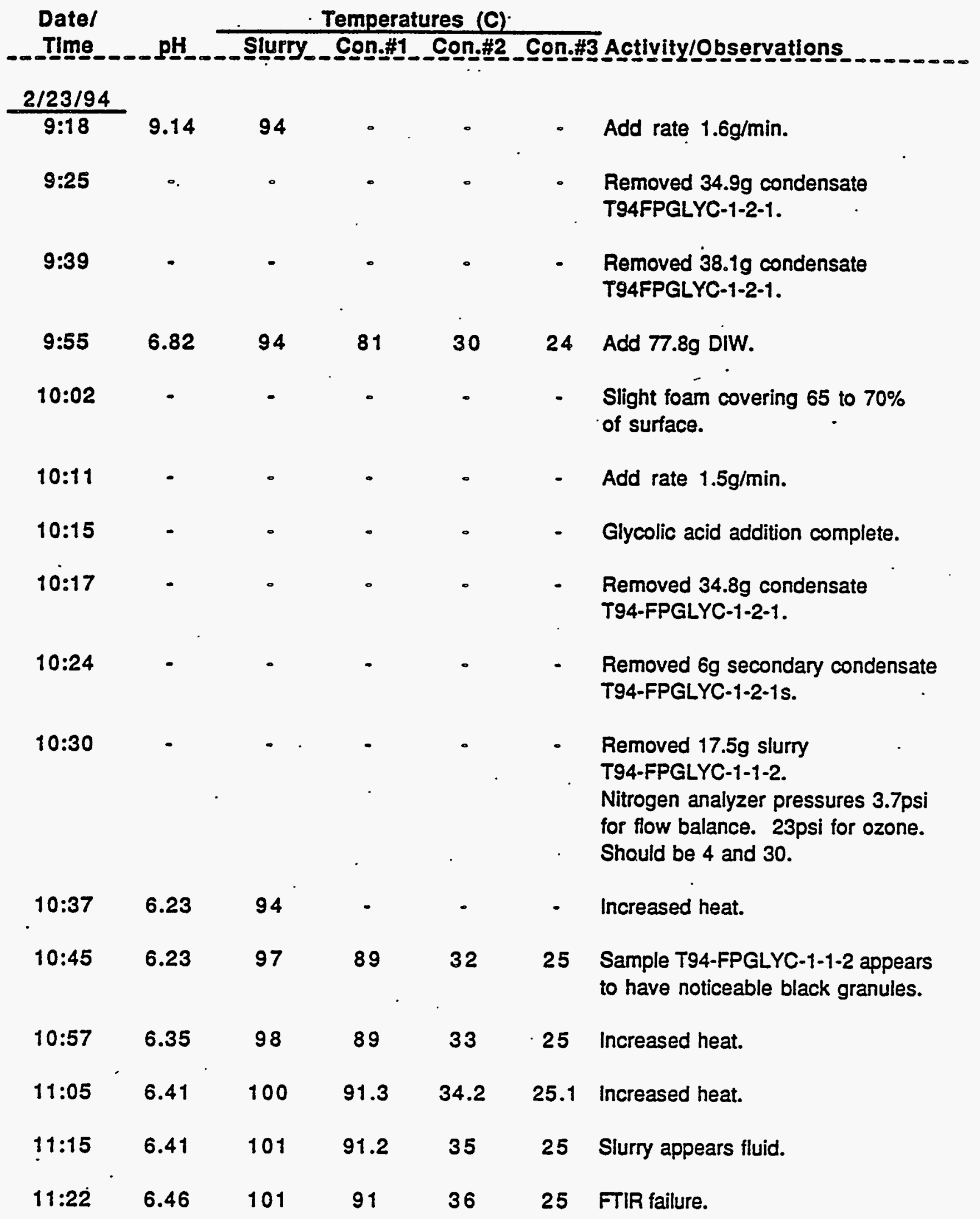




\begin{tabular}{|c|c|c|c|c|c|c|}
\hline \multirow{2}{*}{$\begin{array}{l}\text { Datel } \\
\text { Time } \\
2 / 23 / 94\end{array}$} & & \multicolumn{4}{|c|}{ Temperatures (C) } & \multirow{2}{*}{ Activity/Observations } \\
\hline & & & & & & \\
\hline $11: 24$ & . & - & - & - & $\therefore$ & $\begin{array}{l}\text { Removed } 155.49 \text { condensate } \\
\text { T94-FPGLYC-1-2-2. }\end{array}$ \\
\hline $11: 28$ & - & - & - & - & - & Slight foaming. \\
\hline $11: 35$ & 6.51 & 102 & 91 & 35 & 23 & $\begin{array}{l}\text { Removed } 39.5 \mathrm{~g} \text { condensate } \\
\text { T94-FPGLYC-1-2-2. }\end{array}$ \\
\hline $11: 47$ & - & - & - & - & - & $\begin{array}{l}\text { Removed } 39.4 \mathrm{~g} \text { condensate } \\
\text { T94-FPGLYC-1-2-2. }\end{array}$ \\
\hline $11: 53$ & - & 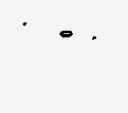 & - & - & - & $\begin{array}{l}\text { Removed } 38.49 \text { condensate } \\
\text { T94-FPGLYC-1-2-2. }\end{array}$ \\
\hline $11: 55$ & 6.6 & 103 & 91 & 37 & 25 & Slight foaming. \\
\hline $11: 58$ & - & - &. & - & - & $\begin{array}{l}\text { Removed } 30.2 \mathrm{~g} \text { condensate } \\
\text { T94-FPGLYC-1-2-2. }\end{array}$ \\
\hline $12: 07$ & - & - & - & - & - & $\begin{array}{l}\text { Foam covering about } 70 \% \text { of surface } \\
\text { area. }\end{array}$ \\
\hline $12: 09$ & - & - & - & - & - & $\begin{array}{l}\text { Removed } 38.9 \mathrm{~g} \text { of condensate } \\
\text { T94-FPGLYC-1-2-2. }\end{array}$ \\
\hline $12: 12$ & - & $:$ & - & - & - & $\begin{array}{l}\text { Removed } 18.4 \mathrm{~g} \text { of condensate } \\
\text { T94-FPGLYC-1-2-2. }\end{array}$ \\
\hline $12: 18$ & 6.76 & 1.03 & - & - & - & $\begin{array}{l}\text { Removed } 10.7 \mathrm{~g} \text { secondary condensate } \\
\text { T94-FPGLYC-1-2-2s. } \\
\text { Started refluxing. }\end{array}$ \\
\hline $12: 24$ & - & $\cdot$ & - & - & - & Add $17 \mathrm{~g}$ DIW. \\
\hline $12: 34$ & 6.84 & 103 & 91 & 40 & 26 & Slight foaming. \\
\hline $12: 46$ & 6.85 & 103 & 92 & 41 & 26 & Slight foaming. \\
\hline $12: 55$ & 6.87 & 103 & 91 & 39 & 24 & $\begin{array}{l}\text { Slight foam. Black residue on surface. } \\
\text { Decreased heat. }\end{array}$ \\
\hline
\end{tabular}




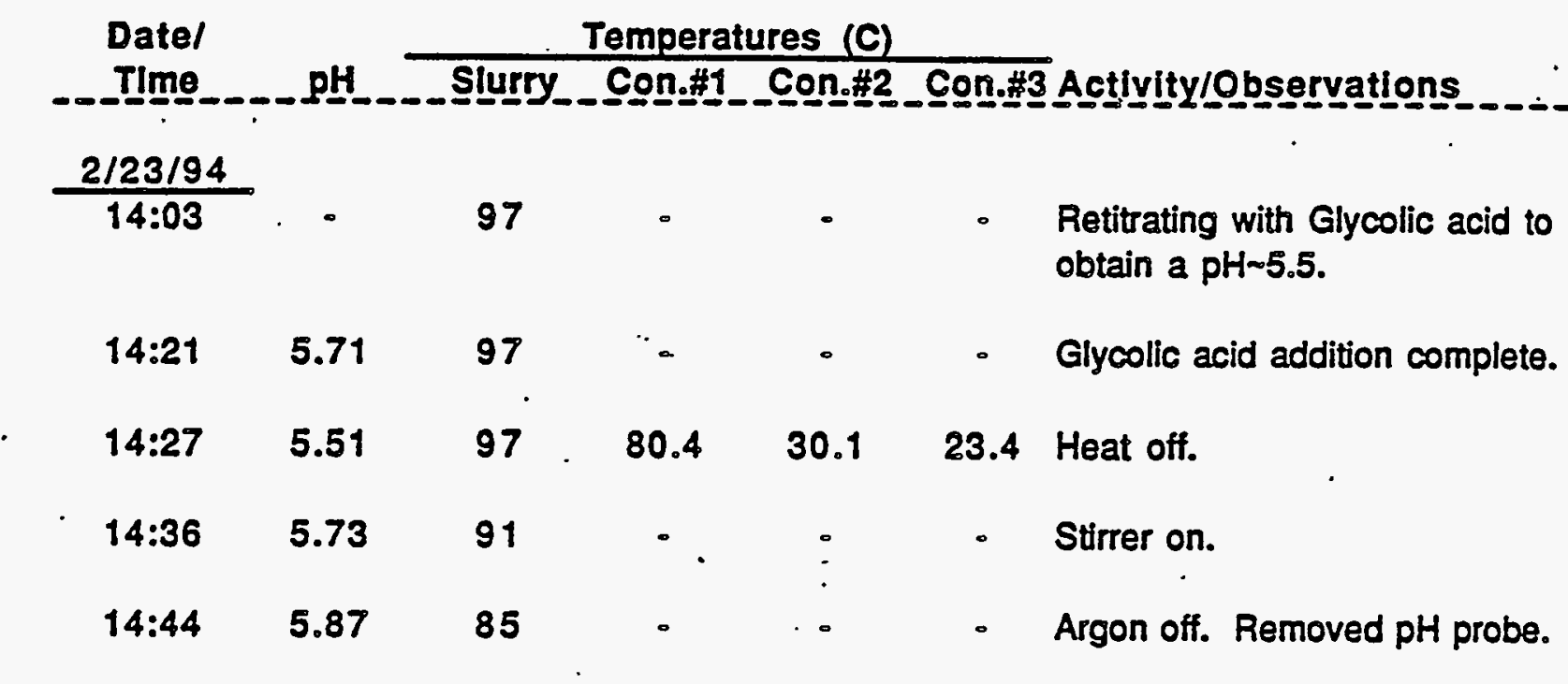




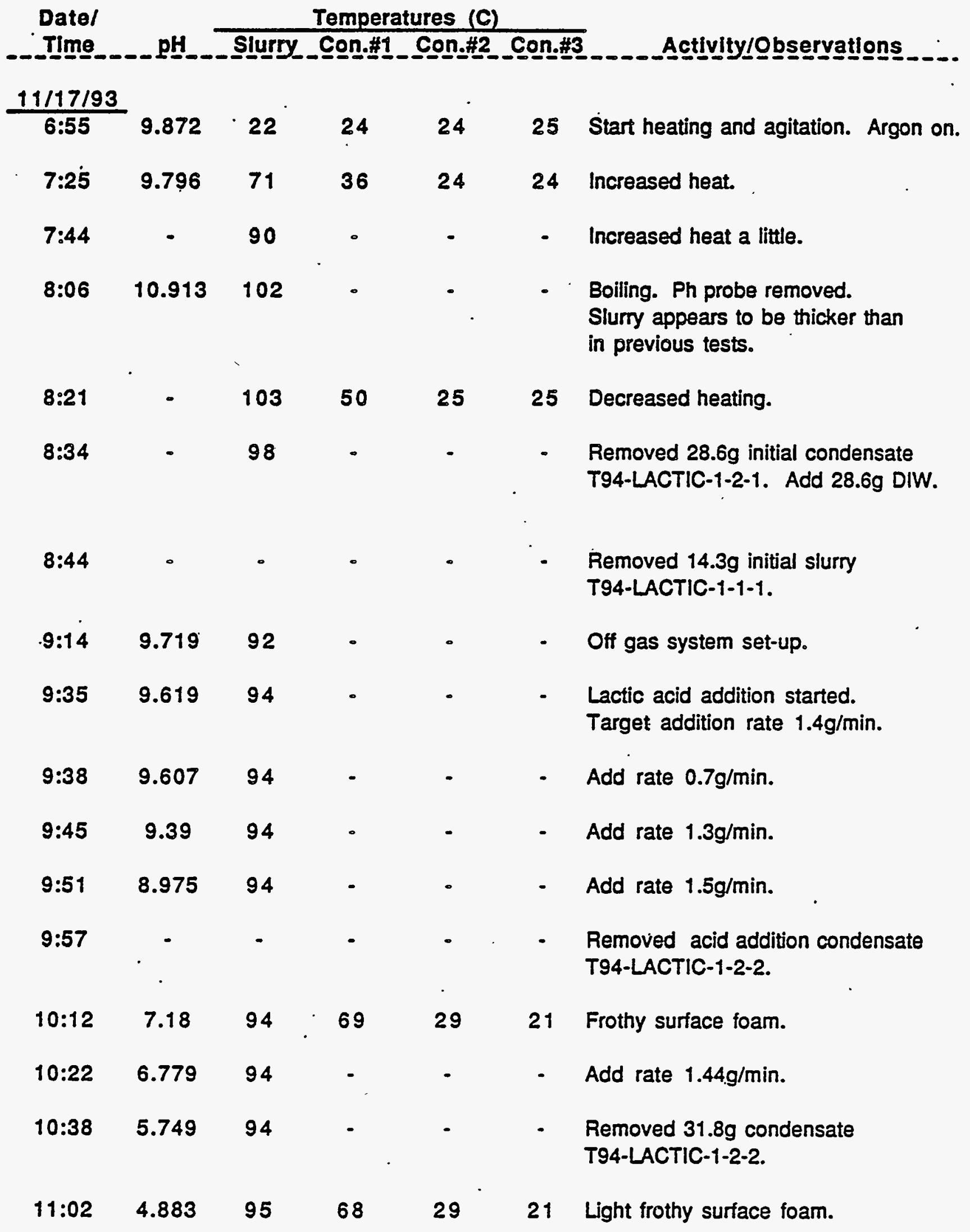




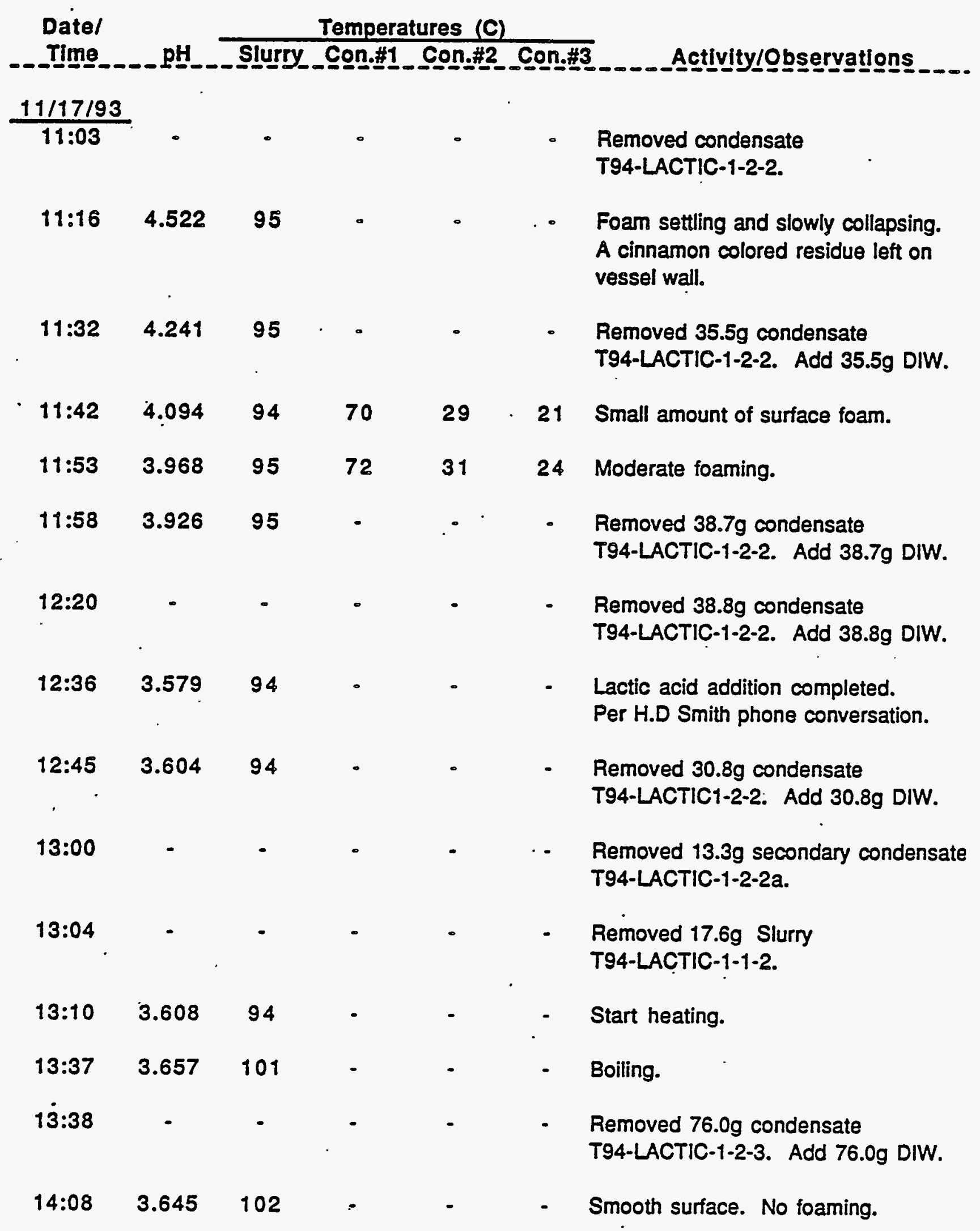




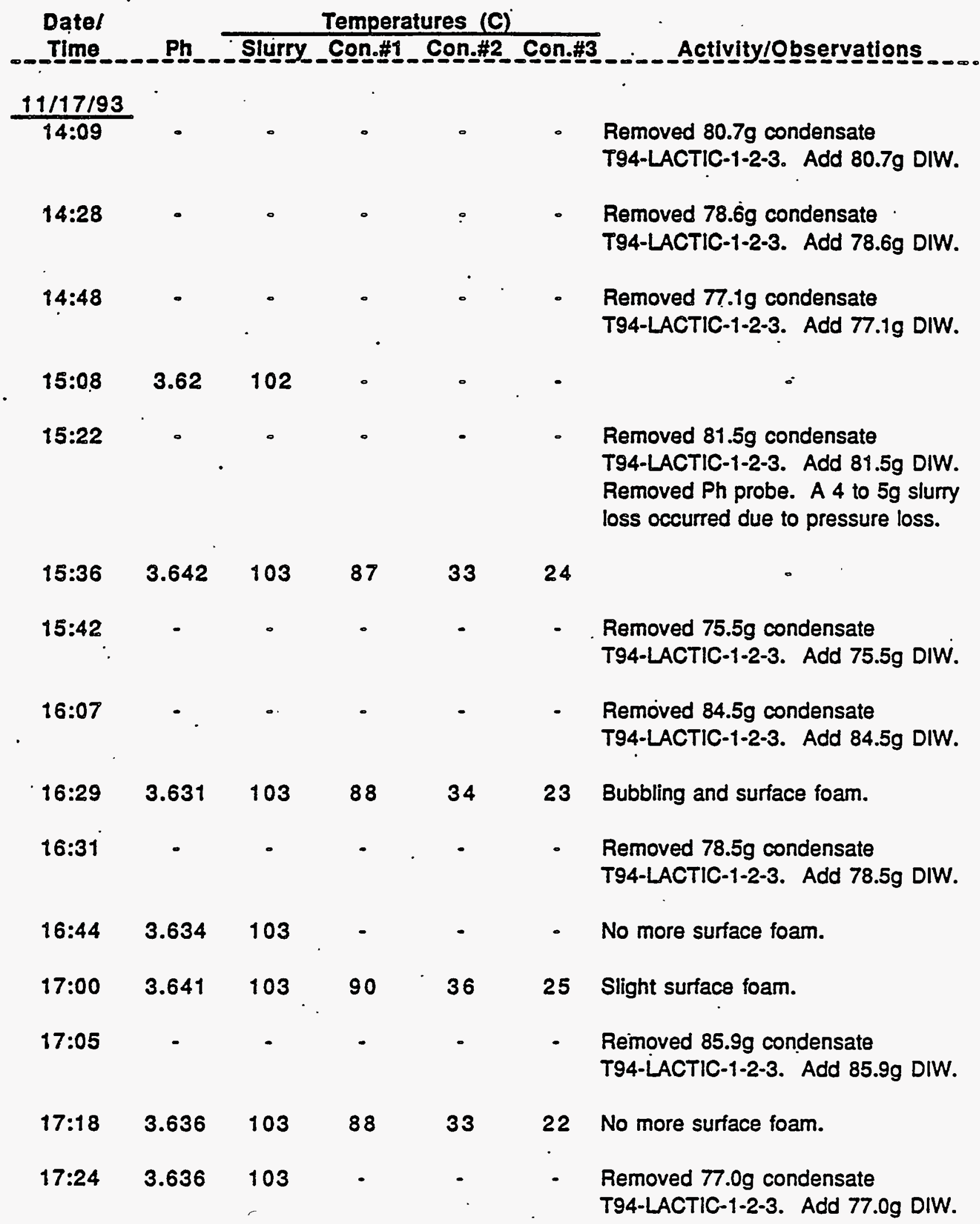




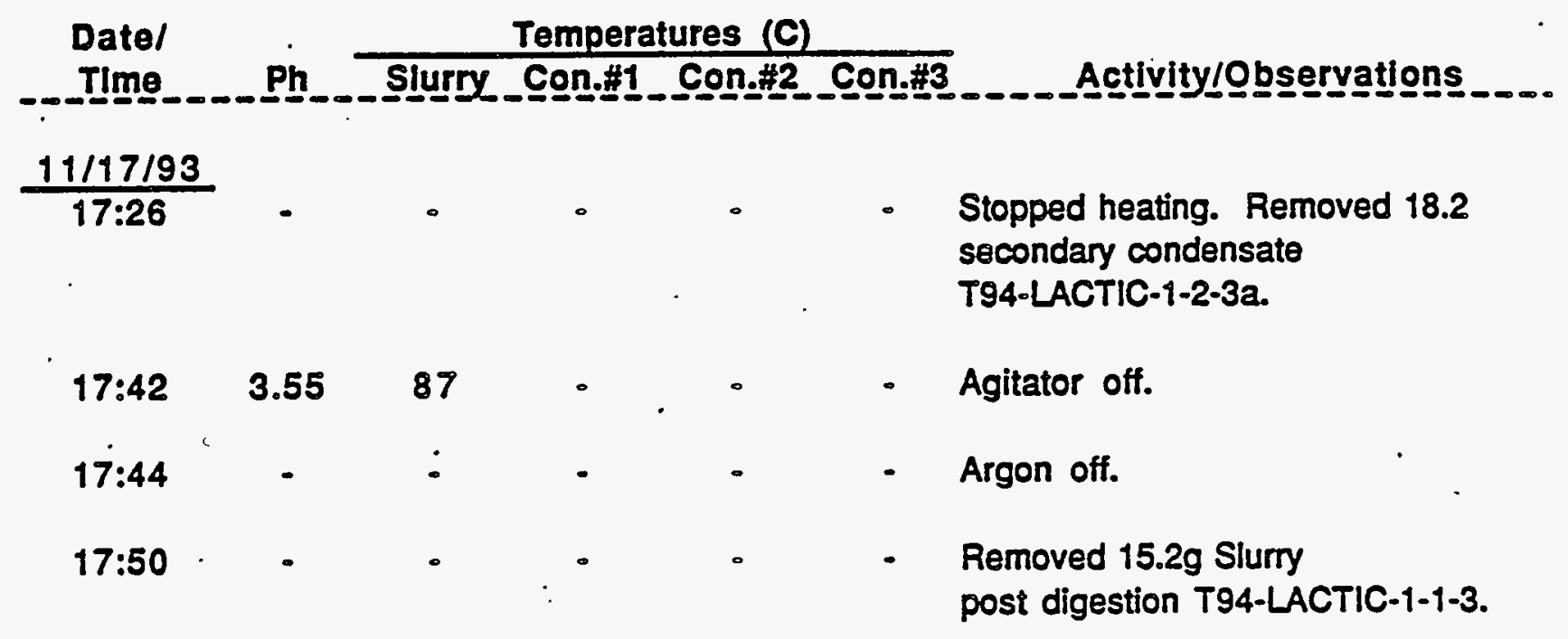


Activity Log - Test T94-HNO3-1

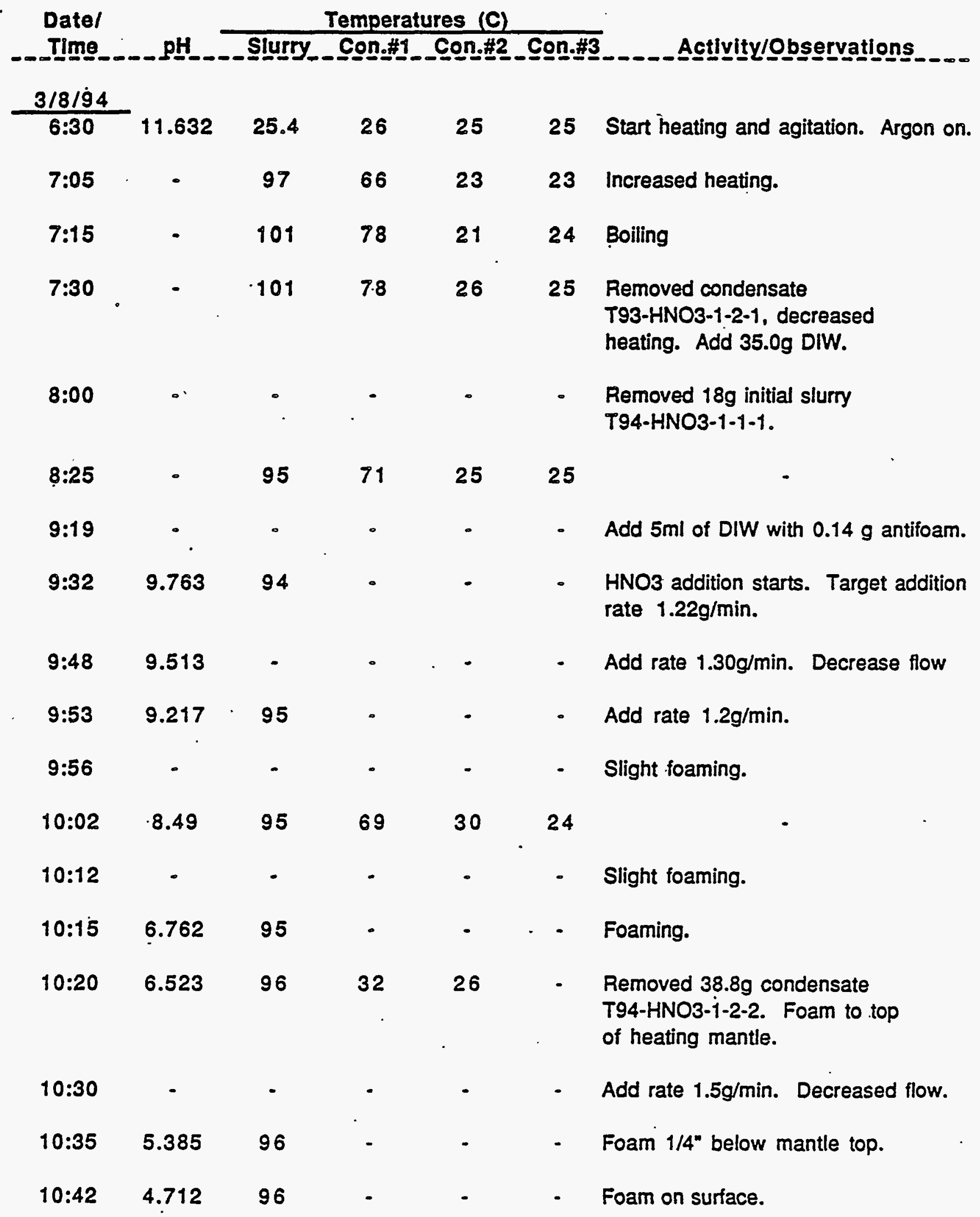




\begin{tabular}{|c|c|c|c|c|c|c|}
\hline \multirow{2}{*}{$\begin{array}{l}\text { Datel } \\
\text { Time }\end{array}$} & \multicolumn{6}{|c|}{ Temperatures (C) } \\
\hline & $\mathrm{pH}$ & Slurgs & ?n.t. & :on: & Son.fis & Activity/Observations. \\
\hline $3 / 8 / 94$ & & & & & & \\
\hline $10: 47$ & 4.423 & 96 & - & - & - & Foam approximately $1 / 2^{\prime \prime}$. \\
\hline $10: 51$ & 4.019 & 96 & . & - & . & Foam breaking up. \\
\hline $11: 02$ & 3.502 & 95 & - & 29 & 23 & $\begin{array}{l}\text { Removed } 39.8 \mathrm{~g} \text { of condensate } \\
\text { T94-HNO3-1-2-2. }\end{array}$ \\
\hline $11: 06$ & 3.43 & - & - & - & - & $\begin{array}{l}\text { HNO3 addition stopped. Island of } \\
\text { foam around center shaft. }\end{array}$ \\
\hline $11: 16$ & 3.645 & - & . & . & - & HNO3 addition started. \\
\hline $11: 23$ & 3.204 & 95 & - & - & - & HNO3 addition stopped. \\
\hline $11: 34$ & - & - & - & . & . & $\begin{array}{l}\text { Removed } 37.7 \mathrm{~g} \text { of condensate } \\
\text { T94-HNO3-1-2-2. }\end{array}$ \\
\hline $11: 30$ & 3.437 & - & . & - & - & HNO3 addition started. \\
\hline $11: 37$ & 3.038 & 96 & - & - & - & Slight surface foam. \\
\hline $11: 41$ & 2.866 & - & - & - & - & Nice red brown color and fluid. \\
\hline $11: 45$ & 2.742 & 95 & 65 & 29 & 24 & $\begin{array}{l}\text { HNO3 addition completed. Increased } \\
\text { heating. Grayish colored surface } \\
\text { foam around center shaft. } \\
\text { Refluxing condensate. Removed } 91.3 \mathrm{c} \\
\text { conderisate T94-HNO3-1-2-2. }\end{array}$ \\
\hline $11: 50$ & - & - & - & - & - & $\begin{array}{l}\text { Removed } 10.7 \mathrm{~g} \text { secondary condensate } \\
\text { T94-HNOS-1-2-2s. }\end{array}$ \\
\hline $12: 05$ & - & - & - & - & $\cdot$ & $\begin{array}{l}\text { Removed } 17 \mathrm{~g} \text { acid addition slurry } \\
\text { T94-HNO3-1-1-2. }\end{array}$ \\
\hline $12: 15$ & 3.163 & 99 & 73 & 30 & 30 & - \\
\hline $12: 45$ & 3.343 & 102 & 80 & 23 & 23 & - \\
\hline 13:00 & 3.38 & 102 & 81 & 29 & 23 & ting condensate. \\
\hline
\end{tabular}




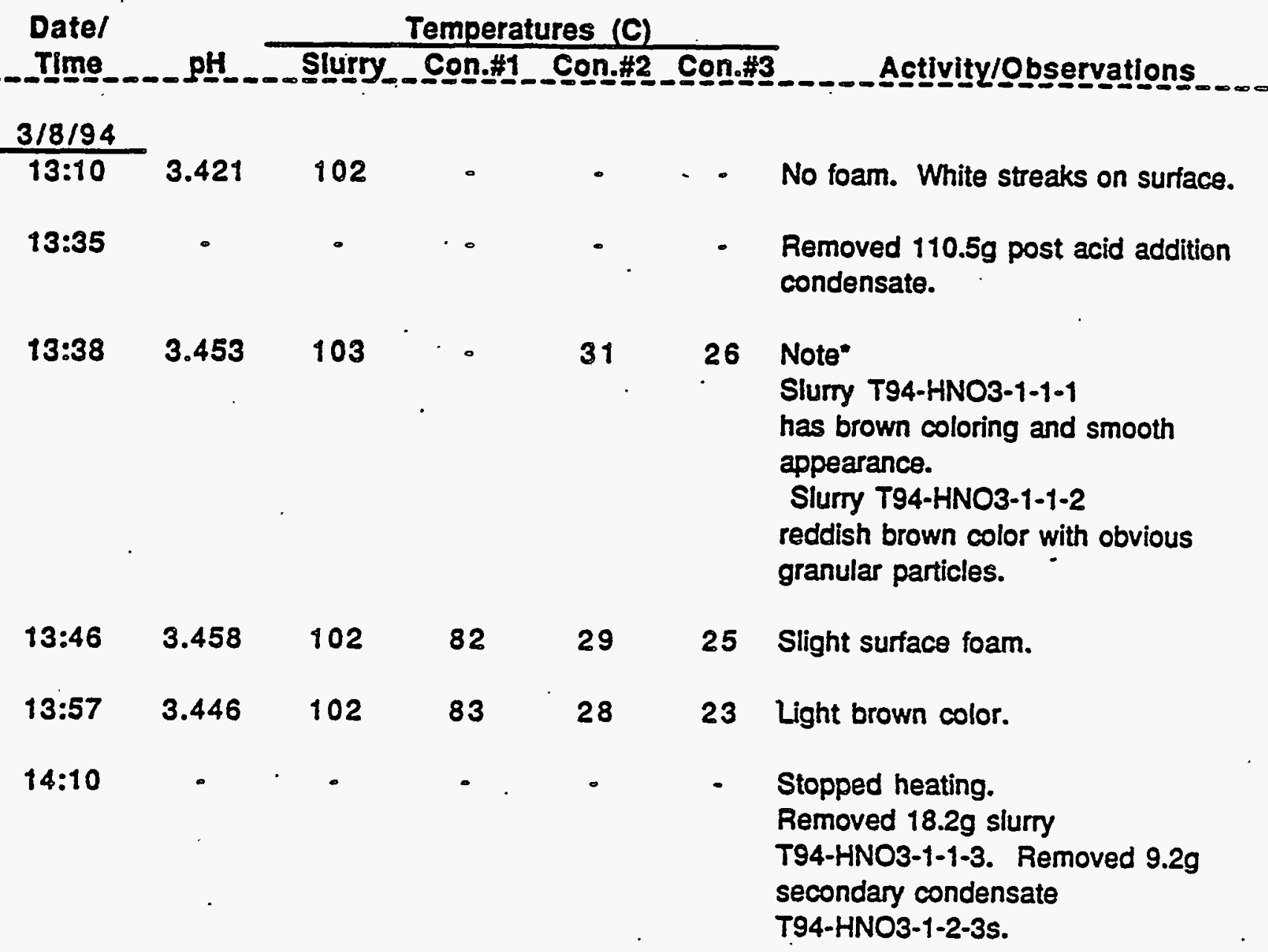

14:22 $3.462 \cdot 85 \quad-\quad-\quad$ - Agitator off. Argon off.


PAGE 1 of 10

Laboratory-Scale Melter Feed Preparation Activity Log

Nitric Acid Addition, Test-T95-FPHNO3-1

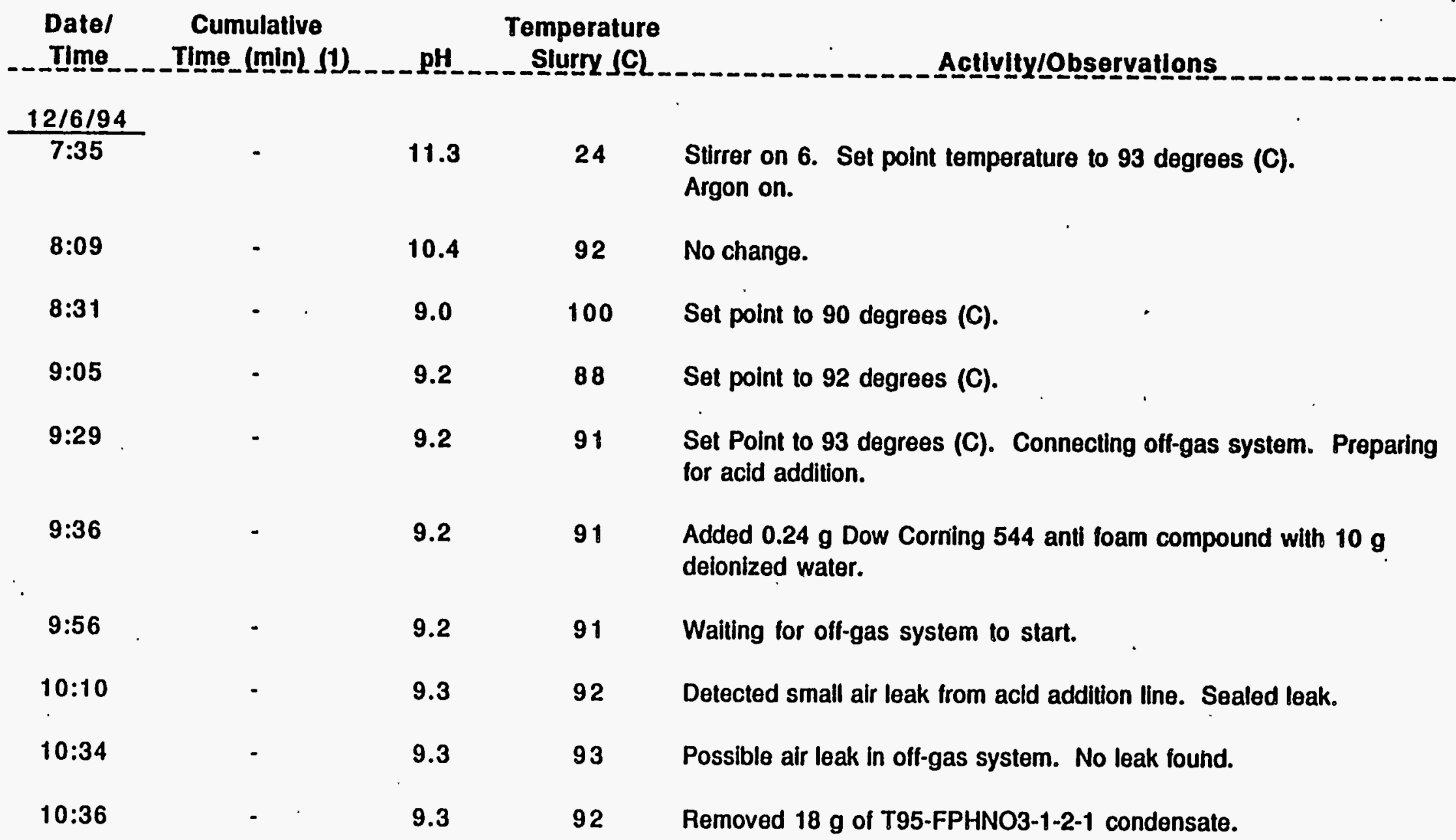




\section{Laboratory-Scalo Melter Feed Preparation Activity Log}

Nitric Acld Addition, Test-T95-FPHNO3-1

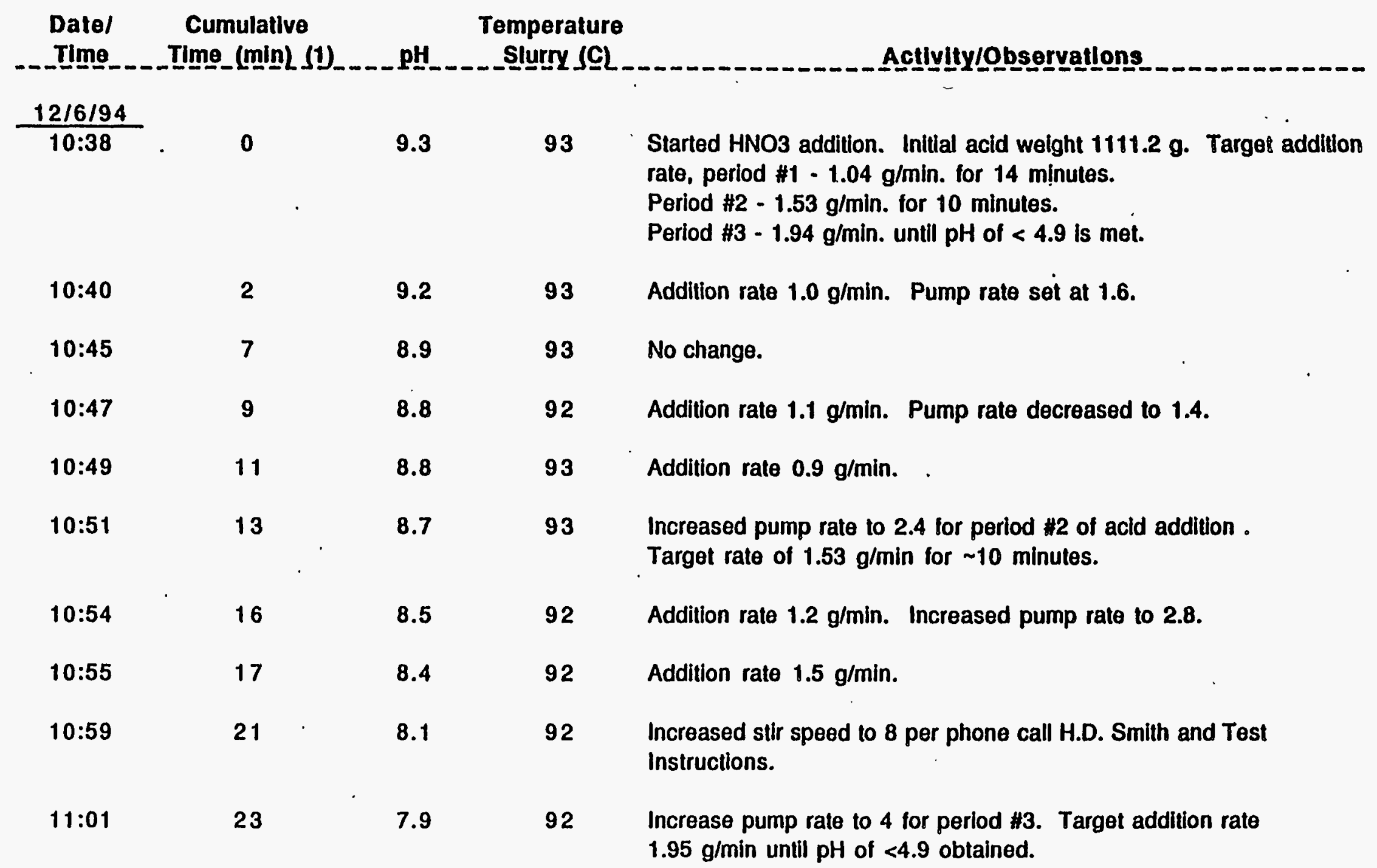


PAGE 3 of 10

Laboratory-Scalo Meltẹr Feed Preparation Activity Log

Nitric Acid Addition, Test-T95-FPHNO3-1

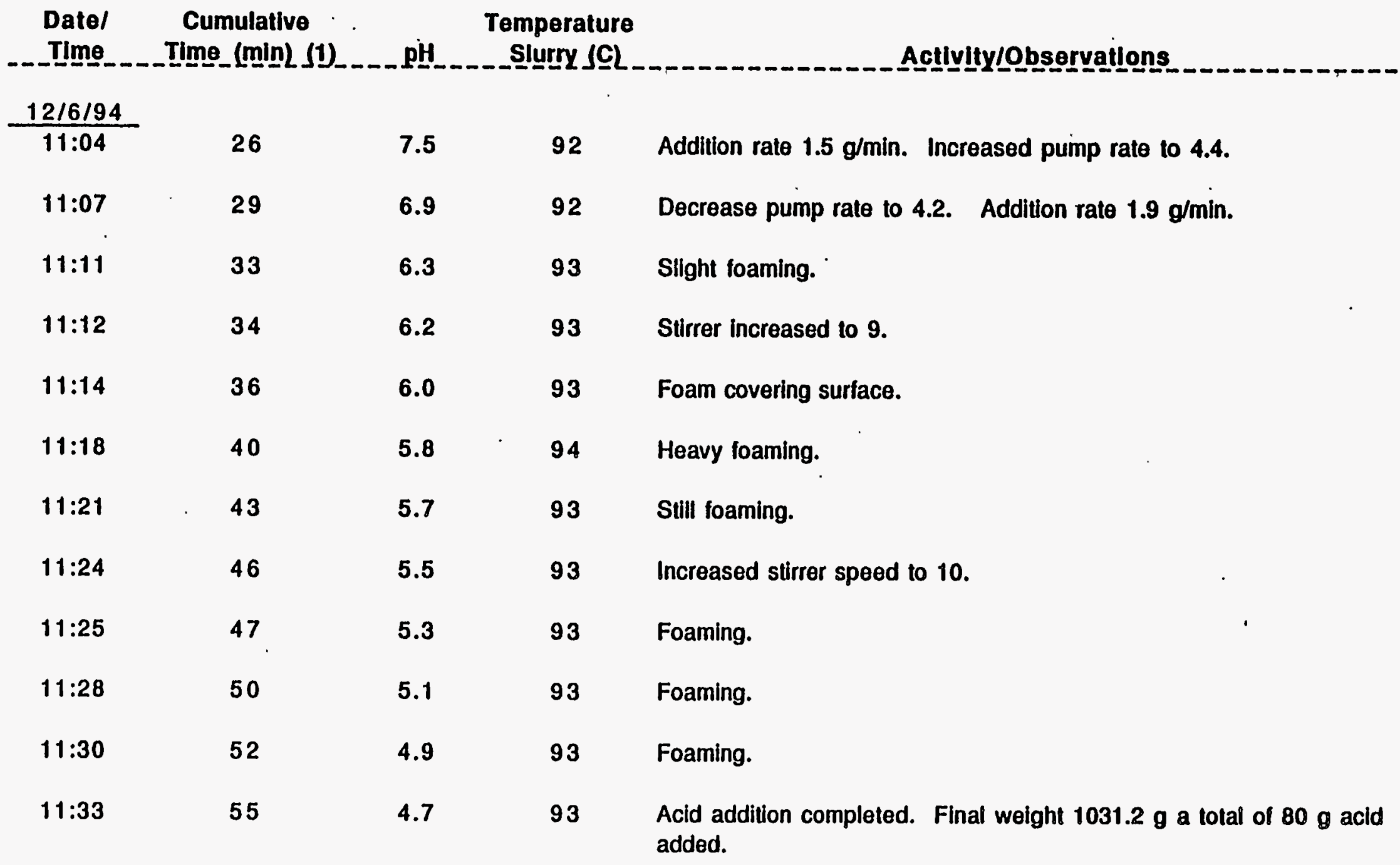


Nitric Acld Addition, Test-T95-FPHNO3-1

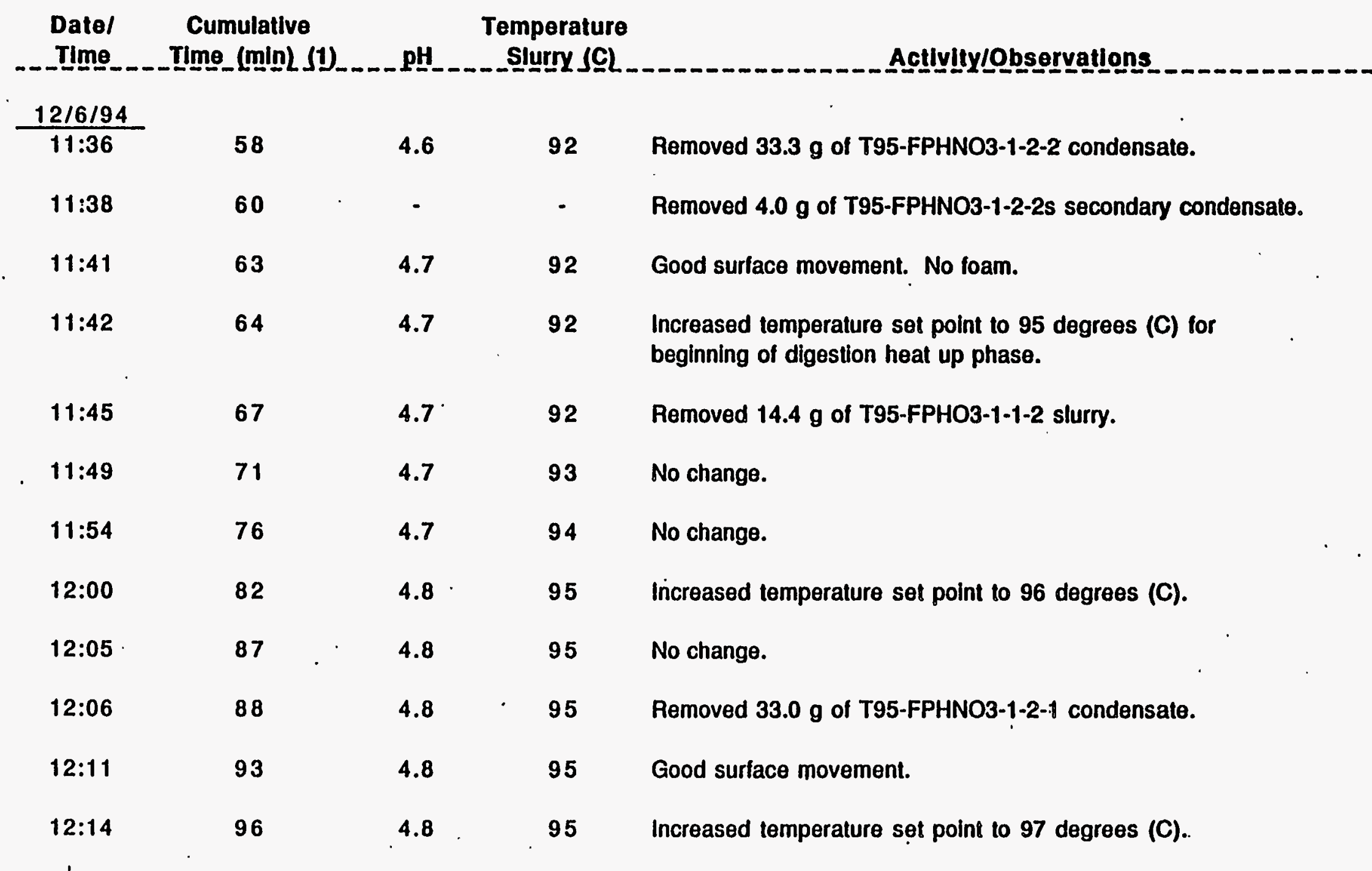


Nitric Acld Addition, Test-T95-FPHNO3-1

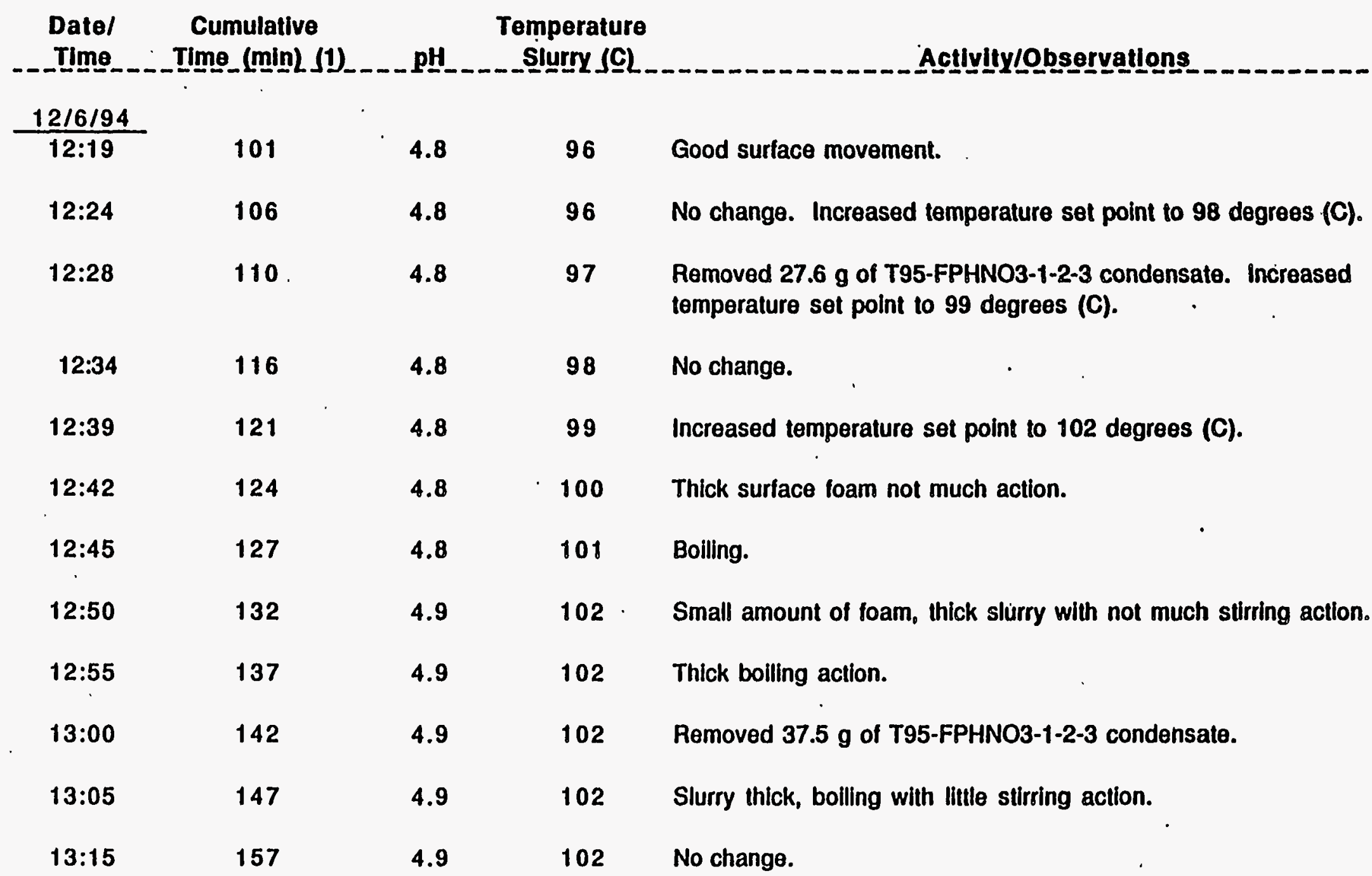


Nitric Acid Addition, Test-T95-FPHNO3-1

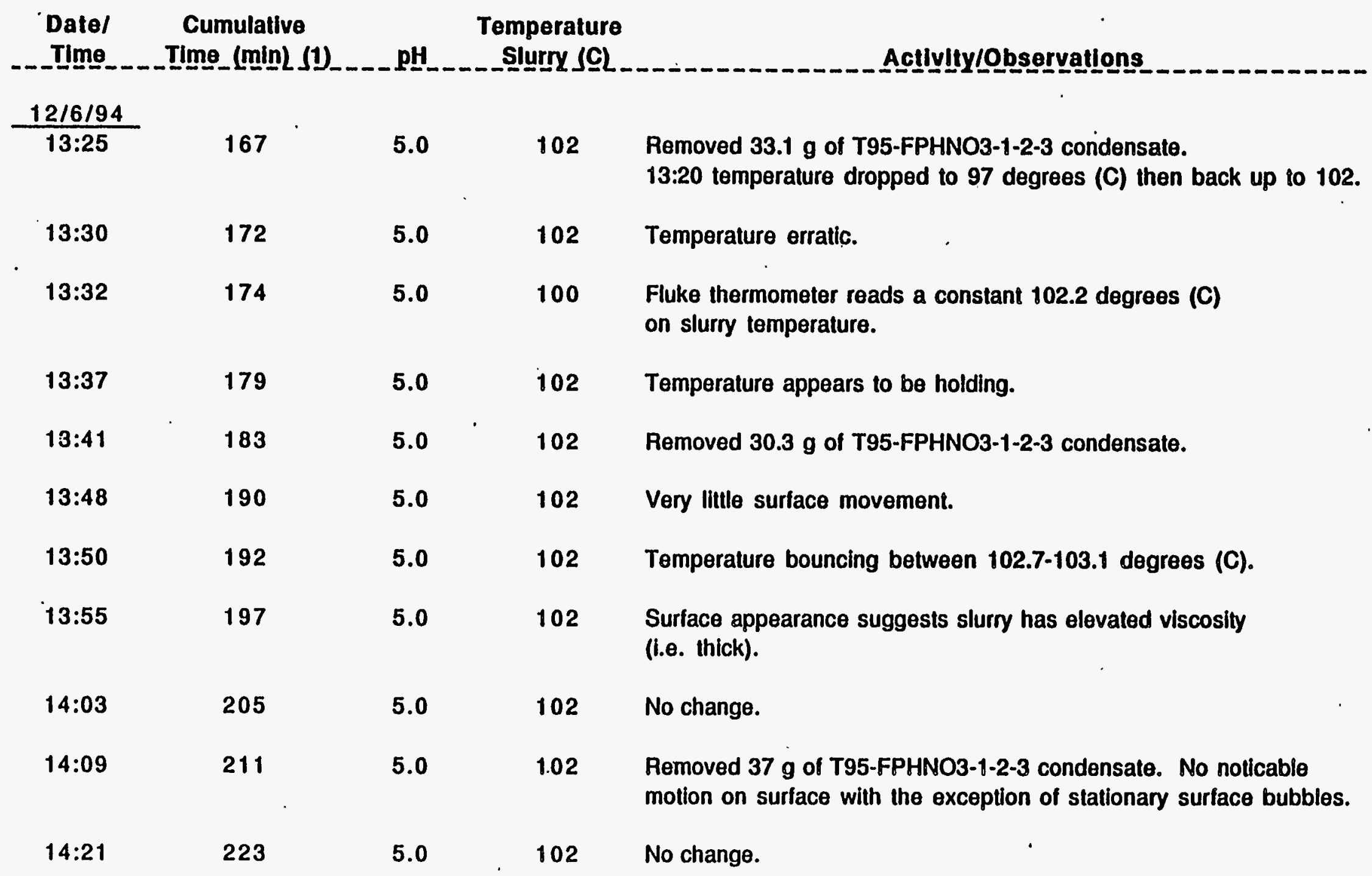




\section{PAGE 7 of 10}

\section{Laboratory-Scale Melter Feed Preparation. Activlty Log}

Nitrlc Acid Addition, Test-T95-FPHNO3-1

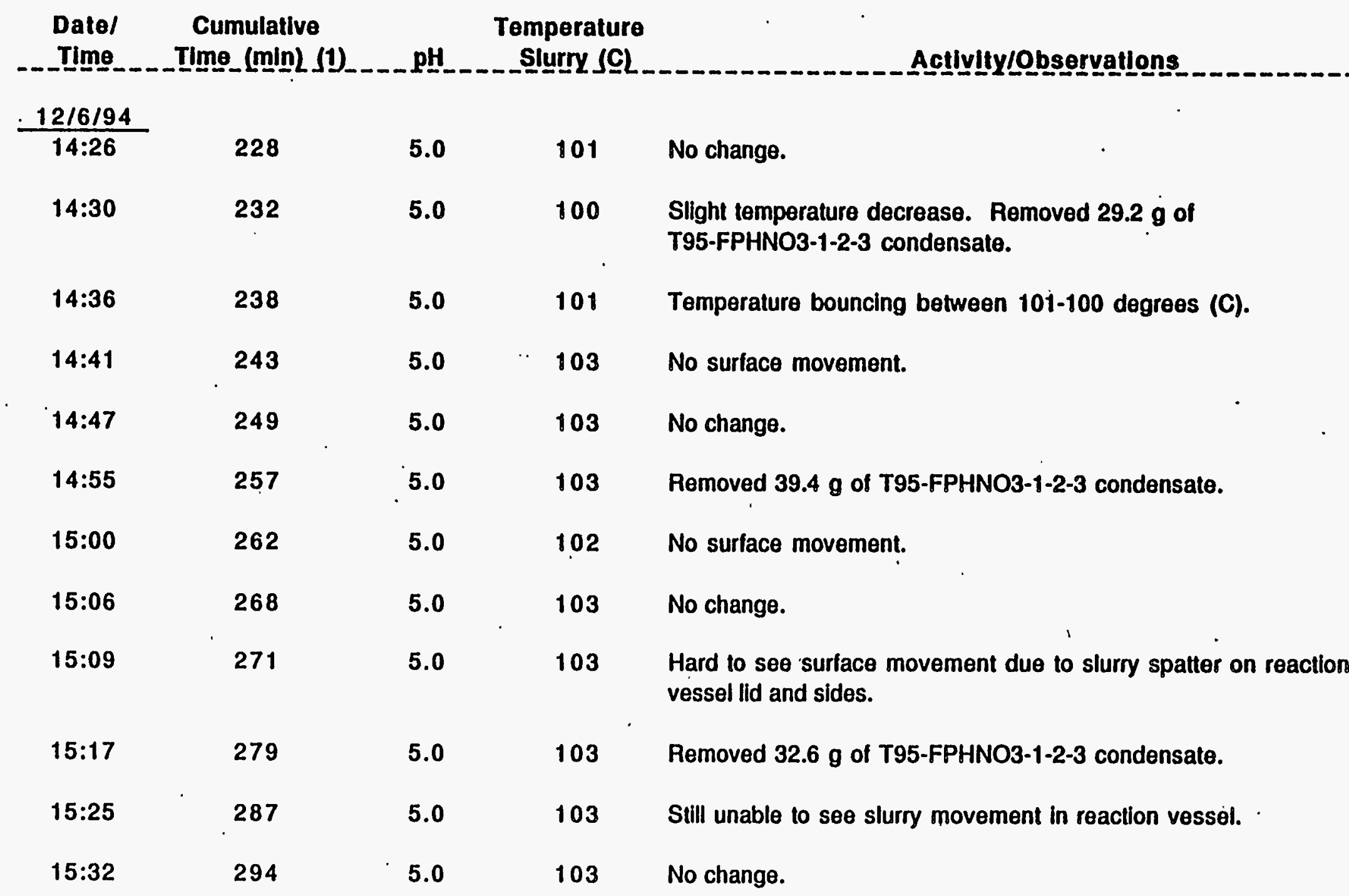




\section{PAGE 8 of 10}

\section{Laboratory-Scale Melter Feed Preparation Activity Log}

Nitric Acld Addition, Test-T95-FPHNO3-1

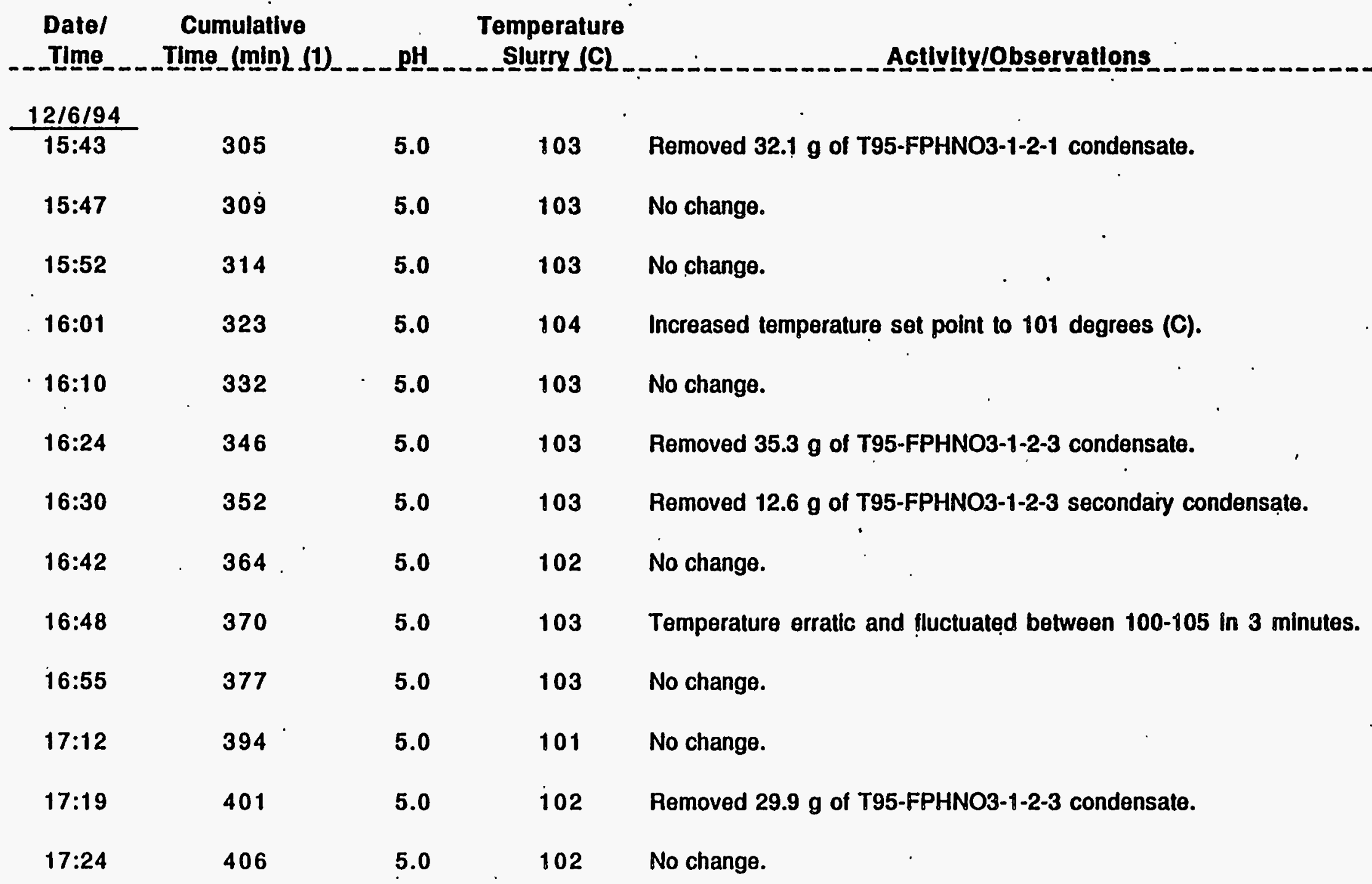


PAGE 9 of 10

Laboratory-Scale Melter Feed Preparation Activity Log

Nitric Acld Addition, Test-T95-FPHNO3-1

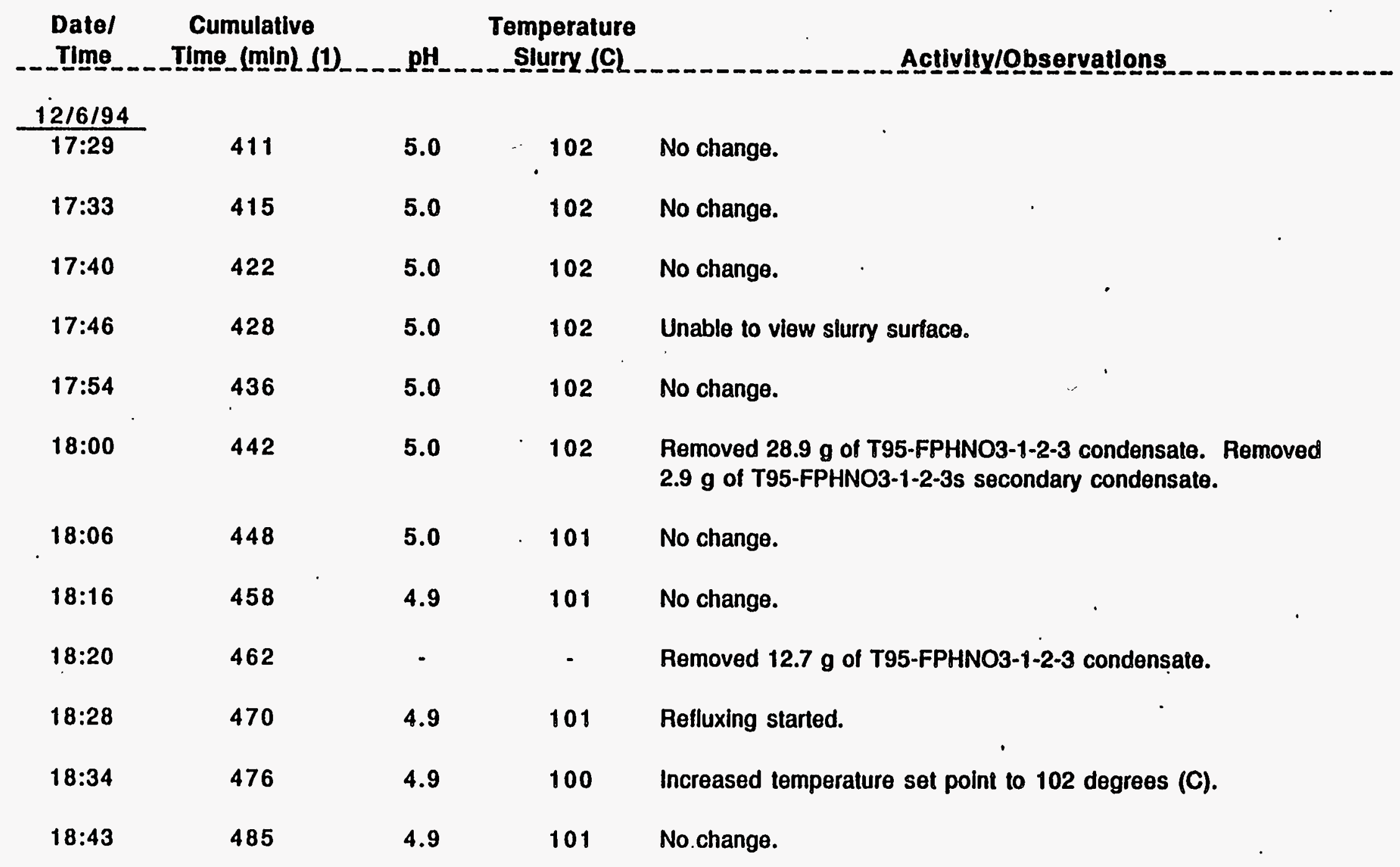


PAGE 10 of 10

Laboratory-Scale Melter Feed Preparation Activity LOg

Nitric Acid Addition, Test-T95-FPHNO3-t

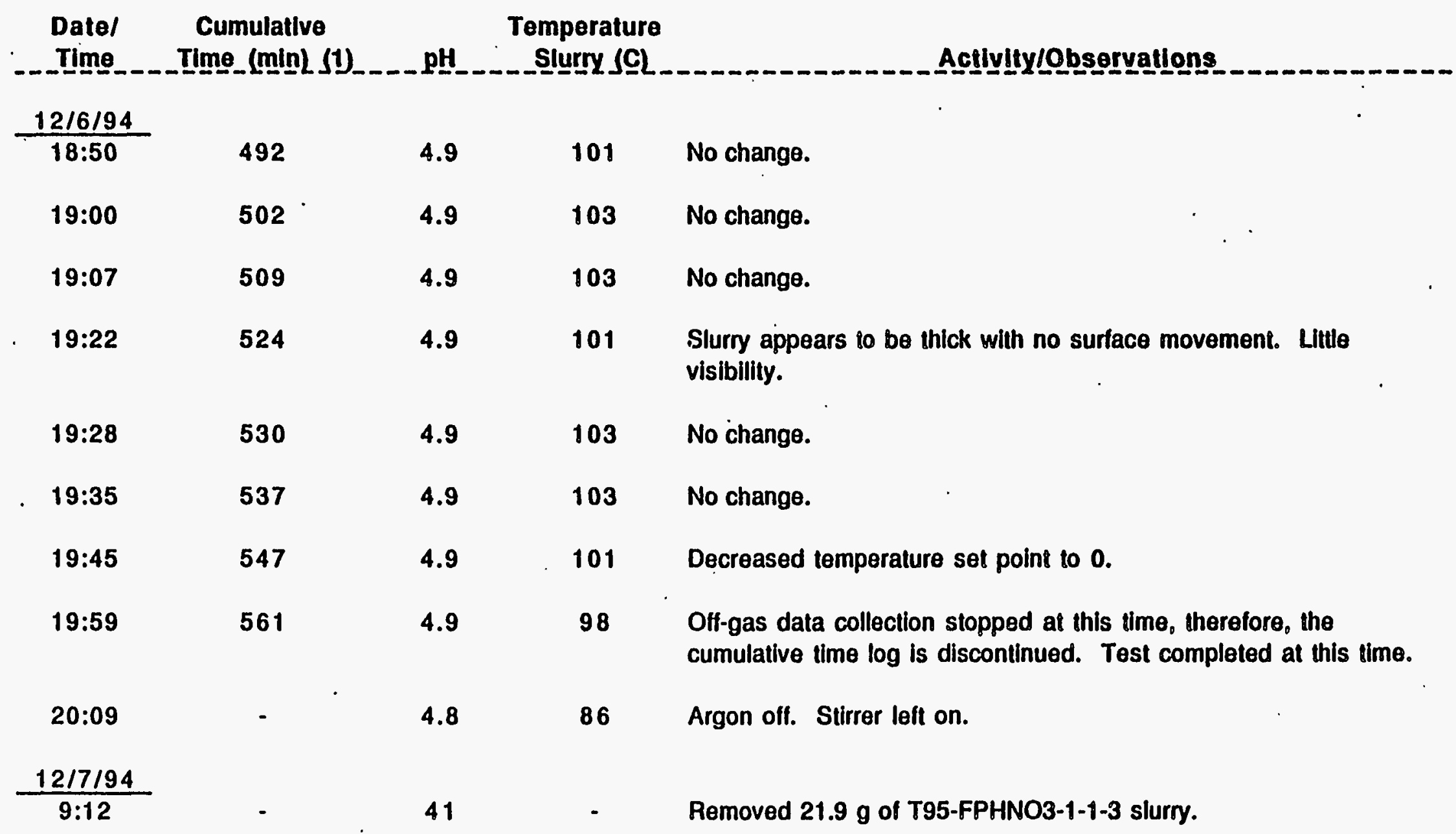

1. Time after initiation of acid addition (min). 


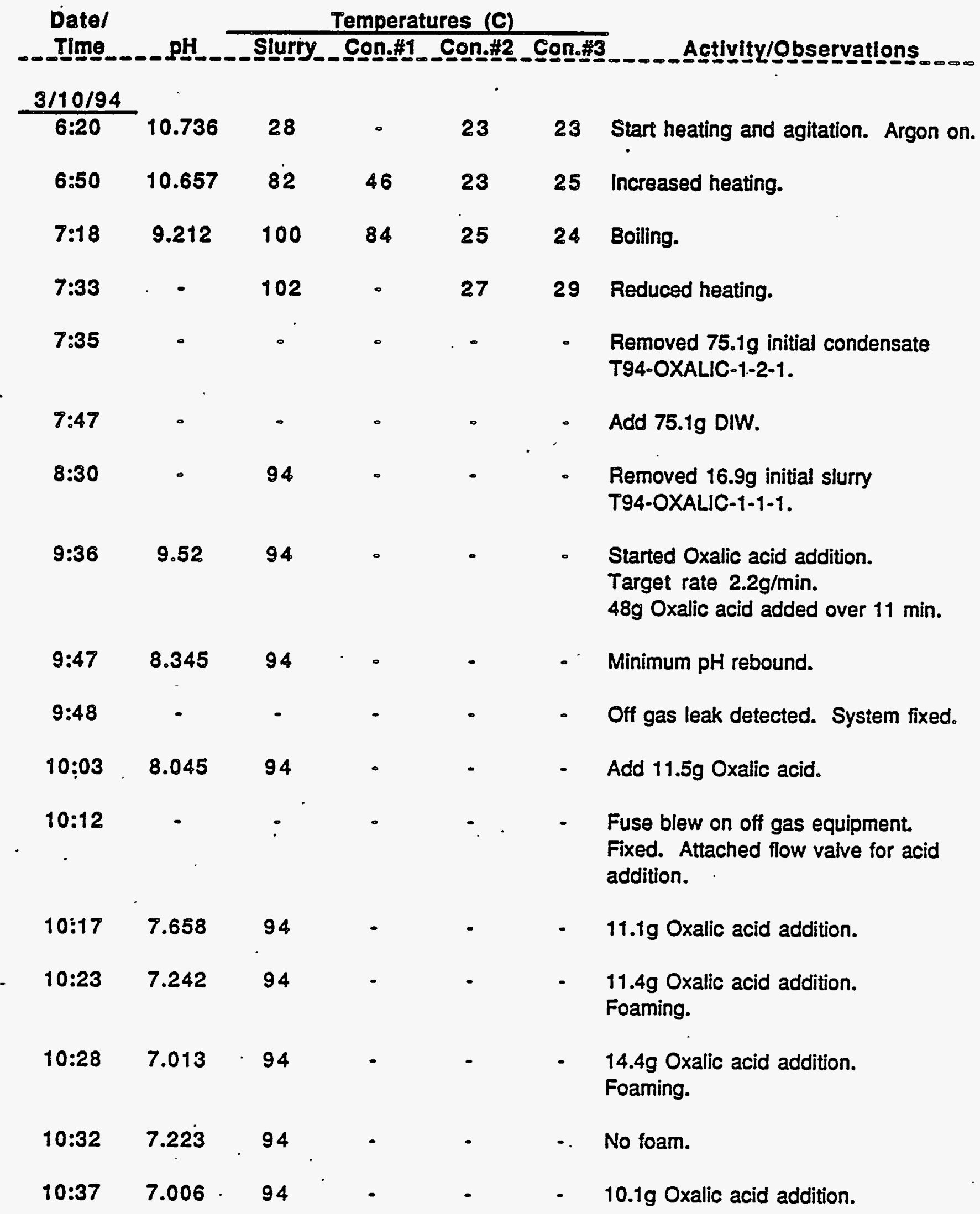




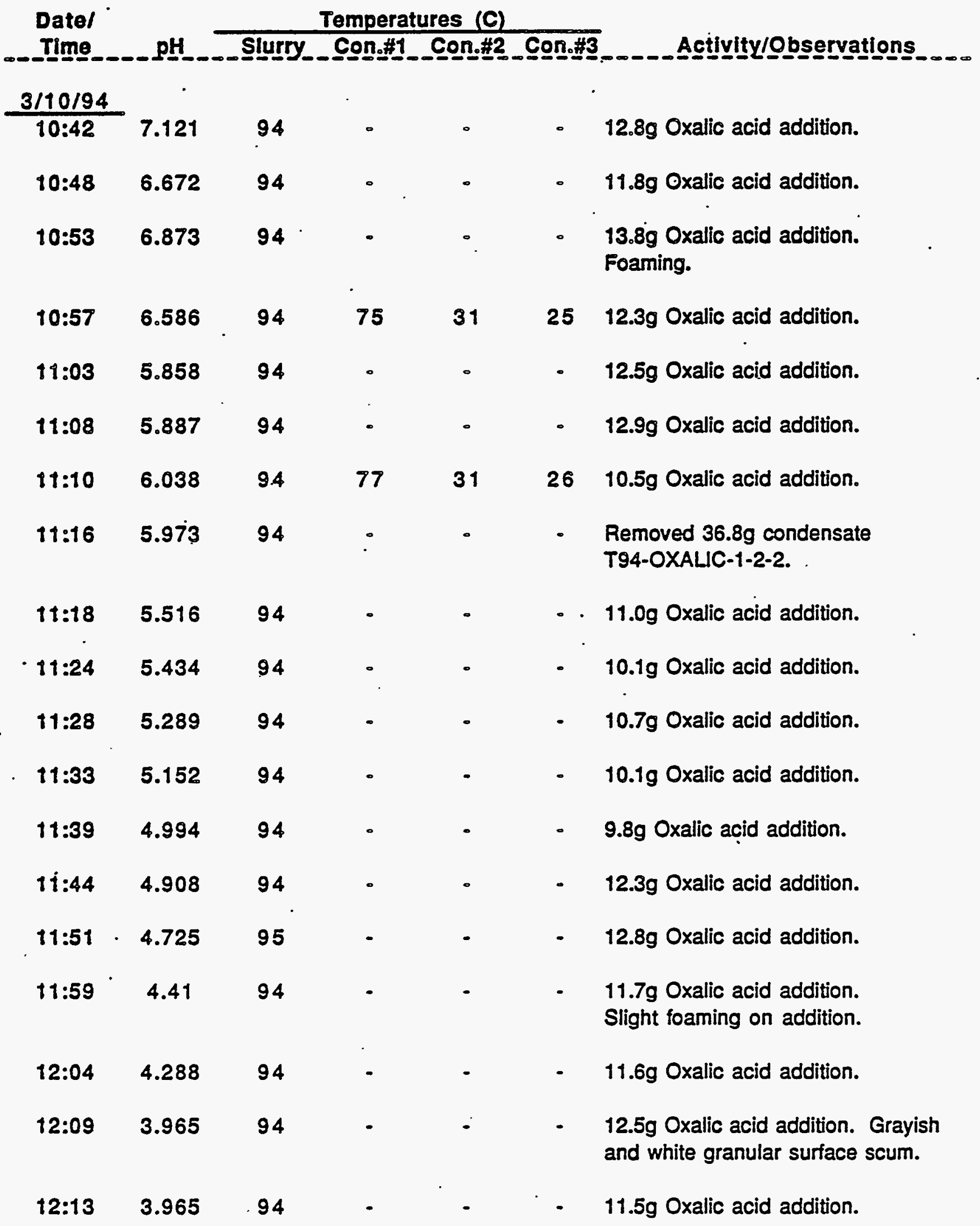




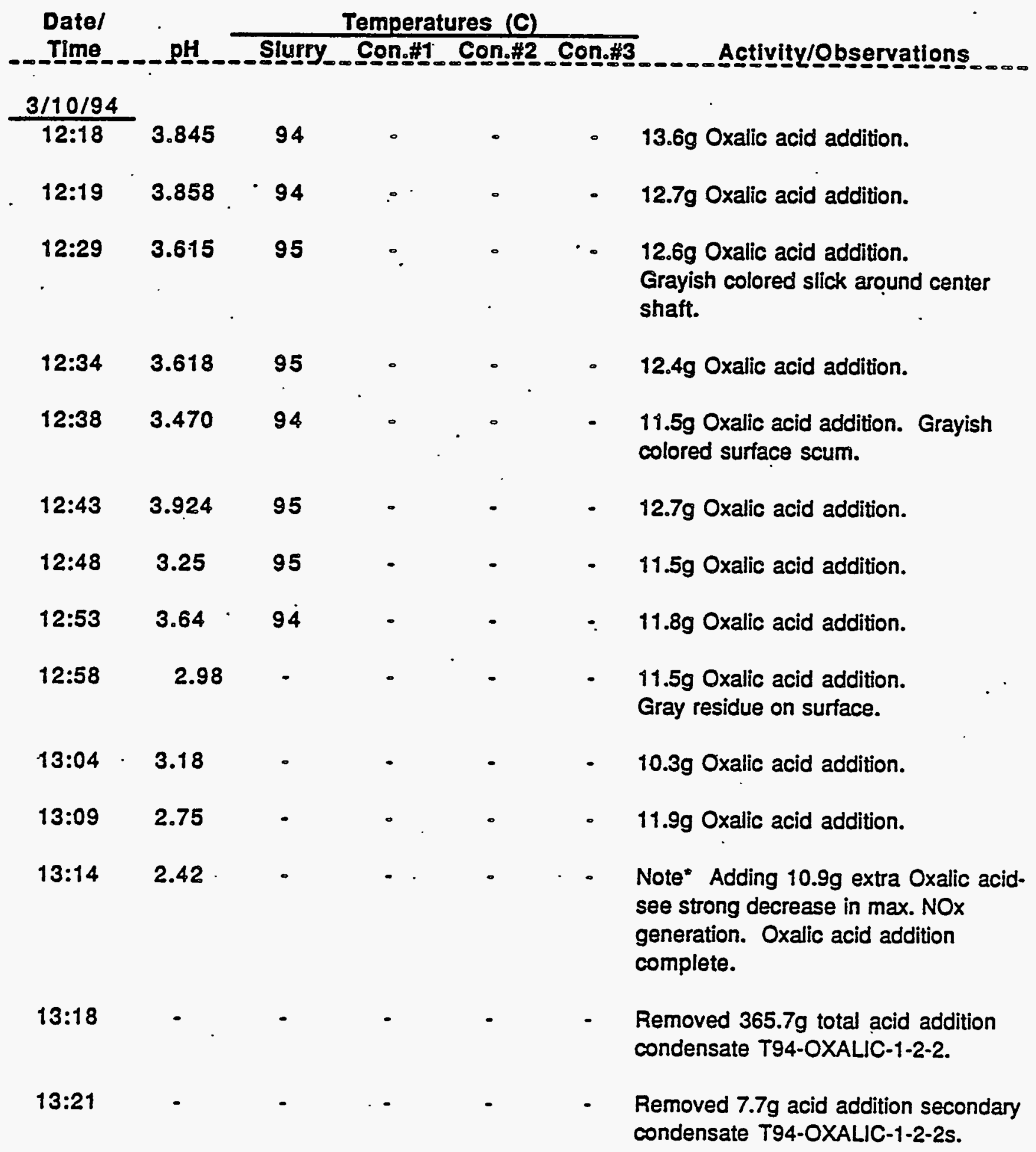




$$
\downarrow \text { ө6ed }
$$

-umosq 4s!̣əà6 жrep

әleusədns uo!̣eredəs әjeurədns

'Runis $\varepsilon-1-1-017 \forall \times 0-\$ 61$ -6u!nojos uәอ16 yrep

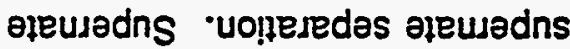

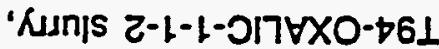

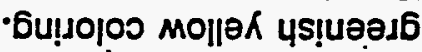
aleuradns uoinesedes ejeujadns

ISE! 'RAn|S $1-1-1-017 \forall \times 0-\nabla 61$ -reəjo sajdures әfesuapucos

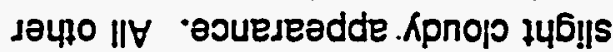

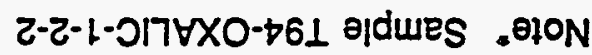

$$
\text { '\#० บ06ิษ }
$$

$0 \varepsilon: 9 !$

- $\varepsilon-1-1-017 \times 0-761$ Lunis uo!jenuasuos 'uo!!!ppe p!̣e łsod 66. Lᄂ panoway

•HO IE⿰H

$-2 \varepsilon-2-1-017 \forall \times 0-\triangleright 61$ өlesuәpuos kiepuosas uo!̣equesuos

'uon!ppe p!oe łsod $6 \angle L$ panoway

- $\varepsilon-\tau-1-017 \forall \times 0-\diamond 61$

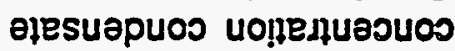

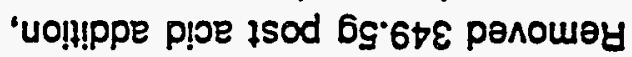

\section{'1еay paseวdou}

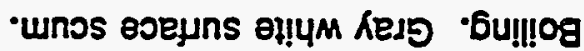

•p!n!I
$92 \quad 18$
98 oz:9เ

SL:SL

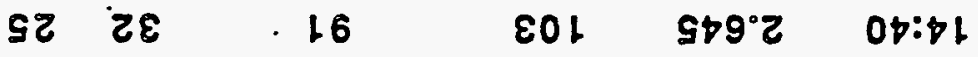

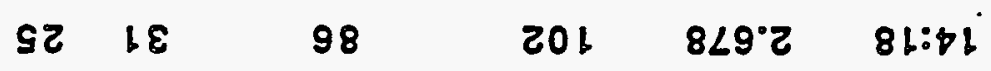

-sappred umodq yrep of xpejq

Ifews 'sojos umosq pes eldures

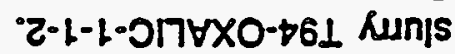

66. LL panouay 'rea4 paseadoul

$001 \quad 609^{\circ} \tau \quad \varepsilon \circ \varepsilon$

66 ๑9 $2 \quad Z \varepsilon: \varepsilon \downarrow$ 


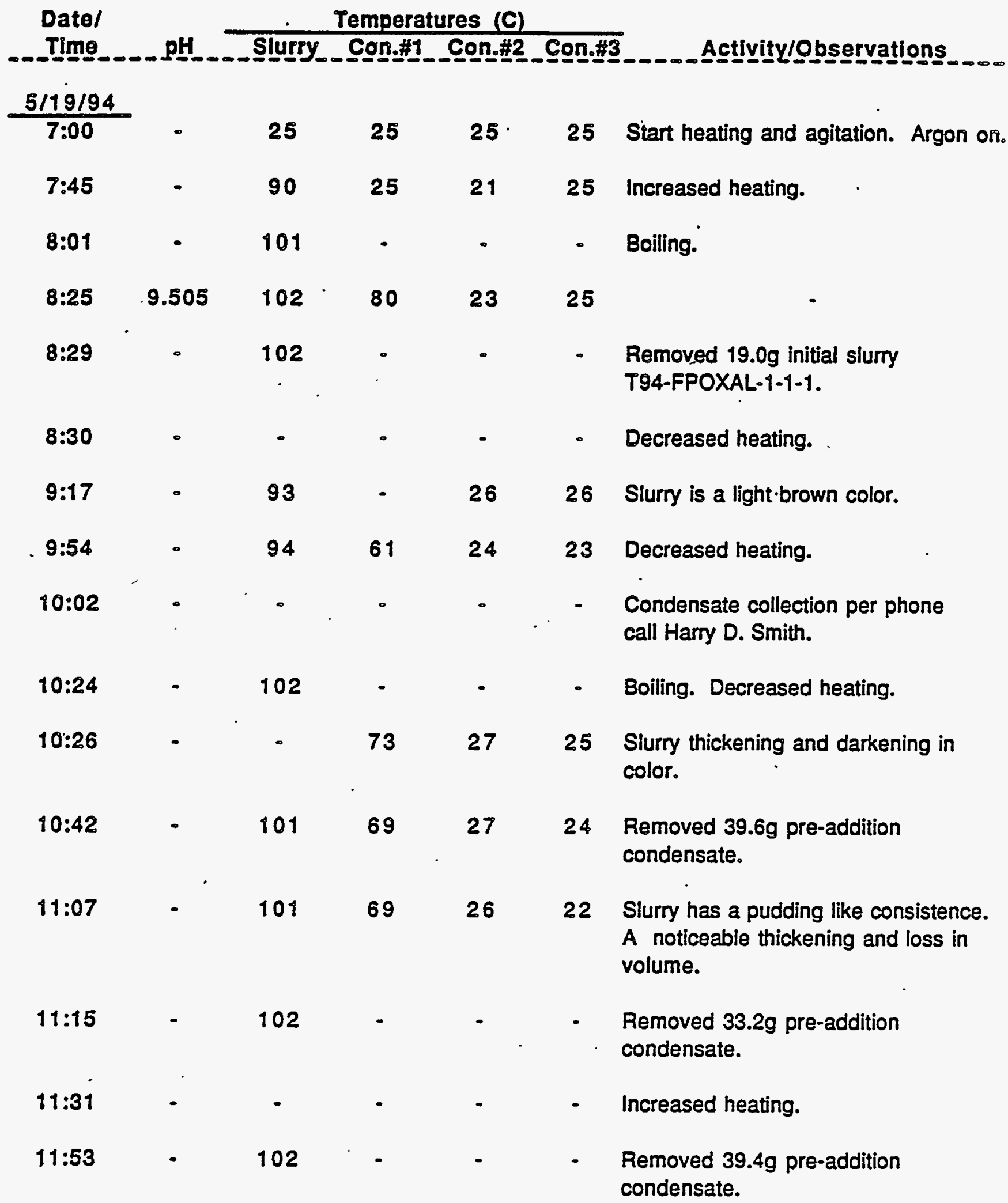




\begin{tabular}{|c|c|c|c|c|c|c|}
\hline \multirow{2}{*}{$\begin{array}{l}\text { Datei } \\
\text { Time }\end{array}$} & \multirow[b]{2}{*}{ pH. } & \multicolumn{4}{|c|}{ Temperatures (C) } & \multirow{2}{*}{ Activity/Observations } \\
\hline & & Slurry. & on.\#- & Con.\# & Con.\#3 & \\
\hline $5 / 19 / 94$ & $\cdot$ & & & & & \\
\hline $12: 15$ & - & - & - & - & - & $\begin{array}{l}\text { Removed } 37 \mathrm{~g} \text { pre-addition } \\
\text { condensate. }\end{array}$ \\
\hline $12: 35$ & - & 102 & 82 & 28 & 25 & $\begin{array}{l}\text { Removed } 39.9 \mathrm{~g} \text { pre-addition } \\
\text { condensate. Slurry appears to be } \\
\text { thicker than in previous tests. }\end{array}$ \\
\hline $12: 45$ & $\cdot$ & $\circ$ & $\cdot$ & - & - & Decreased heating. \\
\hline $13: 05$ & 9.054 & 93 & $\cdot$ & $\cdot$ & - & Add $10 \mathrm{ml}$ DIW with $0.2 \mathrm{~g}$ antifoam. \\
\hline $13: 10$ & - & - & - & 。 & - & Start Oxalic acid addition. \\
\hline $13: 12$ & $\cdot$ & $\cdot$ & - & - & - & 20.69g Oxalic acid addition. \\
\hline 13:23 & - & - & - & - & $\cdot$ & $11.9 \mathrm{~g}$ Oxalic acid addition. \\
\hline $13: 24$ & 8.739 & - & - & - & - & 9.7g Oxalic acid addition. \\
\hline $13: 34$ & $\therefore$ & - & - & - & - & 10.0g Oxalic acid addition. \\
\hline $13: 39$ & - & - & - & - & - & $\begin{array}{l}\text { Acid addition chamber plugged. } \\
\text { Unplugged chamber and added leftove } \\
\text { acid. }\end{array}$ \\
\hline $13: 49$ & - & - & - & 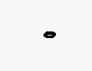 & - & 10.8g Oxalic acid addition. \\
\hline $13: 50$ & - & - & - & - & - & $12.0 \mathrm{~g}$ Oxalic acid addition. \\
\hline $13: 55$ & - & 94 & 56 & 24 & 23 & 10.8 Oxalic acid addition. \\
\hline $14: 00$ & - & - & - & - & - & 9.1g Oxalic acid addition. \\
\hline $14: 05$ & - & - & - & - & - & 10.0g Oxalic acid addition. \\
\hline $14: 10$ & 7.987 & - & - & - & - & $12.2 \mathrm{~g}$ Oxalic acid addition. \\
\hline $14: 17$ & 7.81 & - & - & - & - & $11.0 \mathrm{~g}$ Oxalic acid addition. \\
\hline $14: 21$ & - & - & - & - & - & 10.19g Oxalic acid addition. \\
\hline
\end{tabular}




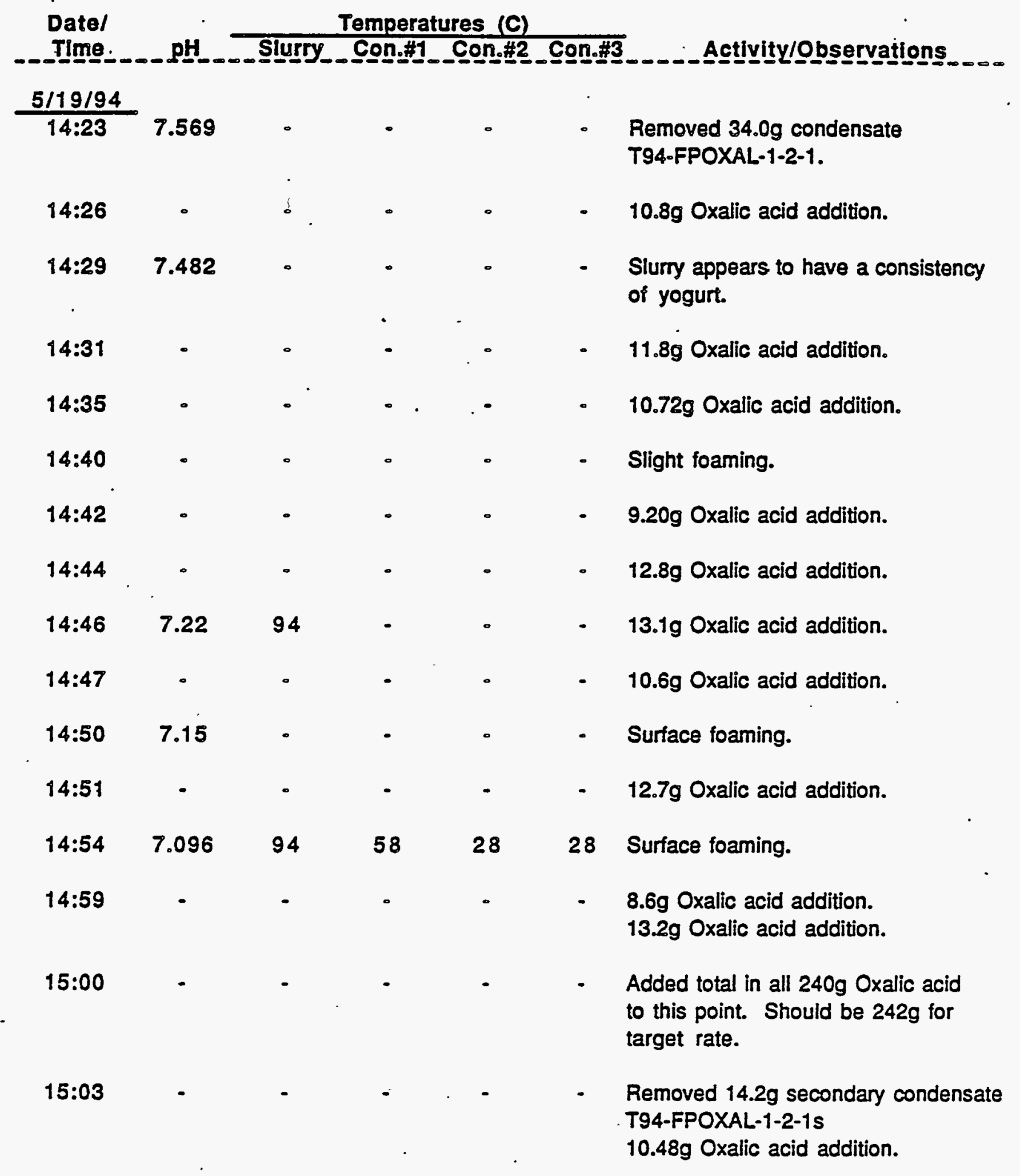




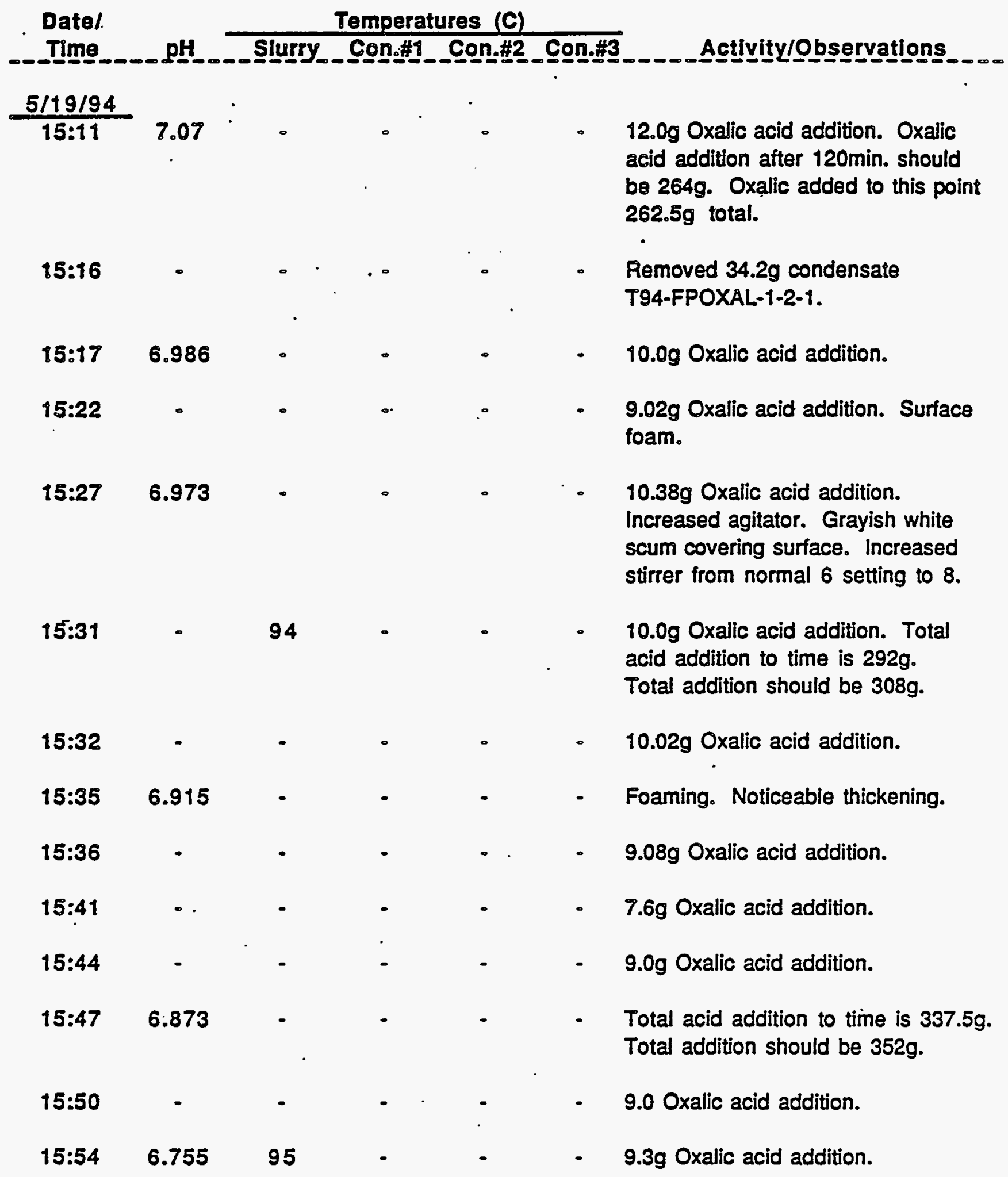




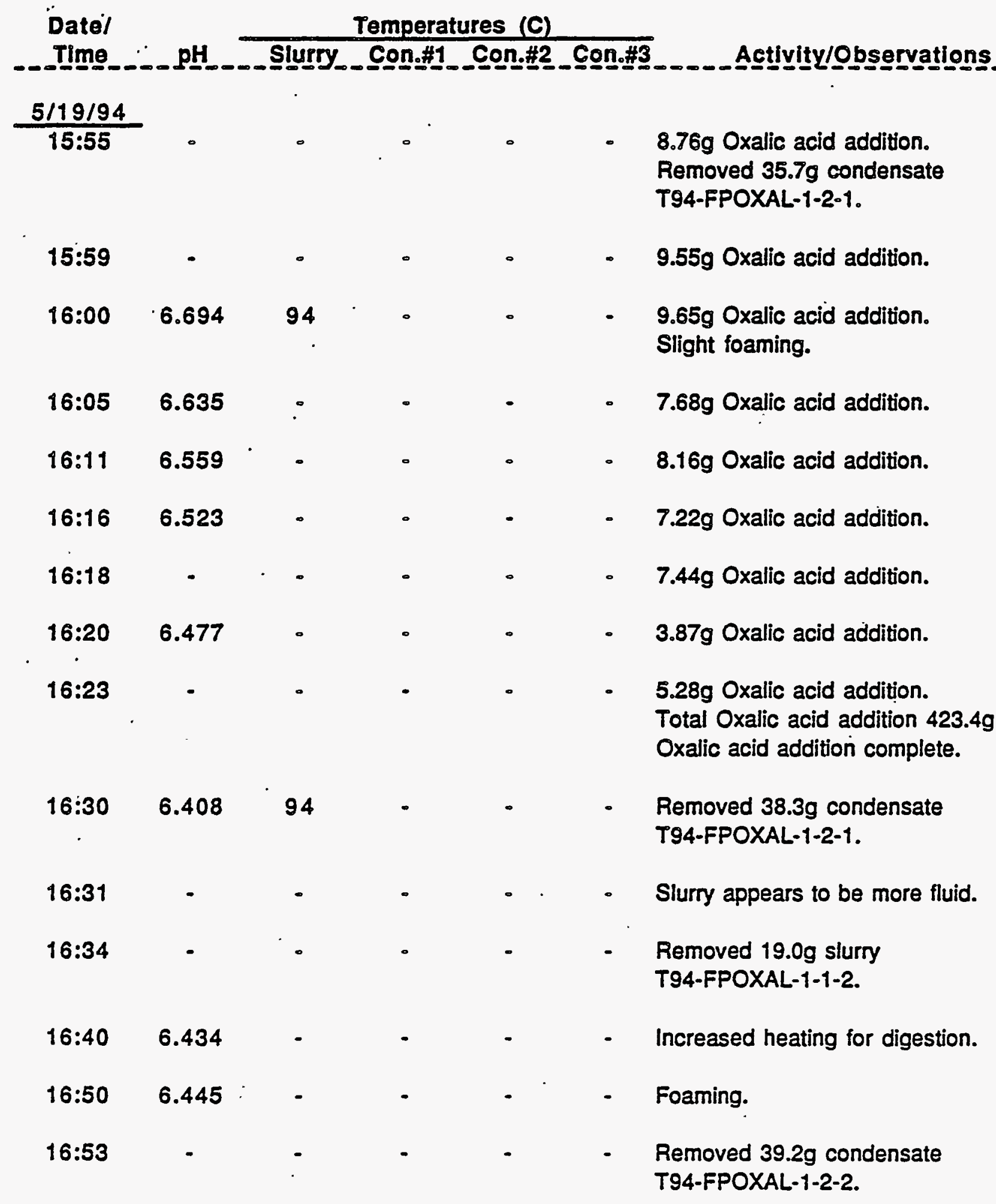


Activity Log - Test T94-FPOXAL-1

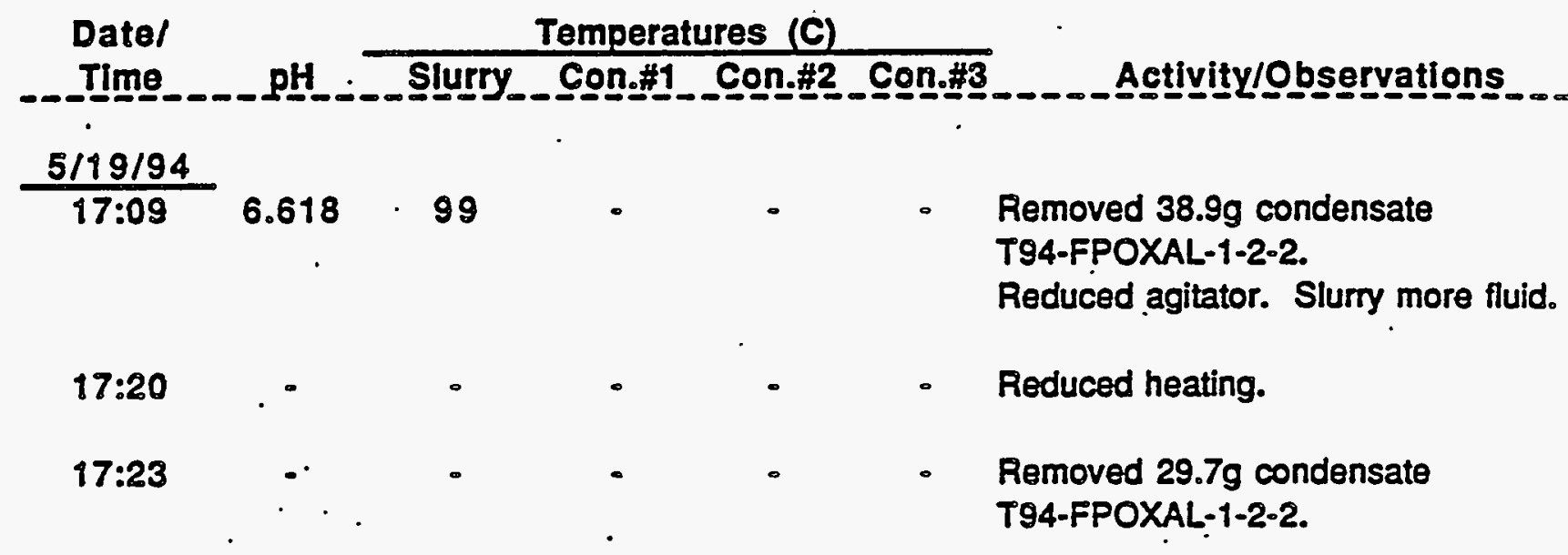

Page 6 


\section{Melter Feed and Condensate Composition}

The following tables summarize the results of the analyses of condensate and slurry samples taken during the slurry simulant processing into melter feed on the laboratory-scale. The time and date that the sample was taken is given by the activity log. The gWO/L and slumy density values allow the samples to be compared on the basis of a common $\mathrm{gWO} / \mathrm{L}$ value.

eWO/_and density- Density was determined from the weight of a known volume of slurry under ambient conditions and the $\mathrm{gWO} / \mathrm{L}$ was determined by firing the pre-weighed slurry to oxides in a furmace at $1050^{\circ} \mathrm{C}$ for two hours. The accuracy of these measurements is on the order of $2-3 \%$.

pHE.

The pH measurements were made at ambient conditions using calibrated pH sensing electrodes "Orion" (PNL-ALO-501 Rev.1). The accuracy of these measurements is better than $0.1 \mathrm{pH}$ unit.

Anions=

The anions were determined by ion chromatography using PNL-ALO212 Rev.l for the laboratory samples. The estimated accuracy is \pm 5 to $10 \%$.

Ammonia:

Ammonia is measured as the $\mathrm{NH}_{4}+$ ion with a standard ion electrode using procedure PNL-ALO-226 Rev.0. The accuracy is $\pm 15 \%$ for concentrations $<1 \mathrm{ppm}$. For concentrations $>1 \mathrm{ppm}$ the accuracy improves to $\pm 5 \%$. 


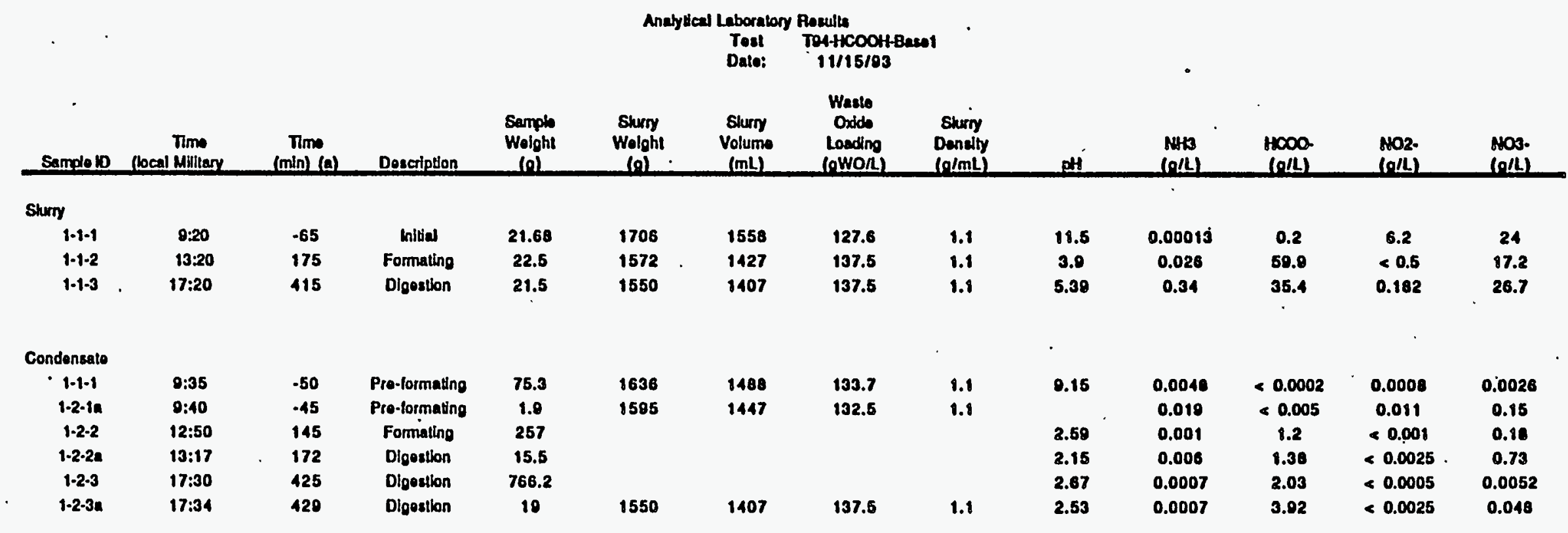

- minutos after acid addilion Initialod. 


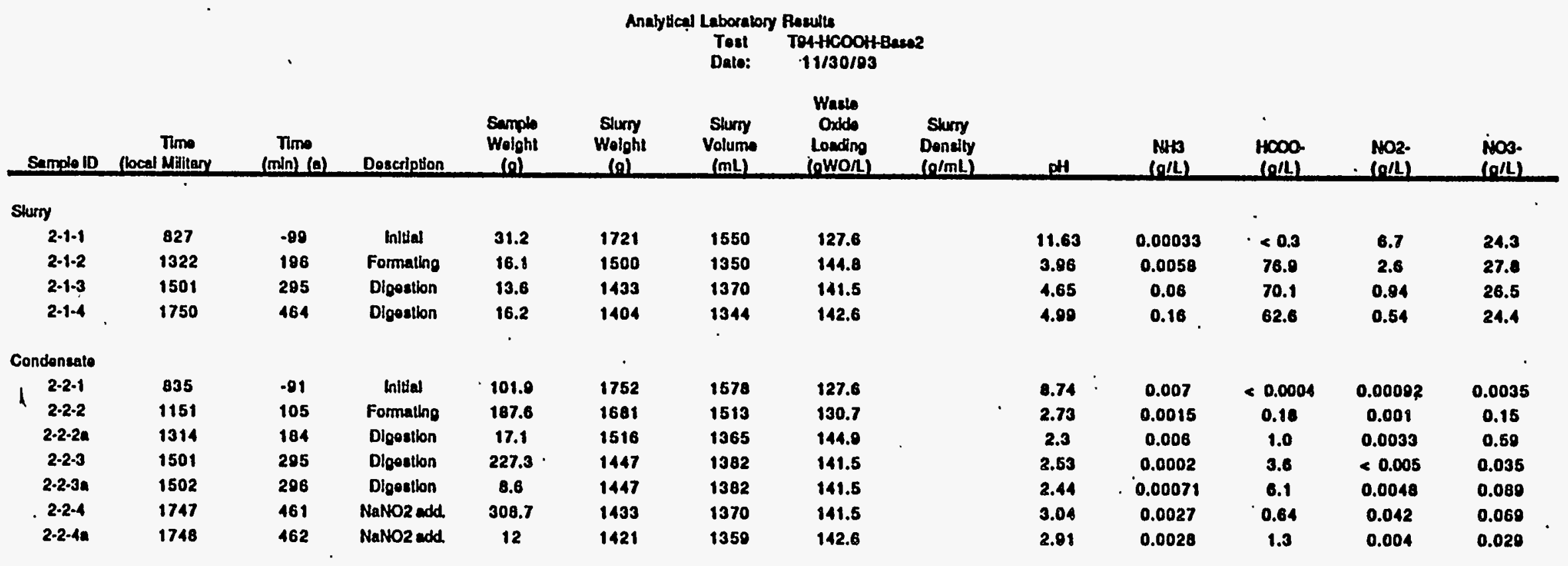

a minutos alter acid addilion inltiatod. 


\begin{tabular}{|c|c|c|c|c|c|c|c|c|c|c|c|c|c|}
\hline Sample lD & $\begin{array}{c}\pi_{m} \\
\text { flocal Military }\end{array}$ & $\underset{\substack{\min \\
(\ln )}}{(a)}$ & Doscription & $\begin{array}{l}\text { Serplo } \\
\text { Wolght } \\
\text { (g) }\end{array}$ & $\begin{array}{c}\text { Slury } \\
\text { Wolght } \\
\text { (o) }\end{array}$ & $\begin{array}{l}\text { I Laboralory } \\
\text { Tost } \\
\text { Dalo: } \\
\text { Stury } \\
\text { Volume } \\
\text { (ml) }\end{array}$ & $\begin{array}{l}\text { Rosults } \\
\text { TOA+HCOOH } \\
\text { 12/6/93 } \\
\text { Wasto } \\
\text { Oxids } \\
\text { Loading } \\
\text { (IwOn) }\end{array}$ & $\begin{array}{c}\text { Shury } \\
\text { Dondly } \\
\text { (o/mL) }\end{array}$ & pH & $\begin{array}{l}\text { NHW } \\
(01 L)\end{array}$ & $\begin{array}{l}8+\infty \\
(0 / L)\end{array}$ & $\begin{array}{l}\text { NO2- } \\
(0 / L)\end{array}$ & $\begin{array}{l}\mathrm{NOS}- \\
(\mathrm{Q} / L)\end{array}$ \\
\hline \multicolumn{14}{|l|}{ Shury } \\
\hline $3-1-1$ & 820 & -74 & Inittal & 14 & 1738 & 1565 & 127.6 & & 11.6 & 0.00032 & 2.6 & 6.1 & 22.5 \\
\hline $3-1-2$ & 1251 & 187 & Formating & 21.9 & 1509 & 1274 & 154.4 & & 4.23 & 0.027 & 83.1 & 0.093 & 29.3 \\
\hline $3 \cdot 1-3$ & 1430 & 296 & Digestion & 17.4 & 1687 & 1435 & 135.6 & & 4.7 & 0.074 & 72.7 & 0.98 & 26.8 \\
\hline $3.1-4$ & 1754 & 600 & Digestion & 10.6 & 1653 & 1405 & 136.7 & & 5.53 & 0.25 . & 68.6 & 1.1 & 46.3 \\
\hline \multicolumn{14}{|l|}{ Condensato } \\
\hline $3-2-1$ & 730 & -124 & Inittal & 67.2 & 1738 & 1665 & 127.6 & & 7.56 & 0.007 & 1.9 & 0.0012 & 0.0041 \\
\hline $3-2-2$ & 1246 & 102 & Formating & 202 & 1501 & 1340 & 148.1 & & 2.62 & 0.001 & 0.1 & 0.0027 & 0.94 \\
\hline $3-2.2 a$ & 1247 & 193 & Formating & 15 & 1531 & 1204 & 154.6 & & 2.28 & 0.006 & 0.14 & $<0.005$ & 0.6 \\
\hline $3-2-3$ & 1425 & 281 & Digeation & 117.7 & 1704 & 1451 & 135.6 & & 2.64 & 0.00048 & 2.6 & $<0.005$ & 0.024 \\
\hline $3-2-3 a$ & 1426 & 291 & Digestion & 5.1 & 1704 & 1451 & 135.6 & & 2.52 & 0.0014 & 5.0 & $<0.005$ & 0.12 \\
\hline $3-2-4$ & 1743 & 180 & HNOS add. & 372.6 & 1672 & 1422 & 136.8 & & 4.2 & 0.070 & 0.36 & 0.0067 & 0.01 \\
\hline \multirow[t]{2}{*}{$3 \cdot 2.4 a$} & 1747 & 403 & HNO3 add. & 14.7 & 1653 & 1405 & 136.7 & & 7.45 & 0.33 & 8 & 0.0047 & 0.03 \\
\hline & & & & & & & & & & & & ' & \\
\hline
\end{tabular}




\begin{tabular}{|c|c|c|c|c|c|c|c|c|c|c|c|c|c|}
\hline Sande iD & 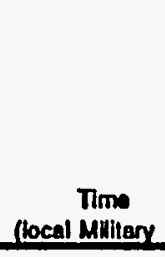 & $\underset{(\min )(a)}{\min }$ & Description & $\begin{array}{c}\text { Samplo } \\
\text { Wolght } \\
\text { (g) }\end{array}$ & $\begin{array}{l}\text { Surry } \\
\text { Wolght } \\
\text { (g) }\end{array}$ & $\begin{array}{l}\text { Laboralo } \\
\text { Tost } \\
\text { Dato: } \\
\text { Stury } \\
\text { Volumo } \\
\text { (mL) }\end{array}$ & $\begin{array}{l}\text { Reculls } \\
\text { TO4-Cltic-9 } \\
\text { 11/22/93 } \\
\text { Wasto } \\
\text { Oxido } \\
\text { Losding } \\
\text { (OWO/L) }\end{array}$ & $\begin{array}{l}\text { Shurry } \\
\text { Dencily } \\
\text { (o/mL) }\end{array}$ & ph & $\begin{array}{l}A+B \\
(0 / 1)\end{array}$ & $\begin{array}{c}\text { C6H5507. } \\
\text { (01L) }\end{array}$ & $\begin{array}{l}\text { NO2. } \\
\text { (o/ll) }\end{array}$ & $\begin{array}{l}\text { Nos. } \\
\text { (n/L) }\end{array}$ \\
\hline \multicolumn{14}{|l|}{ Slury } \\
\hline $1-1-1$ & 638 & .72 & Initial & 18.3 & 1654 & 1482 & 134.5 & & 11.66 & 0.0008 & $<0.5$ & 6.4 & 23 \\
\hline $1-1-2$ & 1320 & 210 & Cltric add. & 87.6 & 1424 & 1254 & 157 & & 3.16 & 0.03 & 10 & 0.27 & 23 \\
\hline $1-1-3$ & 1746 & 476 & Digestion & 15.1 & 1541 & 1372 & 142.1 & & 3.04 & 0.068 & 34 & 0.34 & 22 \\
\hline \multicolumn{14}{|l|}{ Condeneale } \\
\hline $1-2-1$ & 810 & .100 & miltial & 80 & 1672 & 1408 & 134.5 & 1.14 & 9.34 & 0.0074 & $<0.005$ & 0.0011 & 0.0038 \\
\hline $1-2-2$ & 1315 & 205 & Cltric idd. & 305.7 & & & & & 3.70 & -0.0003 & $<0.01$ & 0.002 & 0.006 \\
\hline $1-2-2 a$ & 1316 & 206 & Cltric add. & 16.0 & & & & & 3.83 & 0.008 & $<0.02$ & 0.0052 & 0.16 \\
\hline $1-2.3$ & $1735^{\circ}$ & 465 & Digestion & 776.7 & & & & & 3.88 & -0.0003 & $<0.01$ & 0.0011 & 0.038 \\
\hline $1-2-34$ & 1738 & 468 & Digostion & 10.6 & & & & & 4.00 & 0.0011 & $<0.05$ & 0.0038 & 0.024 \\
\hline
\end{tabular}

- minutos attor acid addilton Inlluatod. 
Analyited Laboralory Result

Tout To4-Glycolle-1

\begin{tabular}{|c|c|c|c|c|c|c|c|c|c|c|c|c|c|}
\hline Sample ID & $\begin{array}{l}\operatorname{Tim}_{\text {(bocal Milltary }} \\
\text { (2) }\end{array}$ & $\begin{array}{c}\operatorname{Tm} m \\
\langle\min \rangle(a)\end{array}$ & Description & $\begin{array}{c}\text { Samplo } \\
\text { Wolght } \\
\text { (R) }\end{array}$ & $\begin{array}{c}\text { Slurry } \\
\text { Woight } \\
\text { (g) }\end{array}$ & $\begin{array}{c}\text { Slury } \\
\text { Volume } \\
\text { (mL) }\end{array}$ & $\begin{array}{l}\text { Oxids } \\
\text { Loading } \\
\text { (gwor) }\end{array}$ & $\begin{array}{l}\text { Slurry } \\
\text { Donaly } \\
\text { (olmL) }\end{array}$ & pH & $\begin{array}{l}\text { NHB } \\
\text { (O/L) }\end{array}$ & $\begin{array}{c}\text { C2HoOs. } \\
\text { (a/L) }\end{array}$ & $\begin{array}{l}\mathrm{NO2}- \\
\text { (g/L) }\end{array}$ & $\begin{array}{l}103 . \\
(n / L)\end{array}$ \\
\hline Sturny & & & & & & & & & & & & . & \\
\hline $1-1-1$ & 852 & -8 & Initial & 15.6 & 1736 & 1564 & 127.6 & & 28.61 & 0.001 & 0.07 & 6.2 & 22.3 \\
\hline $1-1-2$ & 1205 & 185 & Glycollc add. & 17 & $\cdot 1533$ & 1380 & 143.1 & & 3.66 & 0.00019 & 107 & $<0.5$ & 26.7 \\
\hline $1-1-3$ & 1627 & 447 & Digostion & 13.7 & 1554 & 1400 & 138.8 & & 3.77 & 0.00010 & 114 & $<0.5$ & 29.8 \\
\hline \multicolumn{14}{|l|}{ Condensate } \\
\hline $1-2-1$ & 822 & -38 & Initial & 130.2 & 1736 & 1564 & 127.6 & & 8.0 & 0.0058 & 0.00078 & 0.00077 & 0.0026 \\
\hline 1-2-1a & 833 & -27 & Initial & 1.4 & 1738 & 1564 & 127.6 & & 0.10 & b.0045 & 0.10 & 0.0021 & 0.0024 \\
\hline $1-2-2$ & 1105 & 65 & Glycolic add. & 186.1 & 1550 & 1395 & 843.1 & & 2.27 & 0.0013 & 0.031 & 0.00058 & 0.63 \\
\hline 1-2-2a & 1210 & 180 & Dlgostion & 14.3 & 1518 & 1367 & 144.4 & & 1.35 & 0.005 & 0.2 & 0.0025 & 4.5 \\
\hline $1-2-3$ & 1554 & 114 & Digestion & 740.2 & 1554 & 1400 & 130.8 & & 3.18 & $<0.0001$ & 0.11 & $<0.0005$ & 0.044 \\
\hline $1-2-3 a$ & 1624 & 444 & Dlgostion & 17.9 & 1554 & 1400 & 139.8 & & 1.88 & 0.00038 & 0.25 & 0.0023 & 1.2 \\
\hline
\end{tabular}

a minutos after actd addition Inltiatod. 


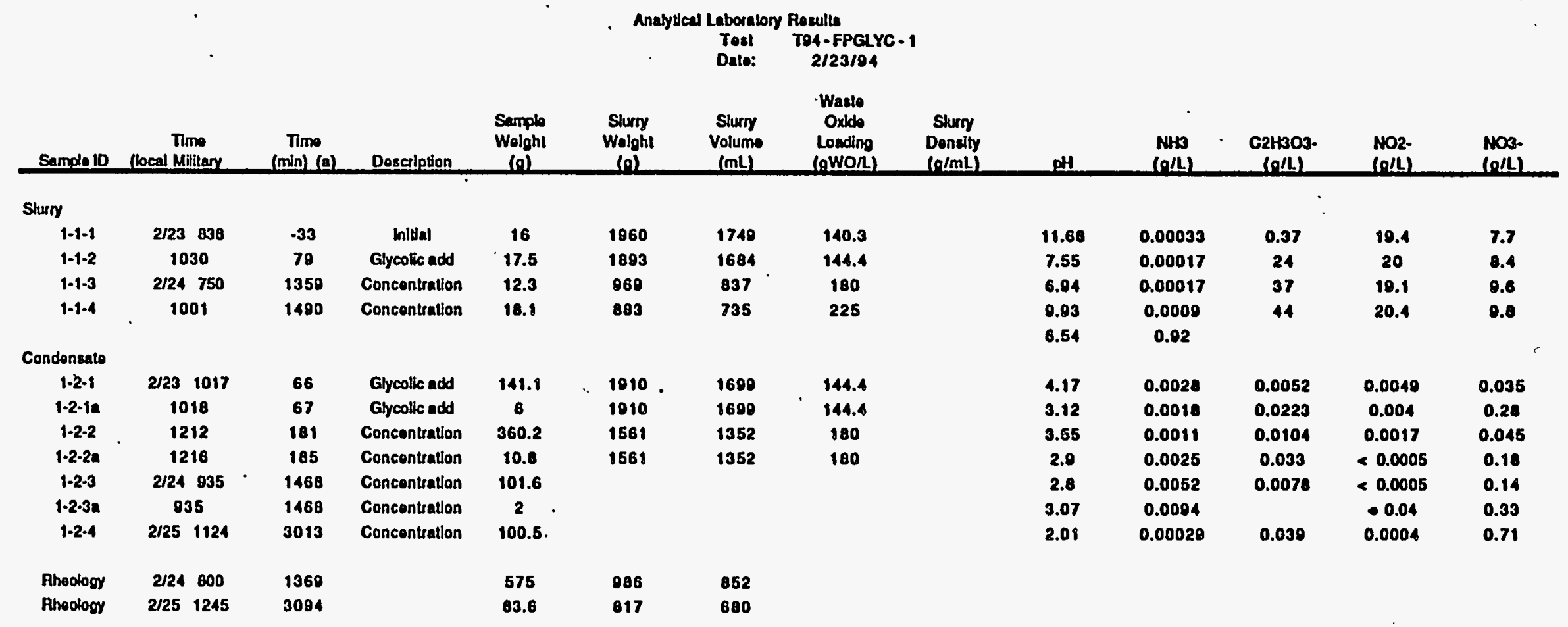

a minutos aftor acid addition inltiatod. 


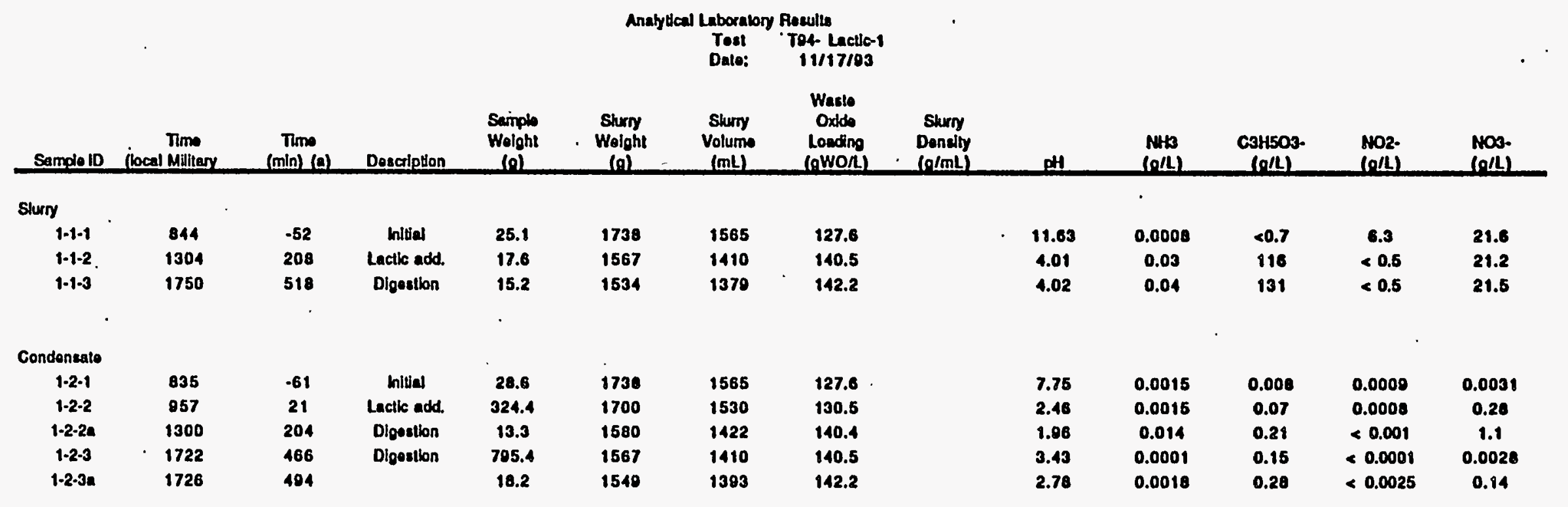

- minutes after acld addition initiatod. 


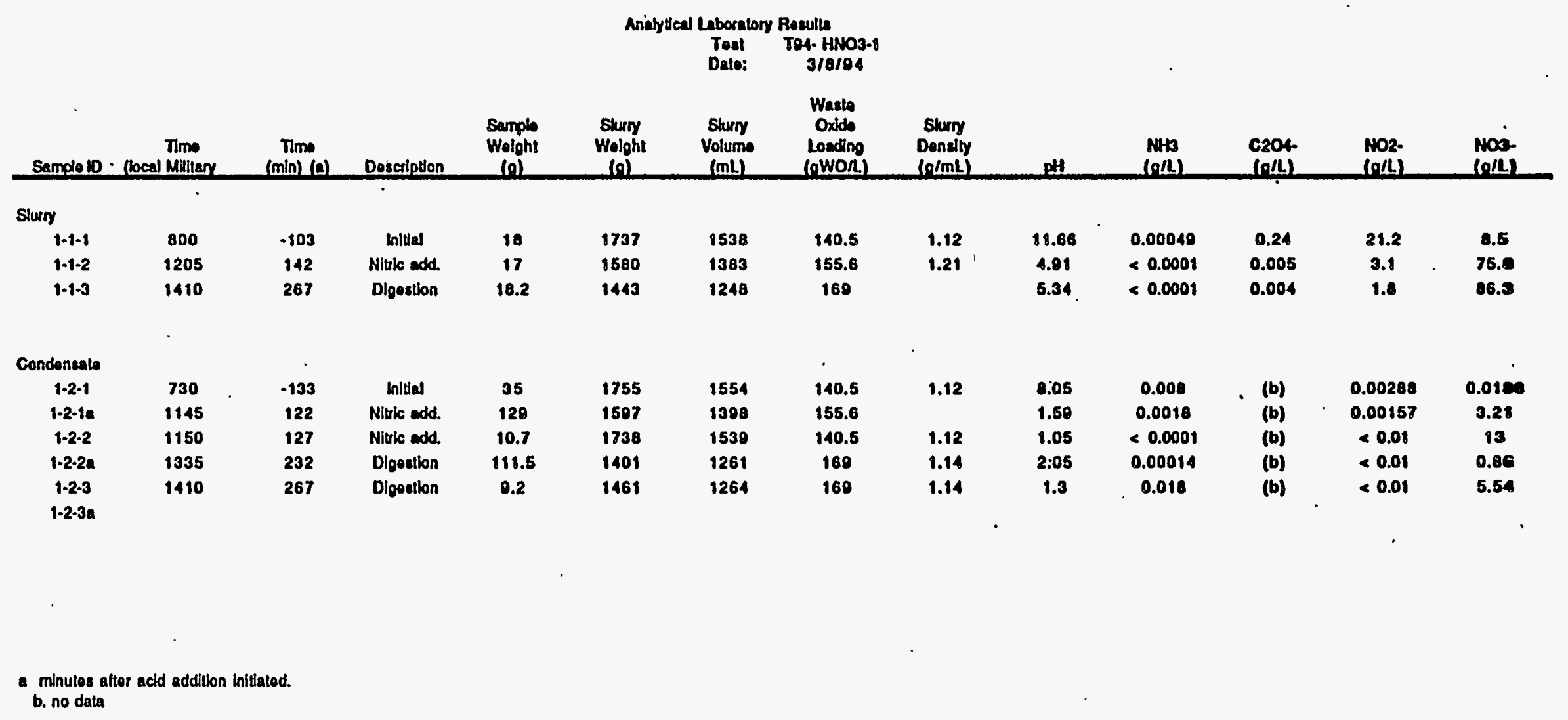




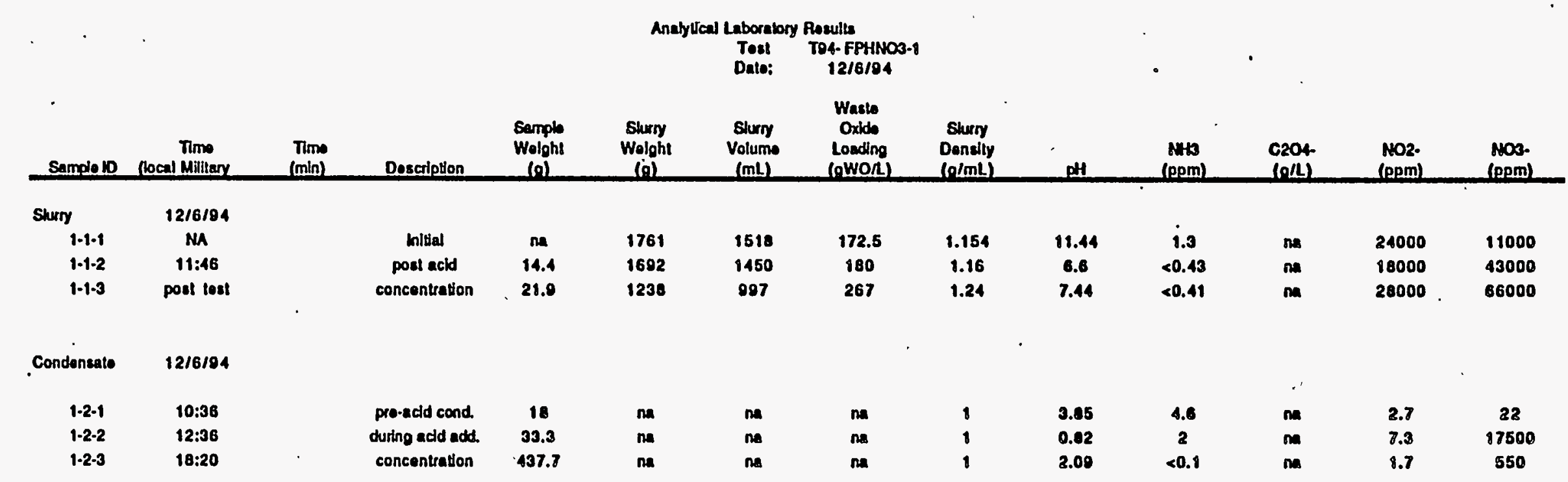




\begin{tabular}{|c|c|c|c|c|c|c|c|c|c|c|c|c|c|}
\hline \multirow[b]{2}{*}{ Sandeto } & & ' & & & Ana: & $\begin{array}{c}\text { cal Laborato } \\
\text { Tost } \\
\text { Dato: }\end{array}$ & $\begin{array}{l}\text { Results } \\
\text { To4-Oxallo-1 } \\
3 / 10 / 94\end{array}$ & & & & & & \\
\hline & $\begin{array}{l}\prod_{\text {local }} \\
\text { (lillary }\end{array}$ & $\prod_{(m)}$ & Description & $\begin{array}{c}\text { Sumplo } \\
\text { Wolght } \\
(9)\end{array}$ & $\begin{array}{c}\text { Sturny } \\
\text { Welght } \\
(0)\end{array}$ & $\begin{array}{c}\text { Sturny } \\
\text { Volumo } \\
-\quad \text { (mL) } \\
\end{array}$ & $\begin{array}{l}\text { Waste } \\
\text { Oxide } \\
\text { Loading } \\
\text { (owOL) }\end{array}$ & $\begin{array}{l}\text { Shury } \\
\text { Deneily } \\
\text { (o/mL) }\end{array}$ & $\mathrm{pH}(\mathrm{c})$ & $\begin{array}{l}\text { NHB } \\
(0 / L)\end{array}$ & $\begin{array}{l}\text { C2O4 } \\
\text { (nII) }\end{array}$ & $\begin{array}{l}\text { NO2. } \\
(0 / L)\end{array}$ & $\begin{array}{l}\text { Nos. } \\
\text { (OIL) }\end{array}$ \\
\hline \multicolumn{14}{|l|}{ Shurry } \\
\hline 1.1 .1 & 936 & .106 & Initial & 17 & 1604 & 1485 & 146 & & $11.18,11.74$ & 0.0026 & $<0.230$ & 25.5 & 8.7 \\
\hline $1-1-2$ & 1320 & 224 & Acld add. & 17 & 1505 & 1298 & 167 & & $3.57,3.55$ & $<0.0001$ & 25.0 & 0.6 & 15.4 \\
\hline $1-1.3$ & 1520 & 344 & Dlgestion & 17.1 & 1165 & 960 & 223 & & $3.64,3.42$ & $<0.2$ & 33 & 0.1 & 10.0 \\
\hline Condensate & & 。 & & & • & & & & & & & & \\
\hline $1.2-1$ & 735 & .121 & Inltial & 209.4 & 1711 & 1500 & 146 & & 8.92 & 0.0004 & 0.008 & 0.0028 & 0.0014 \\
\hline $1-2-2$ & 1310 & 222 & Acld add. & 102.6 & (b) & (b) & (b) & (b) & $8.85,1.48$ & 0.00038 & $<0.05$ & 0.058 & 2.01 \\
\hline $1-2.26$ & 1321 & 225 & Acld add. & 18.0 & 1523 & 1314 & 165 & & $8.40,0.04$ & 0.0084 & 0.1 & $<0.1$ & 8.6 \\
\hline $1-2-3$ & 1510 & 334 & Digestion & $340.5^{\circ}$ & (b) & (b) & (b) & (b) & $2.41,2.17$ & 0.00014 & $<0.08$ & $<0.01$ & 0.47 \\
\hline $1-2.38$ & 1510 & 334 & Digeation & 7.7 & 8183 & 946 & 210 & & $8.50,1.82$ & 0.0011 & $<0.1$ & $<0.8$ & 4.2 \\
\hline
\end{tabular}

a minutes aftor actd addition inltiated.

b. no data

c. two measurements mado in somo cases 


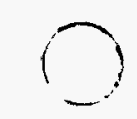

\section{Analylical Laboratory Routle}

Toul To4-FPOxal-1

\begin{tabular}{|c|c|c|c|c|c|c|c|c|c|c|c|c|c|}
\hline Sample fD & $\begin{array}{c}\text { Time } \\
\text { Llocal Militery }\end{array}$ & $\operatorname{Tim}_{(\min )(a)}$ & Description & $\begin{array}{c}\text { Samplo } \\
\text { Wolght } \\
(\rho)\end{array}$ & $\begin{array}{c}\text { Shurny } \\
\text { Wolght } \\
\text { (ด) }\end{array}$ & $\begin{array}{c}\text { Stury } \\
\text { Volume } \\
\text { (mL) }\end{array}$ & $\begin{array}{l}\text { Waste } \\
\text { Oxide } \\
\text { Loading } \\
\text { (qWOA) }\end{array}$ & $\begin{array}{l}\text { Slury } \\
\text { Density } \\
\text { (o/mL) }\end{array}$ & 새 & $\begin{array}{l}\text { SHtb } \\
(0 / L)\end{array}$ & $\begin{array}{l}\text { c204. } \\
\text { (0IL) }\end{array}$ & $\begin{array}{l}\text { NO2. } \\
(0 / 1)\end{array}$ & $\begin{array}{l}\text { NOS. } \\
(0 / 2)\end{array}$ \\
\hline \multicolumn{14}{|c|}{$5 / 19 / 94$} \\
\hline $1-1-1$ & 829 & -283 & Initial & 10 & 2164 & 1017 & 140 & 1.13 & 0.8 & 0.00025 & 0.46 & 20 & 7.7 \\
\hline \multirow[t]{2}{*}{$1-1.2$} & 1635 & 203 & post acid & 10 & 2100 & 1868 & 140 & 1.13 & 7.44 & $<0.000090$ & 55 & 13 & 10.4 \\
\hline & $\begin{array}{c}5 / 20 / 94 \\
840\end{array}$ & 1177 & concentration & 20.4 & 1564 & 1328 & 876 & 1.17 & 7.74 & $<0.00010$ & 63 & 10 & 18.6 \\
\hline Condeneate & $5 / 10 / 04$ & & & & & & & & & & & & \\
\hline 1-pre add & 1210 & .32 & pro-acld cond. & 180.1 & 1075 & 1728 & 153 & 1.14 & & & & & \\
\hline$\cdot 1-2 \cdot 16$ & 1316 & 3 & socondery cona & 14.2 & 2108 & 1882 & 112 & 8.13 & 1.40 & $\quad 0.0033$ & $<\mathbf{9 . 0 0 0 5}$ & 0.001 & 3.3 \\
\hline 1-2-1 & 1630 & 192 & during acld add. & 143 & 2128 & 1883 & 140 & 1.13 & 1.03 & 0.002 & $<0.0005$ & 0.001 & 2.2 \\
\hline \multirow[t]{2}{*}{$1-2 \cdot 2$} & 1723 & 251 & concentration & 107.8 & 2001 & 1758 & 140 & 1.13 & 2.86 & 0.0012 & $<0.00005$ & 0.00073 & 0.086 \\
\hline & $5 / 20 / 94$ & & & & & & & & & & & ' & \\
\hline 18 & 1247 & 1415 & socondary conc. & 14.65 & 1751 & 1508 & 174 & 8.16 & & & & & \\
\hline 1.cone & 1512 & 1620 & concentration & 423 & 1560 & 1318 & 198 & - 1.18 & & $\cdot$ & & & \\
\hline $1-2-3$ & 1528 & 1636 & concentration & 37.0 & 1513 & 1271 & 205 & 8.18 & 4.24 & 0.0026 & 0.00005 & 0.01 & 0.0016 \\
\hline
\end{tabular}

a minutos after acld addilion Inlllatod. 